\author{
UNIVERSIDADE DE SÃO PAULO \\ ESCOLA DE COMUNICAÇÕES E ARTES
}

TATIANA AOKI CAVALCANTI SILVA

Comunicação, alimentação e saúde: diretrizes para uma nova abordagem midiática e promoção da cidadania a partir da análise temática do material didático do Projeto Educando com a Horta Escolar (PEHE) 


\section{Comunicação, alimentação e saúde: diretrizes para uma nova abordagem midiática e promoção da cidadania a partir da análise temática do material didático do Projeto Educando com a Horta Escolar (PEHE)}

Dissertação apresentada ao Programa de Pós-Graduação em Ciências da Comunicação, Área de Concentração Estudo dos Meios e da Produção Midiática, Linha de Pesquisa Informação e Mediações nas Práticas Sociais, da Escola de Comunicações e Artes da Universidade de São Paulo, como exigência para obtenção do Título de Mestre em Ciências da Comunicação, sob a orientação da Profa. Dra. Alice Mitika Koshiyama. 
Autorizo a reprodução e divulgação total ou parcial deste trabalho, por qualquer meio convencional ou eletrônico, para fins de estudo e pesquisa, desde que citada a fonte.

Catalogação na Publicação

Serviço de Biblioteca e Documentação

Escola de Comunicações e Artes da Universidade de São Paulo

Dados fornecidos pelo(a) autor(a)

Silva, Tatiana Aoki Cavalcanti

Comunicação, alimentação e saúde: diretrizes para uma nova abordagem midiática e promoção da cidadania a partir da análise temática do material didático do Projeto Educando com a Horta Escolar (PEHE) / Tatiana Aoki Cavalcanti Silva. -- São Paulo: T. A. C. Silva, 2013.

166 p.: il.

Dissertação (Mestrado) - Programa de Pós-Graduação em Ciências da Comunicação - Escola de Comunicações e Artes / Universidade de São Paulo.

Orientadora: Alice Mitika Koshiyama

Bibliografia

1. Comunicação e alimentação I. Alice Mitika Koshiyama. II. Título.

CDD 21. ed. - 302.23 
Nome: AOKI, Tatiana

Título: Comunicação, alimentação e saúde: diretrizes para uma nova abordagem midiática e promoção da cidadania a partir da análise temática do material didático do Projeto Educando com a Horta Escolar (PEHE).

Dissertação apresentada à Escola de Comunicações e Artes da Universidade de São Paulo para obtenção do título de Mestre em Ciências da Comunicação.

Aprovado em:

Banca Examinadora

Prof. Dr.

Instituição:

Julgamento:

Assinatura:

Prof. Dr.

Instituição:

Julgamento:

Assinatura:

Prof. Dr.

Instituição:

Julgamento:

Assinatura: 
À minha avó, Teresa Sodeyama Aoki (em memória). 


\section{Agradecimentos}

Foram muitas as pessoas que me fizeram chegar aqui. A ideia inicial surgiu a partir da experiência de ter trabalhado com Lucilia Diniz, expert em nutrição e dieta. Continuei com a temática da pesquisa a partir da troca de ideias com minha amiga de infância, Beatriz Sabino.

Agradeço imensamente a oportunidade dada pela orientadora dessa dissertação, Profa. Dra. Alice Mitika Koshiyama, cujos encontros foram cruciais para as formulações práticas e teóricas.

Ao Programa de Pós-Graduação em Ciências da Comunicação (PPGCOM-USP), com destaque para Rosely Vieira de Sousa, por seu equilíbrio entre simpatia e profissionalismo.

Ao amigo de conversas e pedaladas, Akira Kojima, que me apresentou o autor Michael Pollan e suas novas visões sobre comida.

É com saudades que me despedirei do grupo de estudos "Jornalismo e a Construção da Cidadania”, sob a coordenação da Profa. Dra. Alice Mitika Koshiyama. A participação da orientadora, bem como de Ben-Hur Demeneck, Cristiane Reimberg, Davi Gentilli e Joana Tavares renderam muitas risadas, discussões e, por que não, compartilhamento de aflições.

À Profa. Dra. Ana Maria Cervato-Mancuso do Departamento de Nutrição da Faculdade de Saúde Pública (FSP-USP), que nos poucos meses em que participei de seu grupo de estudos em Segurança Alimentar e Nutricional (SAN), me permitiu compreender a importância de se ter uma equipe multidisciplinar para tratar de um tema tão complexo como alimentação.

Ao apoio de meus pais, Julia e Marcus, bem como de minha irmã, Juliana, pelo suporte e acompanhamento nesta jornada.

Agradeço ao amor de Bruno Lima, sempre gentil e disposto a me ajudar e aconselhar nas horas difíceis.

Agradeço também à ajuda de Augusto Veloso Leão, que entendia meus dilemas como um bom amigo e veterano de pesquisa. Ao César Jun Kita, por me proporcionar momentos de lazer em meio ao turbilhão da pesquisa e do trabalho.

Por fim, agradeço à instituição de ensino da Universidade de São Paulo (USP), que me proporcionou acesso a diversos aprendizados, não só para esta pesquisa, mas para a vida. 
Por que será que uma substância alimentar verdadeira precisa ter colorido diferente daquele que lhe é próprio?

Pompeo Amaral, do livro “Coma e Engorde”, de 1958. 


\section{Resumo}

AOKI, T. C. S. Comunicação, alimentação e saúde: diretrizes para uma nova abordagem midiática e promoção da cidadania a partir da análise temática do material didático do Projeto Educando com a Horta Escolar (PEHE). 2013. 167 f. Dissertação (Mestrado em Ciências da Comunicação) - Escola de Comunicações e Artes, Universidade de São Paulo, São Paulo.

A pesquisa objetiva fornecer diretrizes na abordagem da alimentação, de forma que se disponibilizem subsídios práticos a quem se propõe a tratar do tema e a ampliar o debate acerca do assunto.

Pode-se afirmar que as mídias que abordam dieta e nutrição baseiam-se no nutricionismo - a ideologia oficial da dieta ocidental - cujo foco é tratar o alimento como se ele fosse somente a soma de seus nutrientes, sempre sob aval do saber científico. A mídia também dispõe a alimentação como campo predominantemente voltado à dieta e nutrição, e constrói o discurso de que a alimentação do indivíduo e, por consequência, sua saúde, é uma responsabilidade individual e pouco vinculada a aspectos como à cultura e à política.

Na ausência de um veículo midiático que contrastasse com essa abordagem, foi adotado como objeto de estudo o material didático do Projeto Educando com a Horta Escolar (PEHE), que surgiu em 2005 e foi realizado pelo Fundo Nacional de Desenvolvimento da Educação (FNDE), em parceria com a Organização das Nações Unidas para a Agricultura e Alimentação (FAO). A metodologia do PEHE consiste em uma estratégia em Segurança Alimentar e Nutricional, de maneira que se efetivem os princípios do Direito Humano à Alimentação Adequada (DHAA) e da Soberania Alimentar. De caráter transdisciplinar, seu material comunicativo propõe a execução de uma horta comunitária, bem como um laboratório para abordar temas como saúde, nutrição e economia.

Como resultados são fornecidas 32 diretrizes na abordagem da alimentação, divididas em quatro temas centrais. No que concerne à análise do PEHE, foram detectadas seis temáticas centrais. E, tanto as diretrizes quanto a apreciação crítica do objeto se deram pelo método da análise temática, em conjunção com a pesquisa documental.

Pode-se afirmar que as diretrizes trazem à tona quanto o questionamento do tema alimento é intersetorial, político e, por consequência, de interesse público. E, ao tornarem públicas tais questões, os diversos setores envolvidos - sobretudo o Estado, a indústria alimentícia e o jornalismo - deverão rever suas políticas e estratégias em torno do alimento.

Palavras-chave: comunicação, cidadania, alimentação, saúde, promoção da saúde. 


\begin{abstract}
AOKI T. C. S. Communication, food and health: guidelines for a new media approach and promotion of citizenship from the thematic analysis of the didactic material of Project Educating with the School Garden. 2013. 167 f. Thesis (MA) - School of Communication and Arts, University of São Paulo, São Paulo, 2013.
\end{abstract}

The research aims to provide guidelines for food, in a way that provides practical subsidies to those who intends to address the issue as well as broaden the debate on the subject.

It can be stated that the media addressing diet and nutrition are based on nutritionism, the official ideology of the Western diet, which focuses on treating food as if it were only the sum of its nutrients, always under endorsement of scientific knowledge. The media also treat the subject as a field predominantly turned to diet and nutrition, based on the idea that the individual's food choices and, consequently, their health is an individual responsibility and less linked to other aspects, such as culture and politics.

In the absence of knowledge of a media vehicle that contrasted with that approach, it was adopted as object of study the Educating with School Garden Project (Pehe), which was released in 2005 and conducted by the National Fund for Education Development (FNDE) in partnership with the Food and Agriculture Organization of the United Nations (FAO). The methodology consists in a strategy in Food Safety, in a way that maintain the principles of the Right to Food and Food Sovereignty. This Project is trans disciplinary and proposes the implementation of a school garden as well as a laboratory to issues such as health, nutrition and economy.

As a result are provided 32 guidelines on food, divided into four main themes. Regarding the analysis of the Educating with School Garden Project, were detected six central themes. Both the guidelines and critical appreciation of the object is given by the method of thematic analysis, in conjunction with the documentary research.

The guidelines bring up the question of how much the theme food is intersectoral, political and therefore, public interest. And to make such issues public the various involved sectors - especially government, food industry and journalism - should review their policies and strategies around food.

Keywords: communication, citizenship, food, health, health promotion. 


\section{LISTA DE SIGLAS}

ABRASCO Associação Brasileira de Saúde Coletiva

CNAN Conferência Nacional de Alimentação e Nutrição

CONSEA Conselho Nacional de Segurança Alimentar

DHAA Direito Humano à Alimentação Adequada

DUDH Declaração Universal dos Direitos Humanos

EBIA Escala Brasileira de Segurança Alimentar e Nutricional

FAO Organização das Nações Unidas para a Agricultura e a Alimentação

FNDE $\quad$ Fundação Nacional para o Desenvolvimento da Educação

IBGE Instituto Brasileiro de Geografia e Estatística

ICNAN I Conferência Nacional de Alimentação e Nutrição

IDH Índice de Desenvolvimento Humano

INAN Instituto Nacional de Alimentação e Nutrição

IPEA Instituto de Pesquisa e Estatística Aplicada

MS Ministério da Saúde

OMS Organização Mundial da Saúde

ONGs Organizações Não governamentais

PEHE Projeto Educando com a Horta Escolar

PIDESC Pacto Internacional dos Direitos Econômicos, Sociais e Culturais

PNAN Política Nacional de Alimentação e Nutrição

PNEA Política Nacional de Educação Ambiental

PNSN Pesquisa Nacional sobre Saúde e Nutrição

SAN Segurança Alimentar e Nutricional

SISAN Sistema Nacional de Segurança Alimentar

WHO World Health Organization 


\section{Sumário}

1. Introdução 12

$\begin{array}{ll}\text { 1.1 Caminho metodológico percorrido } & 16\end{array}$

2. Cidadania e comunicação 20

$\begin{array}{ll}2.1 \text { Cidadania: principais conceitos } & 20\end{array}$

2.1.1 Os direitos de cidadania 21

2.1.2 Críticas ao modelo marshalliano de cidadania 22

2.1.3 Retóricas contrárias aos direitos humanos 28

2.1.4 Marcos históricos dos direitos do homem 32

2.2 A construção da cidadania no Brasil 36

2.3 A informação como promotora da cidadania 41

2.3.1 Sociedade de grupos x sociedade de massas 42

2.3.2 Informação como valor para a cidadania 46

2.4 Cidadania: dada de forma permanente, no cotidiano 53

3. Comunicação e saúde 58

3.1 Promoção da Saúde: princípios e contextos 58

3.1.1 Promoção da Saúde e qualidade de vida 58

3.1.2 Contexto histórico da Promoção da Saúde 60

3.1.3 Políticas públicas e qualidade de vida 62

3.2 Saúde coletiva: saúde, sociedade $\quad 64$

3.3 Comunicação e saúde na promoção da cidadania 67

3.4 Modelo de comunicação para políticas públicas 68

3.4.1 Comunicação e políticas públicas para saúde: processos 69

3.4.2 C\&S: relações de poder e SUS como princípio norteador $\quad 70$

3.4.3 Comunicação e Saúde: emergência de novos sentidos e usos 77

3.5 Como os meios de comunicação retratam a saúde? 80

3.6 Comunicação e saúde: o que estamos discutindo? 83

4. Alimentação e Comunicação $\quad 86$

4.1 Segurança Alimentar e Nutricional: conceitos 86

$\begin{array}{lll}\text { 4.1.1 Contexto histórico da SAN } & 91\end{array}$ 
4.1.2 Brasil: um Guia Alimentar para sua população 95

4.2 Mídia e Alimentação: dilemas da dieta ocidental 99

4.2.1 Cultura alimentar e comida processada 100

4.2.2 Nação fast food versus Orgânicos: qual a real diferença? 103

4.2.3 Alimentação: como mudar o cenário atual 105

4.2.4 Nutricionismo: a ideologia da dieta ocidental 108

4.3 Políticas públicas para alimentação saudável 110

4.4 Diretrizes para alimentação 112

4.5 Alimentação: precisa ser um dilema? 121

5. Material didático do Projeto Educando com a Horta Escolar 124

5.1 O Projeto Educando com a Horta Escolar 124

5.2 PEHE: descritivo do material didático 128

5.2.1 Caderno 1- A Horta Escolar dinamizando o currículo da escola 129

5.2.2 Caderno 2 - Orientações para implantação e implementação de horta escolar 136

5.2.3 Caderno 3 - Alimentação e nutrição: caminhos para uma vida saudável 138

5.3 Material didático: apreciação crítica 144

6. Considerações finais 152

7. Referências bibliográficas 154

$\begin{array}{ll}\text { 8. Anexos } & 159\end{array}$ 


\section{Introdução}

O presente trabalho pressupõe que o tema da alimentação integra, acima de tudo, um processo educativo. Pode-se também afirmar uma intersetorialidade da questão, isto é, não se analisa o alimento somente pelo ponto de vista da ciência e da saúde, mas também de política, cultura, meio ambiente. Nesse sentido, a maneira como o indivíduo se alimenta não é baseada apenas em escolhas individuais e em estilo de vida: ao contrário, tem mais a ver com as condições socioeconômicas, culturais, bem como com seu relacionamento nas intervenções governamentais e na sociedade civil.

O panorama observado na relação entre mídia e alimentação constitui-se em um aumento substancial da quantidade de cadernos de saúde e nutrição, de revistas exclusivas sobre dieta e emagrecimento, de programas televisivos de bem-estar, assim como o crescente destaque sobre o assunto nos principais veículos de mídia nacional. Tal crescimento também responde a um aumento do interesse do público a respeito da alimentação, nutrição e dietética. E, embora as críticas a esse tipo de cobertura já existam dentro da academia, pouco foi sugerido para aperfeiçoar o estilo das pautas, com diretrizes práticas aos comunicadores e a quem se propõe a tratar do tema.

Essas questões, somadas à experiência pessoal e profissional da pesquisadora em publicações midiáticas na área de alimentação, nutrição e dietética, deram origem a esta pesquisa. Na atuação profissional, pode-se destacar a produção de conteúdo e de pesquisas em dieta e nutrição por Lucilia Diniz, entre 2009 e 2010. No período, atuou nas seguintes mídias: produção de seu reality show sobre dieta e emagrecimento na Rede TV; pesquisa e produção de suas colunas nas revistas BOA FORMA, CONTIGO! e MEN'S HEALTH (Editora Abril); revista da Drogaria Iguatemi; site Good Light; programa na Rádio Globo.

A partir de 2010, na Editora Abril, também atuou em publicações voltadas ao público feminino, como portal MdeMulher ${ }^{1}$ - O portal da MULHER BRASILEIRA, CAPRICHO, GLOSS, BOA FORMA e Pensou Mulher, Pensou Abril, este um projeto da Abril Mídia* Além disso, desde 2009, é uma das coordenadoras do projeto Frugalidade, que aborda uma nova visão a respeito da alimentação. E, em 2011, foi jornalista responsável pelo lançamento da revista Nutrir+, cujo conteúdo é elaborado por nutricionistas.

Para o trabalho, utilizava-se como fonte de pesquisa veículos midiáticos, provenientes de vários locais do mundo, que adotavam abordagens similares a respeito da alimentação, frequentemente atribuindo os problemas de saúde advindos da dieta como responsabilidade

\footnotetext{
${ }^{1}$ O Portal MdeMulher está disponível em: <http://mdemulher.abril.com.br/>.
} 
individual. Também se notou a ausência de conceitos como a segurança alimentar, as condições político-sociais, que intervinham na dieta, e as características culturais dos hábitos alimentares. Somadas a isso, as pautas eram baseadas em regras e diretrizes que mudam a cada edição. Por exemplo: em uma edição, os carboidratos fazem mal e, na seguinte, é benéfico à saúde. O mesmo ocorre com gorduras, proteínas etc., gerando um círculo vicioso que aumenta a confusão por parte do receptor da informação.

Outro ponto que merece ser destacado se deu pela experiência pessoal, quando a pesquisadora atuou como correspondente internacional no Japão. O país conta com as menores taxas de obesidade entre os países desenvolvidos e possui variadas políticas públicas para a promoção da saúde e da saúde preventiva. A vivência no exterior possibilitou o entendimento proposto por Minayo (1992, p. 176) de que “cada sociedade tem um discurso sobre saúde/doença, sobre o corpo, que corresponde à coerência ou às contradições de sua visão de mundo e de sua organização social,” trazendo à tona a necessidade de uma nova abordagem sobre alimentação.

Entretanto, após exaustiva pesquisa, não foi encontrado um meio comunicativo que propusesse uma forma diferente de tratar da alimentação e que fornecesse, em suas pautas, noções de Segurança Alimentar e Nutricional (SAN), bem como levassem os indivíduos à ação para que reivindicassem o Direito Humano à Alimentação Adequada (DHAA) e à Soberania Alimentar.

Na ausência dessa fonte, adotou-se como objeto de estudo o material didático do Projeto Educando com a Horta Escolar (PEHE), que surge como estratégia em segurança alimentar e nutricional, por meio de uma proposta transdisciplinar de educação para a cidadania. O projeto possui subsídios teóricos, resultado de uma cooperação internacional entre a FAO e o FNDE, que devolve à sociedade os “[...] frutos do investimento de recursos públicos brasileiros” (PROJETO EDUCANDO COM A HORTA ESCOLAR, 2010, p. 136).

O PEHE utiliza a horta como eixo gerador de outras discussões, e vale-se do material didático para professores e alunos, bem como do acompanhamento dos processos por parte da organização e dos conselheiros do projeto. Apontado como eixo conceitual e metodológico do Projeto Educando com a Horta Escolar (2010), o material aponta alternativas para a alimentação e suas implicações por meio da horta, atuando como um possível laboratório de discussão intersetorial e de ideias de políticas públicas em segurança alimentar e nutricional.

O PEHE coloca-se também como elemento de prática pedagógica de três temas principais, que são: educação/currículo, alimentação/nutrição e meio ambiente/hortas 
escolares (PROJETO EDUCANDO COM A HORTA ESCOLAR, 2010). Além disso, incentiva a inclusão da comunidade que circunda a escola, seja de funcionários, familiares, seja de profissionais da agricultura familiar, sob a proposta de fortalecer a cultura regional e ampliar a prática pedagógica, possibilitando mudanças ainda maiores na cultura alimentar, educacional e ambiental.

Todo o conceitual teórico e metodológico do projeto (PROJETO EDUCANDO COM A HORTA ESCOLAR, 2010, p. 32) encontra-se no objeto de estudo adotado, ou seja, no material didático, que consiste em três cadernos para docentes e os dois cadernos para discentes $^{2}$. Nos cadernos são elencados não só a execução da horta, mas também uma discussão em torno de temas como alimentação, saúde, meio ambiente, educação, com atividades intra e extraclasse. Após a leitura detida dos cadernos para docentes, bem como do caderno intitulado "Mapeamento do Processo", que explica como se deu a implantação do PEHE, selecionou-se o material didático do PEHE como objeto de pesquisa.

Existem outros projetos que também propõem uma nova forma de enxergar o alimento. Um dos mais conhecidos é o da associação internacional Slow Food, que surgiu na Itália, em 1989, e que se coloca como um contraponto ao fast food e à alimentação sustentável. Também promove a apreciação da culinária regional e da ecogastronomia, tópicos também encontrados no PEHE, principalmente após a reformulação do projeto, que se retomará em 2012. Contudo, pelo seu caráter mundial, o Slow Food já contempla maior divulgação, tanto na academia quanto nos meios de comunicação. Portanto, optou-se por adotar um objeto de pesquisa que fora pouco divulgado.

Para a pesquisa, adotou-se como método a pesquisa documental (ECO, 1996; GIL, 2010), dividida em quatro temáticas principais, que são: cidadania, comunicação, saúde e alimentação, tendo a comunicação como ponte de conexão com os demais temas, visando à interdisciplinaridade. Com base no referencial teórico adquirido, são elencadas 32 diretrizes na abordagem da alimentação, elemento central de todo o trabalho, divididas em quatro temas centrais. No que concerne à análise do PEHE, foram detectadas seis temáticas centrais. Tanto as diretrizes quanto a apreciação crítica do objeto se deram pelo método da análise temática, em conjunção com a pesquisa documental (ECO, 1996; GIL, 2010; MINAYO, 1992).

Assim, para a discussão teórica da primeira temática, cidadania, tem-se como norte os pensamentos da filósofa Heller (2008), bem como os de Hirschman (1992) e Bobbio (1992), entre outros autores. Os três consideram que as grandes mudanças não se dão necessariamente de maneira abrupta, mas, sim, como um processo contínuo e dado no cotidiano. Já a

\footnotetext{
${ }^{2}$ Estes, divididos por faixa etária de 6 a 10 anos e de 11 a 14 anos.
} 
comunicação é, conforme aponta Gentilli (2005), um direito-meio, ou seja, um direito que viabiliza o exercício dos demais direitos do homem - direitos civis, políticos e sociais. Tal importância se dá porque, em uma sociedade democrática, se os direitos de cidadania e os procedimentos democráticos são dispostos ao indivíduo de maneira mediada, é a informação que possibilita ter conhecimento de seus direitos para que se possa reivindicar por eles.

No que tange ao assunto da saúde coletiva, parte-se do princípio da Promoção da Saúde, movimento que articula a saúde não só como uma questão individual, do corpo, mas integrada a outros sistemas, como o meio ambiente, bem-estar e sociedade (COSTA, 2011). Para o tema, são adotados os autores: Westphal (2007), Mendes (2007), Bógus e Westphal (2007) e Fernandez e Mendes (2007). E, na conexão entre Comunicação e Saúde, adotam-se, sobretudo Araújo e Cardoso (2007), bem como Bueno (1996).

A temática da alimentação vale-se das noções de Segurança Alimentar e Nutricional (SAN), que abrangem o direito ao alimento em quantidade e qualidade suficientes (CONSEA, 2010). Nesse sentido, tem-se que o conceito de SAN também vai além do acesso ao alimento: integra principalmente a realização desse direito, de maneira que aponte para a necessidade de uma intervenção política e social.

E, na relação entre comunicação e alimentação, a principal referência é Pollan (2007, 2008, 2010), jornalista que critica o nutricionismo - a ideologia da dieta ocidental -, que consiste em utilizar do aval científico para pensar o alimento, levando em conta somente suas propriedades nutricionais. Nesse tópico, serão tratadas as origens do nutricionismo, as consequências da adoção dessa ideologia por parte dos veículos midiáticos e, finalmente, as diretrizes em alimentação.

Em seguida, será apresentado o Projeto Educando com a Horta Escolar (PROJETO EDUCANDO COM A HORTA ESCOLAR, 2010), que trata detalhadamente do projeto descritivos do material didático para docentes, bem como a análise temática do material.

Nas Considerações Finais, a discussão apresenta um balanço do trabalho, além de perspectivas de futuros estudos. Por fim, no Anexo, há uma listagem de instituições e órgãos vastamente mencionados ao longo da dissertação.

Espera-se que o trabalho proporcione um debate significativo para um tema tão contemporâneo como a alimentação, de maneira que consiga modificar opiniões e enriquecer a democracia. 


\subsection{Caminho metodológico percorrido}

Para os procedimentos metodológicos, foi adotado como fonte principal o livro "O Desafio do conhecimento: pesquisa qualitativa em saúde”, de Minayo (1992). A obra articula a pesquisa qualitativa no campo das Ciências Sociais em Saúde e situa que o objeto das Ciências Sociais é essencialmente qualitativo, pois “é complexo, contraditório, inacabado, e em permanente transformação” (MINAYO, 1992, p. 22).

A autora acredita que metodologia consiste no “[...] caminho e o instrumental próprios da abordagem da realidade, isto é, o próprio processo de desenvolvimento das coisas” (MINAYO, 1992, p. 22). Também, com base em Minayo (1992), foi adotada a abordagem da hermenêutica dialética, que se apresenta como um caminho do pensamento, como "uma via de encontro entre ciências sociais e a filosofia” (MINAYO, 1992, p. 218). Por hermenêutica, entende-se a explicação e interpretação de um pensamento, e tal abordagem foi selecionada porque traz, para o primeiro plano no tratamento dos dados, “[...] as condições cotidianas da vida e promove o esclarecimento sobre as estruturas profundas desse mundo do dia a dia” (MINAYO, 1992, p. 219-221). A menção a esses pressupostos metodológicos se faz necessária para o trato do material comunicativo, a fim de aclarar, ao próprio pesquisador, o contexto dos documentos a serem analisados (MINAYO, 1992).

Além do referencial de Minayo (1992), também é adotada a pesquisa documental qualitativa, baseada nos procedimentos de Eco (1996) e Gil (1991). O referencial teórico se concentrará nos seguintes assuntos: comunicação, cidadania, alimentação e saúde. Em seguida ao referencial, será possível realizar os dois procedimentos metodológicos subsequentes, que são: a apreciação crítica do Projeto Educando com a Horta Escolar (PEHE) por meio da análise temática, e a elaboração das diretrizes em alimentação - também com a análise temática (MINAYO, 1992).

Este segundo procedimento metodológico objetiva que todo esforço teórico vise "ultrapassar o nível do senso comum e do subjetivismo na interpretação e alcançar uma vigilância crítica frente à comunicação de documentos, textos literários, biografias, entrevistas ou observação” (MINAYO, p. 203). A escolha da análise temática se deu porque se tem como objetivo da pesquisa o descobrimento dos "núcleos de sentido que compõem uma comunicação cuja presença ou frequência signifiquem alguma coisa para o objetivo analítico visado”, porque, na análise temática, o que importa, mais do que a expressão verbal, é a “compreensão simbólica de uma realidade a ser penetrada” (MINAYO, 1992, p. 220). 
A opção pela apreciação crítica do material do PEHE se deu pelo fato de que o foco do estudo é observar se os conceitos e as noções usadas no objeto são, de fato, condizentes com o que se propõe no que tange à temática da alimentação. Para tanto, será realizada uma divisão por temas dos conteúdos do material didático que sejam relevantes para os objetivos da pesquisa. A apreciação permitirá que se avalize se o objeto possui uma visão alternativa do alimento, ampliando a questão para a intersetorialidade, e se é pautado pelas noções de Segurança Alimentar e Nutricional.

A análise temática das diretrizes sobre alimentação percorre as seguintes fases:

\section{1) Diretrizes de alimentação}

1. Pré-análise: a escolha dos documentos a serem lidos e fichados em um documento à parte refere-se aos autores: CONSEA (2010), Costa (2011), Pollan (2007, 2008, 2010), Schlosser (2002), Ministério da Saúde (MS), Organização das Nações Unidas para Agricultura e Alimentação (FAO) e Organização Mundial da Saúde (OMS), Jacobsen e Nestlé (2000).

2. Exploração do material: foram estabelecidos alguns parâmetros para dimensionar a relevância dos assuntos: menções a marcos históricos e teóricos sobre Direito Humano à Alimentação Adequada (DHAA) e Segurança Alimentar e Nutricional (SAN); possibilidades de políticas públicas e ações da sociedade civil para promoção da alimentação saudável como direito humano; noções e dicas viáveis na abordagem da alimentação; inserção da alimentação além da temática da saúde e nutrição, demonstrando uma intersetorialidade e visão crítica; menções ao movimento de Promoção da Saúde.

3. Tratamento dos resultados obtidos e interpretação: foi utilizada a proposta já elucidada por Minayo (1992), que consiste em:

o Ordenação dos dados: todo o material sobre o assunto é compilado em um documento que une todas as considerações pesquisadas sobre alimentação.

o Classificação dos dados: ocorre baseada em “corpus” e da leitura transversal de cada corpo.

o Análise final: para esta fase, seguem as categorias centrais:

- Parte I: Alimentação: como fazer a nova abordagem? 16 Diretrizes;

- Parte II: Significado dos termos e classificações das informações sobre alimentos - 4 Diretrizes;

- $\quad$ Parte III: Comida e suas conexões com o meio ambiente - 4 Diretrizes; 
- $\quad$ Parte IV: Comida - uma questão cultural e política - 7 Diretrizes.

Quanto ao caminho metodológico do objeto, sua trajetória é delineada a seguir:

\section{1) Projeto Educando com a Horta Escolar}

1. Pré-análise: a pesquisa documental teve seu roteiro de investigação iniciado pela leitura completa do material didático do Projeto Educando com a Horta Escolar. O material estava disponível gratuitamente no sítio eletrônico ${ }^{3}$, o que possibilitou a leitura exploratória do mesmo. E, com a finalidade de obter mais informações, foram realizados contatos por $e$ mail e telefone à coordenadora do Projeto, Najla Veloso Barbosa (FNDE), bem como para Miriam Sampaio de Oliveira (FAO), que prestou auditoria ao PEHE.

Após solicitação, no primeiro semestre de 2011, a coordenadora Najla Veloso Barbosa enviou, via correio, todo o material didático impresso. O material consistia em cinco cadernos (três para docentes, dois para discentes), um caderno de mapeamento do projeto e dois DVDs explicativos.

2. Exploração do material: foi realizada uma leitura flutuante dos três cadernos para docentes, dos dois para discentes e também do caderno intitulado “Mapeamento do Processo”, que explica como se deu a implantação do PEHE. A leitura viabilizou a seleção do objeto de estudo, pois se notou, com base na leitura inicial, que o conteúdo revelava uma contraposição ao discurso da grande mídia.

Em seguida à leitura do Mapeamento, foi realizada a pesquisa documental da bibliografia do Projeto, visto que este é considerado o primeiro passo para a formação dos docentes participantes (PROJETO EDUCANDO COM A HORTA ESCOLAR, 2010). Com as referências disponíveis, foi realizada uma pesquisa exploratória em bibliotecas e bases de dados eletrônicos, e as obras foram encontradas principalmente nas bibliotecas da Faculdade de Saúde Pública da Universidade de São Paulo (FSP-USP), Escola de Comunicações e Artes (ECA-USP) e Universidade Federal de São Paulo (UNIFESP). Com base nessa investigação preliminar, foi elaborado um plano de leitura (ECO, 1996), dividido por núcleos temáticos: comunicação e cidadania; comunicação e saúde; comunicação e alimentação.

Em seguida a essa primeira pesquisa documental, ocorreram as entrevistas e reuniões com pesquisadores do assunto, como: Inesita Araújo (2004), umas das mais conhecidas pesquisadoras em comunicação e saúde; Maria Otilia Bocchini (1994), que tem, entre suas

\footnotetext{
${ }^{3}$ Site: www.educandocomahorta.org.br , que foi desativado no final de 2011.
} 
linhas de estudo, os temas da saúde e cidadania. Vale destacar também a importância das reuniões com a orientadora, $\operatorname{Prof}^{\mathrm{a}} \operatorname{Dr}^{\mathrm{a}}$. Alice Mitika Koshiyama, bem como com a Prof ${ }^{\mathrm{a}}$. $\operatorname{Dr}^{\mathrm{a}}$. Ana Maria Cervato-Mancuso, que coordena o grupo em SAN na Faculdade de Saúde Pública (FSP-USP). Além disso, para ter mais conhecimento em SAN, a pesquisadora passou a assinar boletins da Faculdade de Saúde Pública (FSP-USP) e da Associação Brasileira de Saúde Coletiva (ABRASCO).

3. Tratamento dos resultados obtidos e interpretação: em consonância com o aprofundamento bibliográfico, foram realizadas releituras do material didático, que geraram os seguintes processos:

o Ordenação dos dados: todo o material didático foi armazenado em um arquivo à parte, com fichamentos e anotações dos principais pontos a serem analisados.

o Classificação dos dados: em seguida às entrevistas e ao aprofundamento teórico, o material didático passou por diversas releituras, de forma que possibilitasse a ordenação do material.

o Análise final: a análise final será baseada na divisão dos temas em gavetas, com categorias centrais, que se unem para chegar a uma lógica interpretativa. 


\section{Cidadania e comunicação}

Cidadania é um conceito inacabado, em movimento, com interpretações distintas dos teóricos que estudam a temática, como Marshall (1963), Bobbio (1992), Hirschman (1992) e, no contexto nacional, o conceito passa a ser debatido depois de Dagnino (2004) e Carvalho (1996). O capítulo dará uma visão panorâmica de como se realizou o processo de cidadania no Brasil e, por fim, situará a importância da comunicação na construção da cidadania, baseada nos pensamentos de Gentilli (2005), Arendt (1973) e Lima (2012).

\subsection{Cidadania: principais conceitos}

Ao considerar a cidadania e a construção dos direitos do homem, Marshall (1963, p. 76), em sua clássica obra 'Cidadania, status e classe social', conceitua cidadania como um “[...] status concedido àqueles que são membros integrais de uma comunidade” e como um princípio de igualdade. O autor define status social como uma "[...] posição geral de um indivíduo com relação aos outros membros da sociedade ou de algum setor dela [...] ou seja, sua posição em função dos valores sociais vigentes na sociedade”. (MARSHALL, 1963, p. 152). O autor afirma que a consolidação da cidadania ocorreu juntamente com o capitalismo, uma vez que está vinculada à visão de classe burguesa, que se baseia no princípio da liberdade como direito fundamental.

Carvalho (1996) entende que cidadania é a forma como as pessoas se relacionam com o Estado, ao mesmo tempo em que reconhecem a identidade nacional como ingrediente indispensável à cidadania. O autor ressalta que a construção da cidadania possui um período de amadurecimento e aprendizado, que varia conforme o país, já que o cidadão político “[...] não nasceu adulto em lugar nenhum.” (CARVALHO, 1996, p. 344).

Afirma Abreu (2003, p. 16-18) “[...] ser cidadão é estar incluído na comunidade, e assinala que a atuação do cidadão pode ocorrer na esfera privada e pública, sendo possível exercer a cidadania nas instâncias em que a sociedade está” - escolas, trabalho, meios de comunicação, entre outros.

Já Bobbio (1992) coloca que a democracia é a sociedade dos cidadãos, e que os indivíduos se tornam cidadãos quando lhes são concedidos alguns direitos fundamentais. Para esse autor, a sociedade democrática não é um corpo orgânico, mas uma soma de indivíduos (BOBBIO, 1992). Outra concepção que merece destaque é a de que a democracia moderna é centrada no individualismo e, se tal concepção for eliminada, “[...] não será mais possível justificar a democracia como uma boa forma de governo” (BOBBIO, 1992, p. 120). Da 
mesma forma, em uma Constituição democrática, em primeiro lugar vem a liberdade dos cidadãos, em seguida o poder do governo, constituído por cidadãos que a formam e controlam através de suas liberdades.

Articulando cidadania e informação, dois traços definidores das sociedades contemporâneas é a “[...] universalização de direitos e a consagração da democracia como a forma mais avançada que o homem pode conceber para sua organização social”, acredita Gentilli (2005, p. 93). Como componente da democracia, a cidadania implica na inclusão, no direito de ser "[...] plenamente representado, de ter acesso aos mercados e participar da vida em comum e das decisões coletivas de forma plena.” (GENTILLI, 2005, p. 96). A cidadania teve como matriz teórica o conceito de emancipação liberal e a sociedade democrática representa uma instituição em constante movimento.

Numa democracia, todo homem, independente de suas condições de vida, formação ou posição social, tem o direito assegurado de participar das decisões coletivas que lhe dizem respeito (GENTILLI, 2005). No entanto, esse direito encontra-se no plano da possibilidade, já que, para se ter a plena cidadania, o indivíduo tem que lidar com conflitos inerentes a uma sociedade desigual. Nota-se que o termo cidadania retoma variados significados, e a concepção de cidadania dos teóricos perpassa pelo contexto histórico da formulação dos direitos de cidadania, isto é, os direitos civis, políticos e sociais, conforme será mostrado a seguir.

\subsubsection{Os direitos de cidadania}

Foi Marshall (1963) que elaborou a clássica divisão da cidadania em três componentes, na seguinte cronologia: direitos civis, políticos e sociais. Os direitos civis, que foram estabelecidos no século XVIII, constituíram-se como liberdade individual, de dona de seu próprio corpo, do direito de ir e vir, de propriedade, de escolher, por exemplo, seus pensamentos e sua fé. Por prezar as conquistas individuais, é o direito que mais se harmoniza com o capitalismo.

Os direitos políticos, que se desenvolveram na Revolução Francesa e tiveram sua consolidação no século XIX, estabelecem os mecanismos de participação no Estado e constituem-se no direito de participar do poder político, seja como organismo na esfera política, seja como eleitor (MARSHALL, 1963). Já os direitos sociais foram consolidados somente no século XX e se referem ao direito do mínimo de bem-estar econômico e social, a fim de levar uma vida civilizada de acordo com os padrões da sociedade em que o indivíduo 
se insere. Os direitos sociais permitem que o sujeito participe dos padrões básicos de vida, igualitariamente, com os outros indivíduos da sociedade.

Por ser o último dos direitos consolidados, Marshall (1963) e Gentilli (2005) denunciam uma deturpação das ideias que rondam os direitos sociais. O pensamento da cidadania ainda coloca a proteção dos direitos sociais como uma caridade, não como uma legislação liberal, perdendo o status de direito. Esse pensamento se dá porque os direitos sociais não são direitos de liberdade, são direitos de necessidade, sendo o papel do Estado indispensável na garantia de tais direitos.

Outra deturpação de conceitos se deu com o termo liberdade. Se, na democracia ateniense, a liberdade consistia na possibilidade de participar ativamente nas decisões políticas, nas democracias modernas, liberdade é relacionada diretamente ao pleno exercício dos direitos civis (GENTILLI, 2005). Isso porque, para os antigos, o conceito de liberdade era ligado à esfera pública. Hoje, no entanto, o conceito de liberdade está relacionado à esfera privada. Tal separação acarreta um pensamento de que liberdade seja um direito civil, ligado à esfera privada, e os direitos políticos estejam ligados à esfera pública, levando a uma desarticulação entre questões públicas e privadas.

Marshall (1963) acredita que a cidadania e o capitalismo evoluíram juntos, isto é, na metade do século XVII, mas em direções opostas. Isso porque a cidadania quer que o status de cidadão aumente e seja conferido ao maior número de pessoas. Já o capitalismo, por se basear na desigualdade, requer que o status de cidadão não seja conferido a todos.

As contribuições de Marshall (1963), para explicar os direitos do homem e entender o significado dos termos de acordo com o momento histórico, representam uma contribuição no entendimento de cidadania. E, baseado na experiência da Inglaterra, o teórico traça um panorama que possibilita enxergar os direitos de cidadania sob uma perspectiva de evolução cronológica. Esta visão, no entanto, gerou diversas críticas, como será apresentado nos tópicos seguintes.

\subsubsection{Críticas ao modelo marshalliano de cidadania}

Embora Marshall (1963) seja uma das principais referências sobre o assunto, sua visão foi criticada por outros estudiosos, como o fizeram, de maneira explícita, Hirschman (1992) e Saes (2000). Entre a série de críticas à leitura de Marshall (1963), a principal delas é o fato de este enxergar a cidadania como um processo evolutivo, isto é, como se a construção dos direitos do cidadão fosse uma grande escada a ser subida. Os críticos de Marshall (1963) 
consideram que os direitos, principalmente os sociais, só foram conquistados por meio da pressão política, e que um direito pode evoluir ou cair em desuso, conforme o tempo histórico, de acordo com os interesses da nação ou da classe que constitui maior poder político.

Em seu artigo, Saes (2000, p. 10) pontua que a visão marshalliana subestima "o potencial do processo revolucionário na destruição do status feudal” e que "tende, em substituição, a encarar o processo de instauração da cidadania civil como um processo de evolução institucional”, desconsiderando saltos qualitativos neste processo. Saes (2000) aponta que Marshall (1963) coloca a evolução da cidadania como natural e constante, isto é, que avança sem necessidade de grandes mudanças estruturais, por exemplo, de regime político.

Outro ponto que Saes (2000) critica no texto de Marshall (1963) é que este autor não especifica o papel das classes trabalhadoras no processo de formação e evolução da cidadania. Isso porque, para Saes (2000, p. 46), “uma cidadania plena e ilimitada, conforme com as exigências ideológicas subjacentes ao conceito apresentado por Marshall, situa-se além do horizonte da sociedade capitalista e das suas instituições políticas.”

Saes (2000) acredita que a concessão de direitos não muda a macroestrutura do capitalismo, isto é, que a passagem de um estágio a outro da cidadania é um processo que não destroi o sistema capitalista. O autor ainda reforça que, mesmo com essa impossibilidade, os direitos sociais não são desejados pela classe dominante, porque, por mais que não acabe com seu poder, os direitos sociais são fatores limitantes dos direitos individuais capitalistas.

Desta maneira, os únicos direitos indispensáveis à existência do capitalismo são os direitos civis, que dispensam também os direitos políticos, porque não se configuram como “único mecanismo viável de legitimação da ordem social capitalista” (SAES, 2000, p. 24). Já os direitos sociais tornaram-se um instrumento para que as classes trabalhadoras consigam reproduzir sua capacidade de trabalho "num nível compatível com o estágio alcançado pelo capitalismo.” Com isso, os direitos sociais seriam um instrumento adotado pela classe trabalhadora para tentar, ao conquistar novos direitos, obter aquilo que os direitos civis não conseguiram implementar: a "realização da igualdade entre os homens” (SAES, 2000, p. 27).

Saes (2000, p. 28) acredita que os direitos se encontram em constante mudança, visto que, nas sociedades capitalistas, os direitos sociais podem passar por períodos ou situações em que estejam declinantes ou mesmo ausentes. Nesse sentido, a única mudança que os trabalhadores efetivamente conseguem na sociedade capitalista é sua influência política, isto 
é, “a capacidade de alterar marginalmente as decisões tomadas pelos governantes”, mas sem chegar ao essencial, que é dirigir o processo de tomada das decisões governamentais.

Para manter a desigualdade inerente ao capitalismo, a classe capitalista utiliza o poder decisório da burocracia a seu favor, por meio de pressões do tipo pessoal, econômico e político sobre os agentes burocráticos. O aparato burocrático é um mecanismo adotado pelos capitalistas para que se obtenham decisões governamentais favoráveis a questões que legitimem a ordem social capitalista, bem como para bloquear a participação política da maioria social. Saes (2000, p. 33) reitera que até mesmo a instauração do sufrágio universal e do regime democrático "não implica o estabelecimento de um efetivo controle dos governantes pela maioria social." Como solução a essa controvérsia, o autor coloca a necessidade de uma ruptura no processo institucional, seja por um golpe de Estado, seja por revoltas populares. Isso porque a democracia representa nada mais, nada menos, do que um “instrumento de ‘ventilação’ do aparelho de Estado capitalista, promovendo uma rotação mais rápida” de uma “mesma fração capitalista pelo aparelho de Estado” (SAES, 2000, p. 34). A democracia seria um instrumento utilizado pela elite para mostrar uma suposta concretização da "soberania popular".

Em resumo, a baixa participação da sociedade na vida pública se dá pela burocratização do aparelho estatal e pela superioridade de recursos políticos das classes dominantes, que são fortes instrumentos de ações e pressões. Como consequência, há uma apatia política, por meio do abstencionismo eleitoral, e um desinteresse pela macropolítica e pela vida político-partidária. O autor salienta que, para a vida política, essa apatia é um estado ótimo para o bom funcionamento da democracia.

Ainda que existam as limitações do sistema capitalista, propõe-se que, se a sociedade quiser mudança, não pode adotar um comportamento passivo ou de inércia, típico da sociedade conservadora, depositando "suas esperanças na eficácia política do 'fator de inércia”” (SAES, 2000, p. 38). O fator inércia seria uma crítica explícita a Marshall (1963) e ao seu esquema evolutivo dos processos de cidadania.

Outra solução apontada por Saes (2000, p. 42) é a participação da população nas microesferas políticas, que são um treinamento e aprendizado para a participação nas macroesferas das instituições políticas. Assim, instituições da sociedade civil são instrumentos que viabilizam a participação na democracia participativa, embora ainda encontrem variadas dificuldades, sobretudo a carência de recursos públicos. Tais barreiras fazem com que a intervenção das massas na gestão dessa esfera microssocial seja "periférica, marginal e secundária”. O autor conclui que os direitos do homem não se dão e não se darão 
de forma evolutiva no contexto da sociedade capitalista e que, para acabar com as desigualdades, a única maneira efetiva é a interrupção da ordem política vigente.

Outra visão sobre a temática da construção da cidadania é colocada pela filósofa Heller (2008), que também discorda de Marshall (1963), mas adota uma posição menos radical que Saes (2000). Ao contrário deste, Heller (2008) acredita que a revolução se dá pelo cotidiano, e não por uma interrupção abrupta da construção política. Para ela, a cidadania é uma construção cotidiana, ou seja, não alicerçada em saltos evolutivos drásticos, mas em revoluções constantes e permanentes.

Para tanto, a história social pode ser relacionada com o cotidiano de todo ser humano, visto que o cotidiano “não está ‘fora’ da história, mas no ‘centro’ do acontecer histórico: é a verdadeira essência da substância social” (HELLER, 2008, p. 34). Todo acontecer histórico parte de subjetividades e da cotidianidade do indivíduo; e a história, como substância heterogênea da sociedade, cria seus valores não como objetividade natural, e sim como objetividade social, de acordo com o critérios socialmente construídos. A autora destaca o conceito de valor como tudo aquilo que produz diretamente a explicitação da essência humana ou é condição de tal explicitação (HELLER, 2008).

O critério de desenvolvimento de determinado valor não se dá de forma natural: os próprios homens, em determinado tempo histórico, determinam se tal valor deve ser hierarquicamente priorizado ou não. Contudo, como seres sociais, os seres humanos convivem em esferas heterogêneas, tais como: de produção, relações de propriedade, estrutura política, vida cotidiana, moral, ciência, arte, entre outras (Estas esferas não possuem hierarquia universal de valor, e sim existem "a partir do ponto de vista de tarefas e decisões dadas em relação a fins concretos” (HELLER, 2008, p. 13). Ou seja, a hierarquia existe baseada no momento em que os humanos dizem que tal esfera possui maior valor do que outra naquele tempo histórico.

Ainda, de acordo com a mesma autora, não há nenhuma esfera hierarquicamente superior a outra - somos nós, os humanos, que hierarquizamos as esferas de acordo com o valor que os próprios indivíduos, situados em determinado tempo-espaço, dão a tais esferas. $\mathrm{O}$ critério de valor não é contínuo na história da humanidade: há momentos em que determinada esfera, como a arte, a liberdade social, etc. podem se desenvolver em determinado estágio ou perder totalmente o valor ou a importância. Partindo dessa lógica, entende-se que determinado valor ou moral é modificado pela humanidade, de acordo com o momento histórico em que vive. Por exemplo, o valor de ser individualista ou ambicioso, em dado momento histórico, é 
um valor negativo. Hoje, no entanto, ele é valorizado pelo senso comum. Há fases históricas em que determinados valores ficam estéreis ou podem entrar em colapso.

Pensando neste ciclo, “[...] nem um só valor conquistado pela humanidade se perde de modo absoluto; tem havido, continua a haver e haverá sempre ressurreição” (HELLER, 2008, p. 22). Para essa autora, por ser histórico, o valor permanece - ainda que caia, por determinado período de tempo, em desuso ou no esquecimento. No entanto, por fazer parte do ciclo histórico, os valores são constantemente reformulados - é a “[...] invencibilidade da substância humana, a qual só pode sucumbir com a própria humanidade, com a história” (HELLER, 2008), ou seja, enquanto houver humanidade e história, haverá o desenvolvimento axiológico descrito. Para que determinado valor seja recuperado em meio a tantas esferas heterogêneas, é preciso conhecimento e tomada de posição:

Quanto maior for o número de juízos de fato (de fato na realidade e na possibilidade) iluminados por uma teoria, quanto mais claramente ela revelar qual é o caminho da explicitação do valor e quais os obstáculos que se opõem a seu desenvolvimento, tanto mais verdadeira e objetiva será tal teoria (HELLER, 2008, p. 26).

Quanto mais se souber da teoria, melhor se conhecerá qual caminho trilhar e como agir diante do fato de se saber que é sujeito da história e passível de mudá-la.

A autora também reconhece que a heterogeneidade da realidade dificulta sobremaneira as escolhas e as formas de saber qual é a melhor decisão diante das possibilidades de escolha - esta, muitas vezes, não tomada individualmente, diante das influências do homem como ser social (HELLER, 2008). Ainda assim, com a teoria e conhecimento histórico, o ser humano compreende as alternativas disponíveis como uma construção humana, dando a permanente possibilidade de mudar a história: “[...] não era obrigatório que o desenvolvimento social tomasse a forma que tomou; simplesmente foi possível que surgisse essa configuração” (HELLER, 2008, p. 28). Ou seja, o olhar fatalístico e naturalizado das estruturas de nossa sociedade não é verdadeiro - as coisas aconteceram porque foi possível que acontecessem, não que fossem inevitáveis.

Heller (2008) salienta que, mesmo que se tenha conhecimento teórico a respeito de um fato histórico, o ser humano só age como sujeito na história e se sobrepõe de sua vida cotidiana - isto é, a vida de todos os homens, com base na elevação do sujeito individual para o ser humano genérico. Por humano genérico, entende-se o homem que vive como sujeito moral, isto é, inserido na história. Já o ser individual é aquele que se volta às suas necessidades individuais, imediatas, a fim de sobreviver no cotidiano. 
Todo homem tem essas duas facetas: o ser humano individual e o ser humano genérico, e as duas dimensões são vivenciadas em sua cotidianidade. Quando vive sua individualidade, seu cotidiano, o ser humano busca suas necessidades individuais. Mas essa visão do ser individual, de vivência cotidiana, é a que mais se dá para a alienação, porque o ser humano não consegue compreender as dimensões maiores em que se insere, ou seja, sua atuação como ser humano genérico. Nesta dissertação, toma-se a noção de alienação como sendo

[...] alienação em face de alguma coisa e, mais precisamente, em face das possibilidades concretas de desenvolvimento genérico da humanidade. [E esta existe], [...] quando ocorre um abismo entre o desenvolvimento humano-genérico e as possibilidades de desenvolvimento dos indivíduos humanos, entre a produção humano-genérica e a participação consciente do indivíduo nessa produção. (HELLER, 2008, p. 57-58).

Isso se dá, sobretudo porque, com toda a heterogeneidade de atividades cotidianas, o ser humano não percebe a conexão entre as coisas e não estabelece relações, ainda mais sob o pano de fundo do conformismo para se ter uma vida boa e levando em conta sua fé.

A autora considera que todos têm uma dose de conformismo, que se apresenta como ultrageneralizações e estereótipos. Mas, o conformismo significa um problema quando invade territórios que não são da cotidianidade, principalmente nas decisões morais e políticas. Para quebrar esse ciclo, é necessária uma dose de conflito, que representa “[...] a rebelião das sadias aspirações humanas contra o conformismo” (HELLER, 2008, p. 126).

Vale ressaltar que o cotidiano não é considerado negativo para a autora. Contudo, o homem, para sair da lógica da alienação, precisa realizar o processo de homogeneização, isto é, sair do ser humano individual, que pensa somente em suas necessidades, para o ser humano genérico, que se propõe a atuar com valores universais, para a humanidade como um todo. Uma maneira de possibilitar o desenvolvimento do ser humano genérico é baseada na moral, a relação entre atividades humanas (cujo propósito é estabelecer uma relação entre os humanos para que estes convertam suas necessidades imediatas (e egocêntricas) a algo mais elevado. Nesse sentido, os valores morais são meios para que os indivíduos elevem-se conforme sua particularidade e tenham a nossa consciência - uma relação consciente com a comunidade em que convive, que também configura, no homem, a sua própria “[...] consciência do Eu” (HELLER, 2008, p. 37).

Contudo, como as necessidades do 'eu particular' são as que aparecem primeiro e a sociedade contemporânea é calcada no capitalismo, são os direitos civis os mais facilmente concebidos e assimilados pela sociedade. Isso ocorre porque os direitos civis representam 
uma manifestação do ser particular, que quer suas necessidades atendidas, a fim de garantir sua liberdade. No entanto, para que os direitos sociais sejam exercidos, é necessário sublimar parte desse ser particular para atender às necessidades do ser humano genérico, isto é, que está sempre “[...] ‘contido’ em todo homem, em toda atividade do ser genérico, embora seus motivos sejam particulares” (HELLER, 2008, p. 36).

Assim, para garantir os direitos sociais, a não ser que o ser humano se eleve de sua cotidianidade para assumir-se como ser humano genérico, o homem não sairá de suas necessidades individuais e imediatas. Para tanto, precisa pensar, de maneira contextualizada, que é um ser social. E, ainda que seja necessário atender às suas necessidades, deve refletir para não cercear as do outro.

A autora finaliza seu pensamento apontando a necessidade de ética nas ações da vida humana. Como consequência do amadurecimento dessa ética, as ações do homem são realizadas não de maneira drástica, mas como uma revolução permanente, no cotidiano. Ela também afirma a importância de se considerar a trajetória da cidadania à luz dos fatos históricos, uma vez que os direitos de cidadania não são lineares. Esse pensamento é compartilhado por Hirschman (1992), estudioso que também critica o pensamento evolucionista de cidadania, cujos pensamentos serão abordados no tópico seguinte.

\subsubsection{Retóricas contrárias aos direitos humanos}

Assim como Heller (2008), Hirschman (1992) acredita que a mudança se dá por revoluções cotidianas e constantes, e não em sequência linear. O autor, em seu provocador livro 'A retórica da intransigência', expõe os argumentos retóricos usados tanto pela esquerda como pela direita para evitar ou desmotivar a mudança, isto é, como se dão as manobras políticas adotadas para “[...] derrubar as políticas e os movimentos de ideias 'progressistas”" (HIRSCHMAN, 1992, p. 15, grifo do autor). Em sua opinião, para que haja uma evolução na sociedade, é necessário entender o outro ser, isto é, os outros grupos de cidadãos. Mas, nas democracias mais avançadas, é justamente essa falta de comunicação entre os grupos de cidadãos que geram os conflitos entre conservadores e liberais, progressistas e reacionários.

Hirschman (1992, p. 77) considera seu estudo uma “[...] correção ao otimismo de Marshall”, e cria três teses que derrubam as investidas progressistas delineadas por Marshall (1963): a tese da perversidade, da futilidade e da ameaça. Cada tese possui particularidades e 
se complementam no discurso retórico para desmobilizar as mudanças, conforme é exemplificado nos parágrafos seguintes.

Na tese da perversidade, qualquer ação que tenha como objetivo melhorar algo na ordem econômica, política ou social, pode até ser boa, mas as consequências podem trazer o objetivo oposto do inicial. Assim, qualquer movimento em direção à transformação mudará, sim, “[...] mas na direção contrária.. [ ] Com isso, [...] todos os tiros saem pela culatra" (HIRSCHMAN, 1992, p. 19).

Os filósofos do século XIX muniram-se de diversos apelos para atingir o efeito perverso, alcunhados por Hirschman (1992) como 'terrorismo intelectual', já que coloca os detentores do saber em posição superior ao cidadão, como se estes não conseguissem compreender as dinâmicas da sociedade.

Três exemplos históricos do uso da tese da perversidade podem ser mencionados: a condenação ao sufrágio universal, ao Welfare State, bem como o frequente sentimento de “fracassomania” que permeia a história da América Latina. Na Europa do século XVIII, enquanto alguns setores da sociedade exigiam a democracia política a todos os cidadãos, outros acreditavam na existência de um status de privilégio para somente poucos indivíduos isolados. Assim, a multidão nada mais é do que um grupo irracional e facilmente manipulável, que não conseguiria pensar os prós e contras da sociedade. Já na ocasião do advento do Welfare State, o filósofo Mandeville afirmou que o homem tinha uma inclinação para o ócio e que qualquer assistência estatal seria “[...] mais um incentivo à preguiça e à depravação, produzindo mais pobreza do que um alívio à mesma” (HIRSCHMAN, 1992, p. 31). Ou seja, a intervenção estatal levaria a um desequilíbrio da sociedade, e não à melhora do bem- estar da população. Por fim, no contexto da história da América Latina, a tese da perversidade se aplica no sentimento de "fracassomania”, como se as políticas e a historiografia da região apontassem para um sentimento de fracasso, e não de aperfeiçoamento da humanidade.

Para derrubar a tese da perversidade, pode-se comprovar historicamente que toda situação ou política tem efeitos secundários ou colaterais, podendo desviar-se do efeito pretendido de alguma ação proposital. É por isso que se deve atentar ao foco dado pelos reacionários em sua argumentação: frequentemente focam somente em um ponto - o que teve efeito político negativo -, ignorando os efeitos positivos da ação.

A segunda tese, a da futilidade, argumenta que as tentativas de transformação são inúteis, pois não mudam a essência, que é o fato de as estruturas profundas da sociedade 
manterem-se intactas. É considerada uma das “[...] armas mais importantes do arsenal reacionário” (HIRSCHMAN, 1992, p. 68), porque conclui que realizar alguma coisa é inútil.

Muitos dos teóricos que defendiam a tese da futilidade vieram da Itália e da Inglaterra do século XIX, e Tocqueville era seu precursor. No período, os considerados analistas de multidões da época ridicularizaram a luta pelo sufrágio universal, considerando que as mudanças seriam muito pequenas.

No que tange à aparição do Welfare State, a crítica principal era de que, ao receber renda, os pobres ficariam preguiçosos - sem contar as argumentações de que as rendas não chegariam ao destinatário, por causa da corrupção. Os defensores da tese da futilidade ainda subestimam as lutas pelos direitos sociais e por movimentos “[...] aparentemente imensos e marcantes” (HIRSCHMAN, 1992, p. 64), como a Revolução Francesa, a marcha pelo sufrágio universal e pela instituição da democracia, em fins do século XIX, bem como a subsequente consolidação do Welfare State.

Em comparação com as duas teses, Hirschman (1992, p. 65-67) considera que o efeito perverso tem afinidade com o mito e a religião, por ver um mundo consideravelmente volátil, onde qualquer ação pode trazer uma variedade de contramovimentos insuspeitados. E a tese da futilidade tem afinidade com a autoridade de nossa ciência, porque enxerga a evolução do mundo sob certas regras imanentes, o que inviabiliza a ação humana em modificar a ordem das coisas. O autor avalia que o argumento da futilidade é mais forte, por ser "[...] aparentemente menos extremo, mas no final acaba sendo muito mais exasperante” (HIRSCHMAN, 1992, p. 67).

De forma polêmica, esse mesmo autor critica tanto a retórica conservadora quanto a da extrema esquerda. Para ele, enquanto os conservadores pensam que a mudança não leva a nada, pelo fato de a estrutura possuir leis rígidas demais, os radicais pensam que as mudanças sociais não se darão se não houver uma revolução. Para contrapor esses discursos, o autor enfatiza que a tensão entre os planos de um programa social e sua efetividade é algo bem mais complexo que aquilo que é transmitido pelo contraste entre máscara e realidade. Ele finaliza sua provocação aos conservadores e radicais, ao incitar que "[...] sua mania de encontrar defeitos poderia perder sua capacidade de suscitar ação”. (HIRSCHMAN, 1992, p. 67)

A terceira e última retórica, isto é, a tese da ameaça, coloca que as consequências da mudança podem ser altas demais, podendo até piorar a situação. Esse argumento é “[...] mais complexo e historicamente mais fundado que os outros dois [ ] e parte do princípio de que ‘isso matará aquilo’”. (HIRSCHMAN, 1992, p. 76). 
Colocada no contexto do advento do Welfare State, a tese da ameaça foi usada pelos reacionários que consideraram a proposta ameaçadora tanto para a liberdade quando para a democracia, argumentos fortes e contrários a quaisquer mudanças no status quo.

Tal relutância, no entanto, pode ser refutada pela observação dos fatos históricos, visto que nem toda mudança de status quo é totalmente errônea ou correta. Na história denominada prática, a verdade é que o importante é encontrar combinações factíveis e possibilidades intermediárias entre a manutenção do status quo e a mudança, “[...] sem trabalhar sob a ilusão do apoio mútuo e sem perder a perspectiva dos perigos da ameaça” (HIRSCHMAN, 1992, p. 107).

Hirschman (1992) conclui que a tese da ameaça é menos eficaz que a da futilidade e a da perversidade porque, para que tenha efeito sobre uma sociedade, esta tem que possuir uma memória viva de reformas ou realizações altamente bem cotadas e que possibilitem ser postas em perigo pela nova 'medida'. Algumas sociedades são mais conscientes de seu processo histórico, bem como dos processos políticos responsáveis pelos estágios de progresso. Um exemplo é a Europa Ocidental, em que os pré-requisitos na construção de uma nação, isto é, efetivar a identidade cultural, garantir a autoridade sobre o território e possibilitar a participação das massas, foram tarefas construídas uma após a outra, com intervalos de séculos entre os processos. Já nas novas nações, como os países da América Latina, tais procedimentos foram enfrentados de uma vez só, reduzindo a efetividade da tese da ameaça.

Esse autor acredita na mutabilidade da validade de valores, já que os mesmos valores que ervem bem a uma sociedade em uma fase podem ser obstáculos em um momento histórico seguinte. Atualmente, tem-se a crença segundo Hirschman (1992, p. 110) no valor supremo da individualidade e na responsabilização individual dos atos e fatos, mas tais valores podem alterar quando um ethos comunitário ou solidário caso seja imprescindível.

Há uma sequência temporal "lógica” para as três teses: a da ameaça é usada assim que uma nova política é proposta ou oficialmente adotada; a tese da perversidade é usada assim que determinada política adquire alguns resultados insatisfatórios; já a argumentação da futilidade surge mais tarde, por demandar certa distância temporal, de maneira que seja possível uma avaliação de que um grande movimento social “[...] não passou de muito barulho a troco de nada” (HIRSCHMAN, 1992, p. 114).

A última parte do livro é repleta de provocações tanto à direita como à esquerda. De acordo com Hirschman (1992), os progressistas pensam que as coisas boas vêm todas de uma vez, enquanto que os conservadores acreditam que qualquer mudança acarretará a danos às reformas antigas. Assim, enquanto que os conservadores têm medo da mudança, articulando- 
se de diversas formas para impedi-la, os progressistas, ao contrário, têm medo dos perigos da inação.

Uma posição considerada madura, em contraste com a retórica reacionária e radical, é o de que existem perigos e riscos na ação ou inação, e os riscos de ambas deverão ser descobertos e se possível evitados sempre que necessário. Além disso, em se tratando de prever desastres eminentes, “[...] é bom lembrar o ditado - o pior nem sempre é certo (de acontecer)” (HIRSCHMAN, 1992, p. 128).

Outra provocação lançada é a de que as teses reacionárias da futilidade acreditam na existência de uma lei geral que governa a sociedade. Por outro lado, os progressistas pensam que há um movimento para frente, um progresso também com caráter de lei. Tais visões extremadas de mundo são consideradas confortáveis, já que as pessoas sentem uma dose de confiança, “[...] por mais vaga que seja, de que a história está do seu lado” (HIRSCHMAN, 1992, p. 132).

O pensamento progressista de que é necessário reconstruir a sociedade do zero ou do nada, segundo ‘ditames da razão’, consiste em um limitador para o progresso real da história. Ademais, os conservadores possuem uma retórica claramente vantajosa à dos progressistas, pelo uso da ironia, elemento que deveria ser utilizado para quem quer a mudança. Mesmo assim, Hirschman (1992) pensa que, em linhas gerais, os argumentos usados pelos conservadores são, com frequência, falhos.

Em suas conclusões, o autor considera que sua contribuição é argumentar que ambas as posições são extremas e intransigentes, e espera permitir debates mais amistosos para com a democracia. Ele reconhece o poder da luta política, já que a história demonstra que os consensos são atingidos após longos períodos de debates, e para Hirschman (1992) somente com a 'tolerância e a aceitação' viabiliza-se tal consenso, resultando em um empate entre grupos opostos 'visceralmente hostis'.

As discordâncias ao modelo de Marshall (1963) e à visão mais extrema de Saes (2000) também integram o pensamento de Bobbio (1992), cujo tema central de seu pensamento é a efetivação dos direitos humanos, como será mostrado em seguida.

\subsubsection{Marcos históricos dos direitos do homem}

A temática do estabelecimento dos direitos do homem também foi abordada por Bobbio (1992), em seu livro, onde o autor considera que o conceito de democracia é tido como inseparável do conceito de direitos do homem, situando os direitos humanos como tema 
central de seus pensamentos. Bobbio (1992) considera que os direitos naturais são, na realidade, direitos históricos e nascem no início da era moderna, em consonância com a concepção individualista da sociedade. Contudo, ainda que o individualismo integre a base filosófica da democracia, o ser humano deve entender que, em face do Estado, não tem somente direitos privados, mas direitos públicos. Esse pensamento, segundo o autor, viabiliza não só a consolidação do Estado de Direito, como também a posterior transformação de um Estado de Direito para um Estado dos Cidadãos.

Por direito, o autor entende como uma referência a um sistema normativo, que pode ser "moral ou natural, jurídico ou positivo" (BOBBIO, 1992, p. 8). Desta forma, não existe direito sem obrigação ou uma norma de conduta. Há uma responsabilidade intrínseca à ideia de direito moral, uma vez que se introduz, necessariamente, a correspondente "obrigação moral” (BOBBIO, 1992, p. 9).

Os direitos só foram acrescidos por meio de lutas “em defesa de novas liberdades contra velhos poderes, e nascidos de modo gradual, não todos de uma vez e nem de uma vez por todas” (BOBBIO, 1992, p. 5). O autor destaca a consolidação dos direitos sociais, que, por serem os últimos a se firmarem, são considerados os direitos da segunda geração. E, na sociedade atual, ocorre a emergência dos direitos de terceira geração, que constituem uma categoria heterogênea de direitos, e o mais consistente destes são os direitos ecológicos, além dos direitos da mulher e dos animais.

Bobbio (1992, p. 6-7) acredita que os direitos não nascem de uma vez: "nascem quando devem ou podem nascer”, porque as exigências de direitos "nascem somente quando nascem determinados carecimentos”. Pensando de maneira prática, o autor não crê em direitos invioláveis ou naturais, visto que não passam de argumentações usadas como instrumentos persuasivos.

Outro pressuposto que norteia seu pensamento é o de que direitos humanos "são coisas desejáveis” e fins que merecem ser perseguidos. Um dos símbolos do reconhecimento de uma cidadania para o mundo foi a Declaração Universal dos Direitos do Homem, aprovada na Assembleia-Geral das Nações Unidas, em 10 de dezembro de 1948.

Contudo, mesmo que os direitos sejam desejáveis, não foram ainda todos eles reconhecidos. Isso se dá muito pela ilusão do fundamento absoluto, isto é, de que tudo terminará por encontrar um argumento irrefutável na resolução dos direitos, em que todos concordarão e passarão a aderir. Só que, para Bobbio (1992, p. 18), isso não existe: o fundamento é irresistível no plano das ideias, mas não existe na realidade das pessoas racionais. Por conta disso, para que se caminhe a um consenso, são necessárias concessões de 
ambas as partes, em direção a valores últimos, com renúncias recíprocas, em que entram em jogo “[...] as preferências pessoais, as opções políticas, as orientações ideológicas”. (BOBBIO, 1992).

O autor também é enfático quanto aos valores que norteiam a criação dos direitos. Ele pensa que os direitos do homem vão e voltam, e a história demonstra que 'constituem uma classe variável', isto é, os direitos se modificam e continuam a se modificar conforme as condições históricas (BOBBIO, 1992, p. 18, grifo do autor).

Além de considerar que não existem “direitos fundamentais por natureza”, até mesmo os direitos que existem em estatutos entram em contradição entre si. Tal concorrência de direitos torna-se oportunidade aos detentores do poder para que se imponha uma preferência de prioridade conforme a situação.

Um dos aspectos enfatizados pelo autor é a diferença da aplicabilidade dos direitos civis e dos sociais. Os direitos civis representam direitos negativos, isto é, “[...] obrigações puramente negativas, que implicam a abstenção de determinados comportamentos.” (BOBBIO, 1992, p. 21). Já os direitos sociais possuem um caráter de obrigações positivas, pois implicam a imposição de condições a outros. Em resumo, direitos civis consistem em liberdades, enquanto que os direitos sociais incidem sobre poderes.

Bobbio (1992) relembra que um dos discursos mais usados na defesa dos direitos individuais é o de que, quanto mais liberdade tem o indivíduo, maior será seu progresso moral e material da sociedade. No entanto, tal crença é colocada como historicamente falsa, pois é mais um argumento usado pelos conservadores quando querem defender suas posições.

No que concerne à Declaração Universal dos Direitos do Homem, o autor acha que, se grande parte dos governos concordou com tais declarações, “[...] é sinal de que encontraram boas razões para fazê-lo.” (BOBBIO, 1992, p. 23). Entretanto, um dos principais argumentos adotados pelos conservadores na efetivação dos Direitos não é a falta de fundamento, mas a impossibilidade de realizá-los. Seria, na argumentação dada por Hirschman (1992), o uso da tese da futilidade, de que a mudança é inútil. Bobbio (1992) acredita que, hoje, o problema em relação aos direitos do homem não é sua justificativa, mas sua proteção e execução. Assim, a Declaração é um dos grandes feitos da humanidade, pois em resumo tratase “[...] de um problema não filosófico, mas político [...] somente depois dela é que se pode ter a certeza de que a humanidade partilha de alguns valores comuns”. (BOBBIO, 1992, p. 30-31, grifo nosso). Mesmo com tais valores comuns, sua aplicabilidade e proteção dependem do Estado que os reconhece, o que leva à conclusão de que os direitos do homem são direitos somente do cidadão deste ou daquele Estado ou nação em particular. 
O fato de os direitos serem considerados como fruto das lutas históricas do ser humano, leva-os ao caráter de mutáveis e passíveis de uma transformação e de ampliação. Nesse sentido, até mesmo a Declaração não pode ter a pretensão de ser definitiva, já que a história se transforma juntamente com as demandas dos seres humanos.

Para retroceder a execução dos direitos, são adotados dois tipos de ação e de controle social: a influência e o poder, que acarretam em dois grandes problemas mundiais - a guerra e a miséria. A guerra simboliza um poder excessivo “[...] que cria condições para uma guerra exterminadora [...] e a miséria é fruto do excesso de impotência que condena grandes massas humanas à fome” (BOBBIO, 1992, p. 45-6). Outro dilema que a humanidade ainda tem dificuldade de conceber é o de que tanto o progresso científico como o técnico são, de fato, efetivos, contínuos e irreversíveis; por outro lado, o progresso moral é difícil de mensurar, e varia em cada nação - e a percepção dessa dinâmica consiste em outra justificativa que inviabiliza a teoria marshalliana de cidadania.

Este autor pensa que, para a efetivação dos direitos, em uma sociedade baseada nas liberdades individuais, é necessário estabelecer a moral baseada não só do ponto de vista da sociedade, mas do indivíduo. E, tal qual Heller (2008), para o autor, uma revolução radical pode ocorrer gradativamente, porém “[...] não necessariamente de modo revolucionário”. (BOBBIO, 1992, p. 57).

O autor conclui que a emergência de novos direitos é sintoma de que "[...] o mundo das relações sociais de onde essas exigências derivam é muito mais complexo”, (BOBBIO, 1992, p. 75) e que os homens não nascem nem livres nem iguais (BOBBIO, 1992). Além disso, tais demandas demonstram que a existência dos chamados direitos fundamentais, como os direitos à vida, à liberdade e à propriedade, não foram o suficiente para a concretização da democracia e dos direitos do homem.

Nota-se que o esquema evolucionista de Marshall (1963) é criticado, explicitamente, por Hirschman (1992) e Saes (2000), e, de maneira indireta, por Heller (2008) e Bobbio (1992). Vale destacar outra crítica a Marshall (1963), que é o fato de enfatizar a construção da cidadania no contexto da Inglaterra, o que é menos aplicável a países em que o progresso fora pouco regular, sequencial ou ordenado (HIRSCHMAN, 1992), como é o caso do Brasil, tema do próximo tópico. 


\subsection{A construção da cidadania no Brasil}

A cultura política no Brasil foi criada com base em uma cidadania regulada, com a naturalização das relações sociais de dominação entre cidadãos e Estado (FERNANDEZ; MENDES, 2007). Compartilhando essa visão, Carvalho (1996), em seu artigo traça a trajetória da cidadania no Brasil inserida no contexto mundial, e, baseando-se na concepção do autor Bryan S. Turner (1990 citado por CARVALHO, 1996, p. 338), elenca a existência de dois eixos que compõem a construção da cidadania.

O primeiro eixo é:

- De baixo para cima: os cidadãos lutaram por seus direitos civis e políticos, ao final conquistando o Estado;

- De cima para baixo: o movimento foi oposto, isto é, o Estado foi criando os direitos e os cidadãos foram incorporando ou não tais direitos.

O segundo eixo refere-se à dicotomia público-privado, em que:

- Público: a sociedade conquista a cidadania dentro do espaço público, com a conquista do Estado;

- Privado: organizações voluntárias querem barrar a intervenção do Estado na vida privada, ou seja, os direitos são uma garantia dos direitos individuais.

Outro eixo corresponde à cultura política na construção da cidadania, elaborado por Gabriel Almond e Sidney Verba (1965 ${ }^{4}$ citado por CARVALHO, 1996, p. 338), e possui três tipos de cultura política: a paroquial (ou localista), a súdita e a participativa. Existe também um quarto tipo de cultura política, a cívica, que corresponde à combinação dos três tipos anteriores.

Define-se cultura paroquial como aquela totalmente alienada do sistema político, reduzindo as pessoas ao seu círculo familiar privado. Já a cultura súdita é aquela em que se concebe a existência de um sistema político, mas as pessoas se relacionam com esse sistema somente baseadas no que elas visualizam como obras de decisões político-administrativas. Por último, a cultura participativa acrescenta também a percepção de que é possível se integrar com o sistema e os processos que envolvem as decisões políticas. Há várias combinações dos três tipos, uma vez que cada setor da sociedade se relaciona com o sistema político de maneira diferente.

Carvalho (1996) utiliza os modelos de cidadania alicerçados na experiência da Inglaterra, da França, dos Estados Unidos e da Alemanha; e o modelo de cidadania

\footnotetext{
${ }^{4}$ Menção ao clássico estudo: ALMOND, G. A.; VERBA, S. The civic culture: political attitudes and democracy in five nations, an analytic study. Boston: Little, Brown \& Company, jun. 1965. 379 p.
} 
implementado no Brasil assemelha-se - apesar das diversas particularidades - ao da Alemanha. Isso porque ambas foram construídas de cima pra baixo e dentro do espaço privado.

Neste tipo de cidadania, a centralidade do Estado não garante o caráter público, tampouco universalista. No caso do Brasil, há uma troca de interesses entre Estado e cidadão, ou seja, o Estado seleciona os cidadãos que lhes interessam e os cidadãos recorrem ao Estado para assegurar seus interesses privados - conceito definido por Carvalho (1996) por Estadania.

Entretanto, na construção da cidadania, existem diferenças entre Brasil e Alemanha. Neste país, muito pela tradição luterana, há uma visão de obediência ao poder e às leis, além de uma identidade nacional por conta da etnia germânica. No Brasil, tais concepções inexistem, porque, embora se tenha um Estado centralizador, não há uma identidade nacional, muito menos uma atitude legalista diante do Estado. Ao contrário, ainda que os brasileiros saibam da existência do Estado, sua relação com ele é frequentemente desrespeitosa e anarquizante, conforme expõe Carvalho (1996).

Esse mesmo autor considera que, para ser um cidadão ativo, a nação articula uma conquista de cidadania de baixo para cima. No entanto, no Brasil, predominava no século XIX uma cidadania caracterizada por um "privatismo”, construída de cima para baixo, e com uma cultura política que se articulava entre paroquialismo e caráter súdito, isto é, uma cidadania inativa, com alguns sinais de ativismo político.

Em 1850, os "principais pontos de contato entre cidadão e o Estado se davam pelo voto, a Guarda Nacional, o serviço militar, o serviço do júri, o recenseamento e o registro civil” (CARVALHO, 1996, p. 342). Assim, um dos exercícios dos direitos políticos ocorria quando se era jurado, representando a democratização da Justiça; outro exemplo era o cumprimento dos deveres cívicos, quando militares integravam a Guarda Nacional, representando a democratização do Exército; já as eleições representavam a democratização do Poder Executivo.

Nota-se que direitos restritos a parcelas da população foram as bases da concepção da cidadania no país, considerando que o voto, os juízes de paz e a democratização do exército, à época, eram apontados como "baluartes” da expressão da cidadania.

Um dos marcos na saída da cultura de política paroquial para a cultura de tipo súdito foi a experiência da guerra da Tríplice Aliança contra o Paraguai, de 1865 a 1870, que fez com que o Estado solicitasse a indivíduos, até então considerados não cidadãos, que fossem 
lutar por sua pátria: mulheres, ex-escravos e soldados tiveram, pela primeira vez, uma participação cidadã.

No entanto, o avanço do Estado oitocentista, com o objetivo de regular a sociedade, também gerou revoltas. O Registro Civil, lei regulamentada em 1851, e a implantação do Sistema Métrico, adotado por lei em 1862, constituem-se em ações do Estado que não foram bem recebidas por parte da população. As reações negativas não se deram pela recusa da cidadania, mas simbolizavam a recusa de "[...] uma regulação vinda de cima, sem respeito e sem consulta por costumes e valores tradicionais” (CARVALHO, 1996, p. 354).

Apesar das revoltas da população, tais iniciativas foram adotadas por todos os Estados, na medida em que tiravam esses serviços públicos da tutela da Igreja e dos grandes proprietários. O lado positivo dessa adoção massiva foi que as iniciativas do governo permitiram que as pessoas tomassem consciência da presença do Estado, saindo um pouco do âmbito privado em que viviam.

Enquanto isso, na visão do mesmo autor, grande parte dos cidadãos brasileiros esclarecidos do século XIX consideravam a cidadania sob os parâmetros dos modelos europeus, porém com a compreensão de que devia se adaptar "a uma realidade muito mais intratável”, ou seja, uma cidadania que lida com a teoria e o operacional.

De acordo com Carvalho (1996), entende-se que, no Brasil, a construção da cidadania se deu de cima pra baixo e de maneira privada. Tal concepção de que os direitos de cidadania servem para garantir os direitos individuais acaba restringindo a cidadania como caridade ou imposição estatal, não como direitos conquistados com a luta da sociedade civil.

Outra abordagem da construção da cidadania em território nacional é dada por Dagnino (2004), em seu artigo - 'Sociedade civil, participação social e cidadania: de que estamos falando?'. A autora aponta que o conceito de cidadania foi retomado somente com a redemocratização, ao final dos anos de 1970 e ao longo dos anos de 1980, quando o Brasil viveu um processo de constituição da cidadania conectada com os direitos humanos. Isto como parte de uma concepção que “[...] buscava implementar um projeto de construção democrática, de transformação social, que impõe um laço construtivo entre cultura e política” (DAGNINO, 2004, p. 103). Esse vínculo indissolúvel se dá porque os projetos políticos não se restringem à atuação política, mas acabam por expressar e veicular significados que unem a matrizes culturais muito mais amplas.

A autora reforça que há um deslocamento de sentidos nos termos usados para definir os processos de cidadania em nosso país, e o conceito mais deturpado é a noção de cidadania, que “[...] penetrou profundamente no cenário político e cultural da sociedade brasileira” 
(DAGNINO, 2004, p. 103). O pensamento liberal reduziu as noções de cidadania de um significado coletivo, criado por movimentos sociais, para um “[...] entendimento estritamente individualista dessa noção” (DAGNINO, 2004, p. 106), esvaziando a responsabilidade do Estado como garantidor de direitos e delegando essa função ao mercado. A cidadania, sob ponto de vista individual, é marcada por ausência de debate político sobre as causas mais profundas das desigualdades sociais, como a distribuição de renda.

Ainda que a compreensão de cidadania seja deturpada, a sociedade civil se insere no projeto da democracia nacional por fatores como a possibilidade de voto e a concordância de que a população e o Estado devem caminhar juntos para que a democracia se aprofunde. Entre os espaços democráticos para o diálogo, a sociedade vale-se de Orçamentos Participativos e Conselhos Gestores de Políticas Públicas. Essa participação não pretende acabar com o papel do Estado, mas, sim, “[...] reivindicar e lutar para que este cumpra o seu papel de propiciar, universalmente, educação, saúde e demais serviços sociais com qualidade” (FERNANDEZ; MENDES, 2007, p. 50).

Contudo, um dos principais entraves no amadurecimento da democracia em nosso país é o pensamento recorrente de que a sociedade civil tem uma concentração de virtudes democratizantes e que o Estado seja a encarnação do mal, segundo Dagnino (2004). Tal visão impede a participação política e a integração entre os dois segmentos, uma vez que, no Brasil, estas rivalidades se dão pelas constantes desavenças ao longo da história, conforme articulou Carvalho (1996).

Dagnino (2004) argumenta que uma das relações que mais aumentam o fosso entre relação Estado / sociedade civil é a relação entre Estado e organizações não-governamentais (ONGs). Na visão da autora, tal relação é colocada como modelo de confluência perversa ou ruim, porque o Estado transfere sua responsabilidade para a sociedade civil. E, embora as ONGs tragam resultados positivos, as mudanças são fragmentadas e pontuais, já que não apontam para a diminuição da desigualdade social e a melhoria das condições de vida dos setores sociais atingidos.

Já outro entrave, apontado por Abreu (2003) e Saes (2000), é o de que, na América Latina, o exercício da cidadania é dificultado pela atuação da justiça. Nos países deste continente, a lei é bastante severa para os mais pobres enquanto que permite uma isenção de cumprimento da lei para as classes privilegiadas.

Ainda com tais dificuldades, a participação da sociedade civil no país passou a crescer a partir dos anos de 1980, com a Constituição de 88. E, a partir dos anos de 1990, tais demandas começaram a se concretizar (FERNANDEZ; MENDES, 2007). Dagnino (2004) 
acredita que as tensões e interlocuções entre Estado e sociedade civil fortalecem o exercício da cidadania, porque essa interlocução entre Estado - majoritariamente neoliberal -, e o projeto participativo da sociedade civil aumentam as possibilidades de atuação de setores da sociedade junto ao Estado. E que, embora historicamente conflituosa essa consolidação é possível, porque se tem, no Brasil, um projeto democrático amadurecido, criado a partir de uma sociedade civil razoavelmente consolidada e capaz de inspirar e criar novos princípios.

Outra dificuldade no processo democrático nacional é o de compreender se determinado projeto político é alinhado aos interesses do projeto neoliberal ou da democracia participativa. Na visão gramsciana, entende-se projeto político como o “[...] conjunto de crenças, interesses, concepções de mundo, representações do que deve ser a vida em sociedade, que orientam a ação política dos diferentes sujeitos” (DAGNINO, 2004, p. 98). Isso porque, como salienta o autor, as já conhecidas divergências entre o projeto neoliberal e a democracia participativa, com suas tendências e alinhamentos opostos e até antagônicos, acabam por adotar a mesma retórica e os mesmos termos, ainda que com propósitos distintos, uma vez que ambos os sistemas políticos exigem a

[...] participação de uma sociedade civil ativa e propositiva [...] Nessa disputa, onde os deslizamentos semânticos, os deslocamentos de sentido, são as armas principais, o terreno da prática política se constitui num terreno minado, onde qualquer passo em falso leva ao campo adversário. (DAGNINO, 2004, p. 97).

Assim, por exemplo, no projeto neoliberal, pode haver uma apropriação de conceitos usados na promoção de uma democracia participativa, com a finalidade de se adequar às necessidades liberais.

A autora considera que a cidadania em contexto nacional possui um laço constitutivo entre cultura e política, e, portanto, deve ser encarada não só como estratégia política, mas como política cultural. A autora possui como proposta a concepção de uma nova cidadania, isto é, “[...] de um direito a ter direitos, [...] e que inclui a invenção/criação de novos direitos, que surgem de lutas específicas e de suas práticas concretas” (DAGNINO, 2004, p. 104). A autora reitera a necessidade de a sociedade participar e se incluir em um sistema político já dado, para se integrar à invenção de uma nova sociedade. Por cultura, entende-se “[...] concepção do mundo, como conjunto de significados que integram práticas sociais” (DAGNINO, 2004, p. 104), e que não pode ser entendida adequadamente sem a consideração das relações de poder embutidas nessas práticas. Por fim, salienta a emergência de uma visão ampliada de cidadania, não mais confinada nos limites da relação com o Estado, ou entre 
Estado e indivíduo, mas que “[...] deve ser estabelecida no interior da própria sociedade, como parâmetro das relações sociais que nela se travam” (DAGNINO, 2004, p. 105).

Pelo contexto acima apresentado, nota-se que, no Brasil, ao contrário do esquema marshalliano, os direitos não foram desenvolvidos na mesma cronologia: em território nacional, ocorreu um processo de avanços e recuos políticos, ao invés de uma linha contínua e ascendente. Soma-se a isso o fato de que os eventos históricos mostrados pelos autores confluem para que se entenda que, nos países capitalistas, as classes dominantes se movem para um ataque aos direitos sociais. E, no Brasil, como ressalta Saes (2000), tal movimento é mais fortalecido, pois o leque de direitos sociais é menor e menos amplo, além do fato de a capacidade de resistência das classes trabalhadoras às políticas neoliberais ser regularmente muito inferior.

Merecem destaque os dois pontos reforçados por Dagnino (2004), que orientam no entendimento da cidadania no Brasil: uma construção democrática que conecta cultura e política; e o fato de que o uso inapropriado dos termos pode trazer significações distorcidas e até mesmo opostas. Nesse jogo de termos e conceituações no estabelecimento da nova cidadania, bem como a relação entre política e cultura, entra o estratégico campo da comunicação. Essas duas questões confluem para que se detecte a importância para a informação na construção da cidadania, tema do tópico seguinte.

\subsection{A informação como promotora da cidadania}

Com base nas obras examinadas, parte-se da premissa de que existe uma relação direta entre a construção dos direitos de cidadania e a comunicação plural e democrática. Há autores que consideram e enfatizam a informação “[...] um direito humano, e o direito à verdade das informações [...] e implica a necessidade [...] de não ser enganado, excitado ou perturbado por uma propaganda maciça e deformadora.”, como Bobbio (1992, p. 34). Já Heller (2008) coloca a informação como um atributo para a confiança, uma vez que toda confiança se apoia no saber. Para tanto, quanto mais conhecimento se tiver à luz da teoria, mais se pode argumentar de maneira plena, bem como tomar decisões em prol não só do eu particular, mas do ser humano genérico. Marshall (1963) também afirma que a explicação para um fenômeno, ou seja, o esclarecimento acerca dele, é um dos principais motivos para a sociedade se mobilizar e objetivar um projeto social partindo do consenso. Após essas considerações iniciais, mostrase necessário compreender o processo de reconhecimento da informação como elemento principal à cidadania. Para tanto, o presente tópico contextualiza os eventos históricos, que 
colocaram a informação como elemento central no advento de uma nova concepção de sociedade: a sociedade de massas, que é abordada no primeiro tópico, com os pensamentos de Martín-Barbero (1997) em sua obra 'Dos Meios às Mediações', bem como os de Gentilli (2005). Em seguida, aborda-se a importância da comunicação como valor para a cidadania, também com Gentilli (2005), bem como as afirmações de Arendt (1973), Koshiyama (2005) e outros teóricos.

\subsubsection{Sociedade de grupos $\mathrm{x}$ sociedade de massas}

Na sociedade contemporânea, estudiosos da comunicação e da cidadania colocam a informação como elemento central na consolidação dos direitos humanos. Contudo, essa importância não se deu de maneira automática, mas integrou um processo que se iniciou após o século XIX, com o advento de um novo movimento: a sociedade de massas.

O primeiro pensador do termo “massa” foi Tocqueville, que, no século XIX, definiu-a como um movimento que afeta a estrutura profunda da sociedade. $O$ filósofo Tocqueville ( $1951^{5}$ citado por MARTÍN-BARBERO, 1997, p. 55), contrário à democracia, colocava esse novo movimento como a "ditadura da maioria", o que conduziria, inevitavelmente, à “autodegradação da sociedade” ou a "mediocridade coletiva”. Essa profunda alteração social, antecipada por Tocqueville, surge após a dissolução da estrutura constituída por grupos, isto é, as categorias homogêneas da estruturação da sociedade e que são sempre articuladas e estratificadas.

A massa, ao contrário, tem uma relação heterogênea de estruturação, e pode ser articulada ou não (HELLER, 2008, p. 96). Para Heller (2008, p. 70) a sociedade de massas nada mais é do que uma expressão metafórica para descrever uma sociedade conformista manipulada. Gentilli (2005) e Martín-Barbero (1997) complementam a visão de Heller (2008) ao salientarem as diferenças entre comunidade e massa. Gentilli (2005) contrapõe as diferenças entre uma sociedade de públicos e uma sociedade de massas. Na primeira concepção, existe a opinião pública e a possibilidade de discussão, em que, após a opinião de uma das partes vencer, “[...] os representantes recebem instruções para colocá-la em prática, o que prontamente fazem”, segundo Mills (1981 citado por GENTILLI, 2005, p. 60). Já na sociedade de massas, os homens são constrangidos e ansiosos, por conta das relações inseguras - situação que possibilita que a massa seja facilmente manipulada pelas elites do poder. Essa passagem de uma comunidade de públicos para uma sociedade de

\footnotetext{
${ }^{5}$ TOCQUEVILLE, A.De le democratie em Amérique. Paris: Gallimard, 1951. v. II, p. 215.
} 
massas acontece com os meios de comunicação no centro dessa mudança, atuando como mediadores de uma situação de tensão e ansiedade.

Martín-Barbero (1997) também aponta que as comunidades são psicologicamente confortadoras e inspiradoras, e possuem laços estreitos e concretos, bem como relações de solidariedade, lealdade e identidade coletiva. Por outro lado, as sociedades de massa são psicologicamente angustiantes e favorecem a tensão, já que há uma predominância “[...] da razão manipuladora e ausência de relações identificatórias do grupo [...] ausência compensada pela competência e controle” (MARTÍN-BARBERO, 2009, p. 60). O autor designa como “massa” o modo como as classes populares vivem as suas novas condições de existência, tanto em relação às novas preocupações advindas dessa condição, quanto em relação às novas aspirações com o advento da democracia. Essa angústia, que se deu pela desintegração do público, será ocupada “[...] pela integração que produz o massivo, a cultura de massa” (MARTÍN-BARBERO, 2009, p. 174).

Com a cultura de massa, até mesmo a noção de cultura fora modificada. No século XVII, o termo cultura era concebido como um valor que “[...] se tem, ou melhor, que só alguns têm ou podem aspirar a ter” (MARTÍN-BARBERO, 2009). Em contrapartida, o termo 'cultura de massas’ coloca a cultura não mais como uma definição das diferenças sociais, mas, sim, “[...] o lugar onde tais diferenças são encobertas ou negadas”. (MARTÍN-BARBERO, 2009, p. 174).

Martín-Barbero (1997) enumera os diversos intelectuais que abordaram o sentido de “massa.”. Ortega y Gasset (1987), por exemplo, distingue 'massa' da 'elite cultural e distinta', sendo a massa ou o popular considerada vulgar e conformista. Esse tipo de raciocínio se tornava a justificativa para a elite intelectual e financeira mostrar-se superior e distanciar-se das massas, por meio da adoção de mecanismos como a ciência e a tecnologia. Por outro lado, no desenrolar do século XX, uma visão mais otimista foi se formando a respeito da sociedade de massas. Se considera que as novas circunstâncias são potencialmente libertárias, emancipatórias, isto é, 'otimistas'. Nota-se a existência de dois tipos de pensamento: o pensamento conservador, que não aceita a participação das massas na sociedade; e o pensamento progressista, que acredita na emancipação humana para participar da vida social de modo pleno (GENTILLI, 2005, p. 78).

Essa visão antagônica pode ser encontrada principalmente entre intelectuais europeus e norte-americanos, que perceberam a cultura de massas de maneiras distintas. No Velho Mundo, os intelectuais consideraram o advento da sociedade de massas a representação da morte da cultura. Mas, para “[...] os teóricos norte-americanos dos anos 40-50 a cultura de 
massas representa a afirmação e a aposta na sociedade da democracia completa" (MARTÍN-BARBERO, 2009, p. 57). Os norte-americanos consideravam que, quanto mais acessível fosse a cultura, mais democrática ela seria, uma vez que a comunicação de massa atuaria como facilitadora da circulação da informação entre os diferentes estratos da sociedade.

No entanto, esse discurso progressista representa também uma sociedade com ausência de instituições nacionais bem definidas e de uma "classe dirigente consciente de o ser, se amalgamou através dos meios de comunicação de massa”, conforme aponta Daniel Bell (1969 ${ }^{6}$ citado por MARTÍN-BARBERO, 1997, p. 192). Os Estados Unidos constitui-se na nação que representa, de forma plena, uma sociedade com ausência de um amálgama cultural e identidade nacional, cuja conexão se dá pelos meios comunicacionais. Tal supremacia dos meios de comunicação na sociedade norte-americana se propaga pelo globo, proliferando uma nova concepção de informação, “[...] consagrando o valor de intercâmbio da notícia, ao mesmo tempo mercadoria e comunicação civil, horizontal frente a qualquer autoritarismo” (MARTÍN-BARBERO, 1997, p. 195, grifo do autor).

A notícia, convertida em produto, assume o poder de perpetrar qualquer esfera, “[...] ampliando progressivamente a definição do público, absorvendo e atenuando as diferenças e contradições de classe, e detendo-se [...] no limite extremo da tolerância média do público mais amplo possível” (MARTÍN-BARBERO, 1997, p. 195).

A consolidação da cultura de massas alterou o estilo de vida das sociedades, visto que, a partir de tal advento, a função mediadora dos estilos de vida não se dá mais pelos ditos velhos redutos da ideologia - como a família ou a escola -, e sim pelos meios de comunicação de massa. Com isso, “[...] os mentores da nova conduta são os filmes, a televisão, a publicidade, que 'começam transformando os modos de vestir e terminam provocando uma metamorfose dos aspectos morais mais profundos”” como aponta Bell (1969 citado por MARTÍN-BARBERO, 1997, p. 58). Essa metamorfose é positiva para o mercado - afinal, ele se sustenta pela mudança, instabilidade e pelos valores e padrões mutáveis, de maneira cada vez mais rápida.

O autor considera que o advento da sociedade de massas acarreta no deslocamento da era da produção para a era do consumo. Mas, a consolidação e o advento da cultura de massas não se deram como ruptura repentina: foi gerado segundo Martín-Barbero (1997) lentamente e a partir do popular. E tal dinâmica das massas para a homogeneização de valores, os interesses e o estilo de vida tem seu verdadeiro alcance na atualidade, por meio de um

\footnotetext{
${ }^{6}$ Bell, D. et al. Industria cultural y sociedad de masas. Caracas: Monte Ávila, c1969. 281 p.
} 
processo de destruição das culturas regionais, com sendo a construção de uma cultura transnacional. A questão transnacional representa uma nova fase do desenvolvimento do capitalismo, em que o campo da comunicação passa a ter um papel decisivo, porque “[...] o que está em jogo agora não é a imposição de um modelo econômico, e sim o ‘salto’ para a internacionalização de um modelo político” (MARTÍN-BARBERO, 1997, p. 285, grifo do autor).

E, como a transnacionalização atua principalmente no ramo das tecnologias da comunicação, é dentro da área de comunicações onde as questões nacionais se veem em seu ponto de fusão (MARTÍN-BARBERO, 1997). Com base nesses pensamentos, o autor enfatiza sua teoria, a de colocar a cultura como campo primordial na batalha política e no centro do cenário político e social. Isto porque sua dimensão simbólica, isto é, para Martín-Barbero (1997) sua capacidade de representar o vínculo entre os cidadãos, o sentimento de pertencer a uma comunidade é instrumento ideal para enfrentar a “erosão da ordem coletiva”.

De acordo com o autor “[...] há uma reavaliação do cultural: o campo estratégico na luta para ser espaço articulador dos conflitos.” (MARTÍN-BARBERO, 1997, p. 105). Já a mídia, por mediar as relações entre política e cultura, possui papel central na sociedade, visto que o meio não se limita mais a veicular ou a traduzir as representações existentes, nem tampouco a substituí-las, mas começou a constituir uma cena fundamental da vida pública, conforme ressalta Martín-Barbero (1997).

Ainda que seja parte fundamental do elo entre cultura e política, a importância da comunicação se consolida se os meios forem concebidos como formas de práticas culturais e de criatividade social. Outro ponto importante é que a democracia participativa real só ocorre se tiver uma comunicação massiva, ou seja, se determinado assunto estiver na agenda pública da sociedade. Sem a comunicação massiva, não é possível existir uma democracia participativa, porque a cena pública que se trava nos meios de comunicação é essencial no entendimento dos fatos. Afinal, a sociedade está dispersa, e as informações de que necessita são sempre recebidas de maneira mediada, isto é, via meios de comunicação.

Pode-se inferir que a importância da informação se dá porque, sem ser informado em meio a tantos dados dispersos da sociedade da informação, o cidadão não adquire discernimento para o que deve ser discutido na esfera pública, cuja finalidade é ampliar os direitos do homem genérico e não somente seus direitos e necessidades individuais. A consolidação de uma mídia plural, que vise à cidadania e à ampliação do espaço público de discussão, faz-se necessária em uma sociedade que se conecta pelos dispositivos midiáticos. 
Essas e outras questões apontam para a importância da informação na consolidação dos direitos de democracia, cuja abordagem consta no tópico a seguir.

\subsubsection{Informação como valor para a cidadania}

Da mesma maneira que Martín-Barbero (1997), Gentilli (2005) coloca que, em uma sociedade "progressista-evolucionista", com sua cultura democrática, os meios de comunicação de massa reforçam a democracia a suas instituições, e não o contrário. Para Gentilli (2005), o direito à informação pública é um direito de cidadania, e a comunicação ideal é aquela que procura passar informações que visem à cidadania, isto é, ao bem público. Atuando como uma instituição da sociedade civil, a importância da imprensa se dá, principalmente, porque suas implicações, efeitos e consequências incidem diretamente sobre o interesse público.

O autor retoma conceitos de cidadania e dos direitos do homem, sob uma perspectiva política, ressaltando a centralidade do direito à informação para a garantia dos direitos humanos e da democracia. Por democracia, entende-se um movimento caracterizado por um conjunto de regras que “[...] estabelecem quem está autorizado a tomar decisões coletivas e com quais procedimentos”, como descreve Bobbio (1986 citado por GENTILLI, 2005, p. 112). Numa democracia, os direitos relativos à esfera pública integram o direito à liberdade de opinião e expressão, de liberdade de imprensa e liberdade de reunião e associação.

Gentilli (2005) acredita que é possível popularizar a democracia, com base no fortalecimento dos procedimentos democráticos, a fim de que se assegurem as decisões públicas. Mas, para fortalecê-los, é necessário levar em consideração duas premissas. A primeira para que

[...] aqueles que desejem ser votados tenham ampla liberdade de manifestação, expressão e organização partidária. [...] E a outra premissa refere-se àqueles que irão escolher seus representantes, para que façam [...]sua escolha sem constrangimentos e com condições de optar, baseados no conhecimento de todas as alternativas colocadas em disputa”. (GENTILLI, 2005, p. 116-117).

Outra questão que se deve levar em conta é que, como a sociedade atual é dispersa, os diversos procedimentos de democracia, para se efetivarem, necessitam de procedimentos sociais de mediação, o que caracteriza as especificidades do chamado direito à informação. Nesse sentido, tem-se que o direito à informação não como um direito civil, político ou social, como fora mostrado anteriormente, mas sim, um direito-fim, um direito no qual se realiza a si 
mesmo. Um exemplo da importância da informação é na decisão de voto: para saber as possibilidades e os candidatos, o cidadão necessita de mediação e de ser informado sobre as alternativas possíveis.

Alicerçada nessa linha de pensamento, a concepção central de Gentilli (2005) é a de que a informação é, ao mesmo tempo, direito civil, social e político. Isso porque a informação é um direito-meio para o exercício de outros direitos, já que dá acesso aos instrumentos necessários para que o indivíduo saiba quais são seus direitos civis, políticos e sociais. Sabese que as informações indispensáveis para a vida em sociedade chegam, na contemporaneidade, de maneira mediada e não diretamente, como acontecia nos primórdios da democracia. Desse modo, “[...] o direito à informação é a porta de acesso a outros direitos, uma vez que assegura os direitos de cidadão” (GENTILLI, 2005, p. 122). Portanto, todos os direitos são conectados ao direito à informação, visto que o aumento da participação cidadã prevê um aumento ao acesso à informação relativa à esfera pública.

Numa sociedade democrática, o acesso às informações imprescindíveis à vida permite que o cidadão tenha melhores condições para "poder formar suas próprias referências particulares, fazer suas escolhas e julgamentos de modo autônomo” (GENTILLI, 2005, p. 130). E o cidadão, na medida em que tem ciência de seus direitos, passa a exigir novas demandas sociais, gerando um ciclo que fortalece a democracia.

Contudo, um dos problemas centrais relativos ao direito à informação não é mais garantir tais liberdades: a problemática atual é como conceber, nas sociedades massivas contemporâneas, “[...] um modelo de estrutura de comunicações que seja pluralista, livre, amplo e acessível à população” (GENTILLI, 2005, p. 123). O dilema para Gentilli (2005) é garantir o imperativo democrático de dar publicidade àquilo que é público, de tornar público, visível, transparente, os fatos relativos à esfera pública. Nesse sentido, tem-se a importância de se lutar pelo direito à informação, que consiste num direito que “[...] assegura outros direitos, confere condições de igualdade de sujeitos e oferece visibilidade ao poder e ao mundo”. (GENTILLI, 2005, p. 128).

Com a pluralidade de discursos, amplia-se o direito emancipatório que é o direito de liberdade de escolha, de o ser humano tomar decisões autônomas baseadas em seu senso crítico numa pluralidade de discursos. Para assegurar a pluralidade, Gentilli (2005, p. 132) acredita que é o Estado que deveria fornecer informações “de forma tutelar ou regulamentar”, da maneira que fornece - “ou deveria fornecer” - saúde, educação ou outros serviços sociais. Essa visão permite conceber o direito à informação como uma extensão do direito à educação 
e direito à saúde, que são, dentro da perspectiva social, elementos necessários e úteis “[...] para a manutenção da vida humana em sua dignidade mínima” (GENTILLI, 2005, p. 131).

Além de situar a informação como elemento vital na sociedade, considera Gentilli (2005) que, ao elevar a informação a esse patamar, torna-se dever do Estado fornecer informação pública, de maneira que propague, universalmente, os benefícios adquiridos por nossa civilização. E quem realiza a função de mediar e filtrar a informação é o jornalista, que, como cidadão, atua como representante da sociedade civil.

Com isso, sua função seria de um mediador que filtra, seleciona e organiza os elementos e “as informações necessárias para o julgamento do leitor”. A ampliação de possibilidades, mostrada pelo jornalismo cidadão, torna-se o “[...] combustível para o aprofundamento democrático e a melhoria na própria qualidade do serviço que está sendo oferecido [...] e os meios de comunicação funcionariam como um elemento que rompe a inércia na direção a uma ampliação de direitos” (GENTILLI, 2005, p. 149-151).

Gentilli (2005) acredita que o direito à informação é conquistado conforme as demandas de cidadania, e não por políticas de controle. Isso porque o cidadão, ao participar da sociedade que integra e ter mais noções de seu papel social, passa a exigir informações com maior aprofundamento e qualidade. A exigência de “[...] uma melhor qualidade de informação se coloca como uma exigência de consumidor, mas incorpora de qualquer modo outros direitos” (GENTILLI, 2005, p. 151). Não se defendem políticas de controle dos meios, mas, sim, de regulamentação. Um exemplo é o Código de Defesa do Consumidor, uma série de regulamentações que também deveria existir no trabalho jornalístico, a fim de proteger o cidadão do “jornalismo enganoso”.

A democratização da comunicação não implica em apenas combater os monopólios, mas sim em ampliar a exigência por parte de cada cidadão, ao situarem-se como “consumidores de informação” - afinal, quem consome a informação também é o indivíduo comum, e não somente os financiadores. Em uma sociedade democrática, a prática do jornalismo compete em possibilitar que o profissional da informação tenha acesso aos poderes e difunda a cidadania. Mas, essa prática, considerada a ideal, não se concretizará plenamente enquanto existir a posse privada dos meios e enquanto a sociedade civil não realizar uma pressão para exigir uma qualidade informativa. Ou seja, os detentores dos veículos de comunicação terão que ser pluralistas por meio de pressões contrárias, que exijam uma cobertura mais diversificada e que acompanhem os diferentes movimentos da sociedade.

Apesar da visão de que a informação é elemento essencial à vida humana na sociedade contemporânea, Gentilli (2005, p. 66) aponta que “apenas a informação não é suficiente para 
que indivíduos, as pessoas que compõem a massa, formem posições autônomas e livres das manipulações das lideranças.” Para o autor, a mídia é articulada a outros subsistemas, ou seja, nem sempre a massa de indivíduos reconhece e interage com os fatos informados. Um regime totalitário ou entraves burocráticos, por exemplo, podem gerar “[...] reações como a apatia, a indiferença e até mesmo a hostilidade” (GENTILLI, 2005, p. 65), diante das questões da esfera pública. Se as reações anteriormente mencionadas predominam no imaginário coletivo, o indivíduo pode até estar absolutamente bem informado, mas a imprensa pouco pode modificar a apatia existente.

Além da articulação dos veículos comunicacionais a outros sistemas e da problemática do monopólio dos meios, outra questão apontada é um excesso de informações comprimidas e cada vez mais espetacularizadas. Como consequência, os acontecimentos se tornam cada vez mais opacos, já que ocorrem simultaneamente, disputam a atenção do indivíduo e parecem cada vez mais descontextualizados. Sabendo da tendência ao excesso e à descontextualização, Gentilli (2005, p. 163) conclui ser necessário que o jornalismo cidadão oriente o homem moderno, para que ele se localize no mundo e no seu território nacional, mostrando suas circunstâncias e realidades, e situando-o a partir do conhecimento do volume de oportunidades que lhe são oferecidas, para que tome suas decisões e faça suas escolhas, a respeito dos assuntos que lhe interesse.

Outra autora que também trabalha o direito à informação é Arendt (1973), que considera o direito à informação como a mais essencial liberdade política e entende que a imprensa é livre e idônea, pois "tem uma função enormemente importante a cumprir e pode perfeitamente ser chamada de quarto poder do governo” (ARENDT, 1973, p. 46). Seu pensamento é articulado com base em eventos históricos, como os crimes de guerra cometidos na Guerra do Vietnã que foram desmascarados pela imprensa, e constituíram um marco na atuação da mídia na busca da verdade.

Pelo exemplo da Guerra do Vietnã, Arendt (1973, p. 20) pretende ressaltar que existe a possibilidade real de se esconderem fatos históricos por meio da omissão da informação. Isso se dá porque os detentores do poder e os homens atuantes na cena política, ao sentirem-se donos de seus próprios futuros, ficam eternamente tentados a se fazerem donos do passado também. Sem a investigação midiática e as pressões da sociedade civil, os detentores do poder naturalizam a manipulação como algo que “[...] dirige a mente das pessoas e portanto é o que realmente dirige o mundo[...]” (ARENDT, 1973, p. 25).

Segundo a autora, ainda existe a concepção, entre os que ocupam cargos eletivos, de que todos os indivíduos são passíveis de serem manipulados. E que, se bem feita, uma mentira 
pode ser guardada na história, principalmente se tal mentira for contada pelos intelectuais que utilizam de cálculos “pseudomatemáticos” e métodos precisos para mascarar a realidade. Há entre os 'resolvedores de problemas', “[...] uma arrogância do poder - a busca de uma mera imagem de onipotência. Isso se dá, porque os resolvedores de problemas não precisam saber dos fatos históricos ou de informação, mas têm uma teoria que todos os dados que não se ajustavam eram negados ou ignorados” (ARENDT, 1973, p. 41-42).

Ainda que tenham esse pensamento, os mesmos detentores do poder sabem da atuação da imprensa e que nem todo veículo é totalmente atrelado a interesses privados. Isso se dá porque, quando os meios de comunicação descobrem algo que o governo/instituição tenta esconder e que é de interesse público, confirma-se a integridade e o poder da imprensa, legitimando seu papel social. Contudo, fica claro que os grupos do poder tentaram e tentarão esconder fatos e erros históricos, articulação esta que pode ser ainda mais recorrente se a imprensa estiver atuando em conformidade com determinado grupo político.

No contexto brasileiro, outro entrave à democratização é a ausência de debate a respeito da regulamentação da mídia. Conforme articulou Lima (2012) ${ }^{7}$, viveu-se, até a redemocratização, sob o temor da censura dos meios midiáticos, uma censura estatal que atualmente não ocorre. A problemática atual é a hegemonia de pensamento e discurso dos monopólios comunicacionais, gerando um déficit de vozes plurais da maioria da população. Em essência, há uma falta de inserção das minorias e outros grupos no debate público e na esfera pública, restringindo a pluralidade do debate.

No atual momento histórico, se faz necessária uma regulamentação estatal, porém, não com objetivos de censura, mas sim para permitir que outros grupos da sociedade civil participem do debate público exposto na mídia. Nesse sentido, a interferência do Estado na mídia ampliaria a liberdade de expressão para minorias raciais, étnicas, religiosas, feminina, entre outras. É notório que a pauta do debate público continua monopolizada pelos grandes meios de comunicação, demonstrando outro dilema, “[...] que é o de estar no espaço público (possibilidade que aumentou com a internet), e ser ouvido no espaço público (o que é, normalmente, conseguido somente pelos meios massivos)” (LIMA, 2012, grifo nosso).

Assim, a polêmica colocada por Lima (2012) é que, em consequência da intervenção estatal, a ampliação da participação de outras vozes na política e no espaço público do Brasil impedirá quem (ou quais grupos) de falar sozinho e vai possibilitar quais vozes despontarem. Uma pressão pública de outras vozes da sociedade civil pode possibilitar e promover avanços na legislação, sobretudo quando se trata dos direitos sociais. Contudo, para saber que tipo de

\footnotetext{
${ }^{7}$ Notícia fornecida por Venício Artur de Lima, durante a XIV Jornada Multidisciplinar - Mídia e Cidadania, em Bauru, em 22 de maio de 2012.
} 
direitos o homem possui, deve-se ter uma informação cidadã, que se constitua em instrumento de agendamento do discurso público e de ação para a cidadania. Por fim, Lima (2012) argumenta que, se plenamente contextualizado, salientar que o direito à comunicação afeta 0 cotidiano das pessoas pode ser a principal estratégia de mobilização para uma regulamentação dos meios de comunicação.

No que tange ao indivíduo que produz a informação, pode-se valer das reflexões de Abreu (2003, p. 26), que também considera que os meios de comunicação possuem a responsabilidade de mediar grande parte das informações indispensáveis ao exercício da cidadania. Ainda que apenas recentemente o direito à informação alcançasse status de elemento fundamental no estabelecimento dos direitos do cidadão.

Para a autora (ABREU, 2003), mesmo que a imprensa seja a principal articuladora para alargar conhecimento sobre questões públicas, é o jornalista cidadão quem deve ter ciência de que sua ação precisa servir aos interesses concretos dos cidadãos, de maneira que responda aos questionamentos e às preocupações dos leitores e da audiência.

Com base nesse compromisso social, o comunicador, tendo ciência de seu papel como cidadão e mediador entre a informação a ser dada como relevante ou não, tem o dever de considerar a informação como modo de criar condições para que o indivíduo consiga formar suas próprias referências, escolhas e julgamentos. Para que o jornalista cidadão atue, bem como revele as questões que seu senso crítico quer destacar em prol do fortalecimento da democracia, deve ocupar espaços nos mais diversos meios de comunicação e se apropriar dos lugares disponíveis.

No entanto, assim como Abreu (2003 citado por GENTILLI, 2005) acredita, os veículos informacionais podem ter impacto sobre determinado público, mas estar articulados a outros subsistemas. Portanto, podem interferir na dinâmica das esferas da sociedade, porém sempre sob certas condições e circunstâncias específicas. Isso porque as mensagens viabilizadas pela mídia são sempre filtradas por grupos de pertencimento ou líderes de opinião, que podem atuar como protetores ou impedidores das mensagens.

Outro argumento largamente utilizado quando se pensa na não concretização do exercício da cidadania pela informação é a dimensão econômica. Apesar disso, Abreu (2003, p. 39) acredita que tais tipos de preocupações mercantis não justificam uma prática jornalística que inviabilize a promoção da cidadania. Isso porque, mesmo que a dimensão econômica da mídia deva ser considerada, a redemocratização possibilitou uma ampliação da luta pelos direitos de democracia na sociedade brasileira e, desde a redemocratização, a 
sociedade passou a articular-se em busca da justiça e cidadania, luta que se ampliou, nas redações dos jornais, entre os profissionais da imprensa de grande receptividade.

Portanto, tais ressalvas não impedem que a sociedade civil possa cobrar do veículo comunicacional a prestação de um serviço à população, com a propagação de conteúdos que reforcem ou ativem as opiniões do público. A imprensa cidadã, como integrante da sociedade civil, atua como uma “alternativa ao papel do Estado, pois é um representante político da população, ainda que sem mandato eletivo” (ABREU, 2003, p. 39). A autora conclui que esse tipo de jornalismo corresponde a usar um meio de informação para defender valores como rejeição à corrupção, defesa pelos direitos aos cidadãos, igualdade no tratamento e aplicação das leis, dentre outros, demonstrando uma atuação que cobre do Estado a efetivação dos direitos humanos e, ao mesmo tempo, saliente qual o papel do indivíduo dentro de uma sociedade.

Heller (2008) também concorda que a informação, por si só, não é o suficiente para que a sociedade deixe de ser manipulada. Para a autora, a mídia é apenas um membro do corpo composto pela opinião pública. Ou seja, se ela manipula é porque está, na maioria das vezes, atrelada a interesses do grupo político ao qual pertence. Assim, com exceção do comportamento, dado como incógnito dissimulado, em que a pessoa tem consciência da alienação e honestidade dos outros e se aproveita da situação, os demais membros da opinião pública, principalmente os produtores de informação com pouco senso crítico, também são manipulados e reproduzem discursos já prontos.

Quem também se interessa por essa questão é Koshiyama (2005, p. 26), ao destacar que o trabalho do comunicador integra um projeto político e uma ética a serviço do qual “estão os recursos da técnica jornalística.” Deste modo, toda informação não é isenta de valores intrínsecos a um sistema - o sistema político partidário que o veículo comunicacional integra. Portanto, mesmo que um jornalista tenha senso crítico e opinião política. Koshiyama (2005, p. 28) aponta que “[...] quanto ele vai ceder ou desfigurar sua opinião depende do projeto político que ele assume ao trabalhar em um órgão, depende do grau de convergência que consegue estabelecer entre o projeto patronal e o seu”.

Para o mesmo autor, o jornalista tem uma função dentro do órgão, ainda que com as limitações dentro do projeto político do veículo. Mas, o principal problema é a existência de um jornalista sem partido e sem cidadania, que "não admite o direito dos leitores saberem como as matérias foram construídas. Ele não reconhece a relação entre técnica, ética e política” (KOSHIYAMA, 2005, p. 30). 
Com base nas ponderações anteriores, considera-se que a importância da informação se dá, principalmente, pela relação da mídia com a sociedade de massas, que é dispersa e, por isso, precisa da mediação. Porém, essa mediação deve ser consciente e com senso crítico, de maneira que o jornalista cidadão traga à tona os assuntos relevantes para a ampliação dos direitos de cidadania, não só os direitos civis ou direitos voltados para o consumo, mas, principalmente, a ampliação dos direitos políticos e sociais.

Acredita-se também que é possível as massas se emanciparem e adquirirem posição autônoma, a partir do momento em que uma imprensa plural assuma seus valores e seja transparente quanto aos seus posicionamentos ideológicos. Com a pluralidade, ela passa a dispor de um leque de opções informacionais à disposição do indivíduo, que, autonomamente, se informe sobre determinado assunto para o exercício de seus direitos.

\subsection{Cidadania: dada de forma permanente, no cotidiano}

Conclui-se que a cidadania se dá de forma permanente, no cotidiano, como uma construção histórica. E que os direitos, assim como os valores morais, podem evoluir ou decair. Concordando com Heller (2008), consideram-se a cotidianidade e a constância como maneiras de mudar as superestruturas. E, tal cotidianidade, embora seja por vezes considerada despolitizada e irrelevante, na verdade, é que concentra o cerne da mudança política (MARTÍN-BARBERO, 2009).

As mudanças estruturais ou revoluções se dão verdadeiramente com a incorporação de direitos e sua manutenção, em conjunto com a necessidade de se propor outros paradigmas e vias para se reconfigurar modelos de vida. Se os padrões atuais de cidadania estão insustentáveis, devem-se mostrar outras possibilidades, de maneira que se discuta sua aplicação e viabilidade. Sem constância, permanência e novas reconfigurações, a mudança não se dará de forma plena.

Assim como os autores Heller (2008) e Hirschman (1992), Bobbio (1992) salienta o paradigma dos valores que vão e voltam, sendo que alguns valores, fundamentais em determinadas épocas, não são fundamentais em outras épocas e em outras culturas. O mesmo se aplica aos direitos de cidadania: tal quais os teóricos anteriormente mencionados, Saes (2000) acredita que alguns direitos se desenvolveram mais plenamente do que outros na sociedade capitalista. E, nestas sociedades, os direitos sociais podem passar por períodos ou situações em que estejam declinantes ou mesmo ausentes. 
O curso da história não é evolucionista ou linear, assim como a extrema esquerda com seu discurso reacionário tentam prever (HIRSCHMAN, 1992). O pensamento de um percurso evolucionista de cidadania, como fora colocado por Marshall (1963), representa um conforto tanto para esquerda como para a direita, mas os eventos históricos demonstram que isso não ocorre. Tal olhar fatalístico e naturalizado das estruturas de nossa sociedade não é verdadeiro - as coisas aconteceram porque foi possível acontecerem, não que fossem inevitáveis (HELLER, 2008). Esse reconhecimento demonstra a importância de se conhecer a trajetória da inserção de direitos em um país, para que as próximas gerações saibam os fatos e ações e consigam seguir adiante com as novas demandas da cidadania da terceira geração.

Quanto à construção dos direitos, pode-se inferir que os direitos sociais podem funcionar como instrumentos para barrar algumas liberdades individuais, as quais explicitam o poder de alguns setores; enquanto que os direitos civis estão eminentemente ligados à evolução do capitalismo e ao cerceamento da atuação do Estado, em prol das liberdades individuais. Com isso, os direitos sociais são, de alguma uma maneira, antagônicos e restritivos aos civis (BOBBIO, 1992).

Por conta desse conflito, Saes (2000) acredita que a evolução dos direitos serve mais como paliativa, pois não modifica a essência. Ele afirma que a cidadania é um instrumento do capitalismo para que não se mudem as macroestruturas, pensamento este contrário ao de Marshall (1963), o qual acredita que a cidadania e o capitalismo andam em direções opostas.

Já Hirschman (1992) propõe um diálogo entre a esquerda e a direita, ainda que igualmente acredite que posicionamentos mais radicais também mexam na cidadania. Tanto Hirschman (1992) quanto Saes (2000) concluem que, já que o movimento da maioria social é dinâmico e progressivo, e o da classe dominante é estacionário e regressivo, o processo de criação de direitos na sociedade capitalista é, necessariamente, um processo conflituoso. Existe conflito porque as demandas sociais são reais e motivos de luta: se um grupo conquista algo, o outro perde. No entanto, tal conflito é considerado de forma positiva por Dagnino (2004), visto que fortalece a democracia, possibilitando uma evolução da sociedade e da cidadania pelo uso da palavra.

A história mostra que a burguesia revolucionária se apropriou da cidadania e, em seguida, o fez a burguesia dominante da maneira que lhe conveio, e, atualmente, o conceito é reinventado pelos capitalistas tecnocratas. Estes eventos são considerados positivos por Manzini-Covre (1996), pois possibilita que se entenda que a cidadania, ainda que tenha surgido no contexto da emergência da burguesia, pode ser apropriada e reelaborada pelos trabalhadores. Essa visão otimista tem a ressalva de que a apropriação do discurso sobre 
cidadania também possa cair no esvaziamento, como se a ampliação dos direitos representasse somente um alargamento das possibilidades de consumo.

Como foi observada ao longo do capítulo, a modificação dos termos é alvo de constantes discussões de teóricos como Marshall (1963), Dagnino (2004) e Hirschman (1992). Isso porque, sabe-se que a apropriação dos termos, conforme os interesses, é um recurso utilizado tanto para desmobilizar a ação como para atingir determinado objetivo específico por parte de quem produz a informação ou da organização a que pertence.

Marshall reitera que em sociologia, “[...] há a possibilidade de que o rótulo permaneça mesmo quando já não seja apropriado” (MARSHALL, 1963, p. 184). E, assim como a sociedade muda, os termos mudam, e a apropriação das palavras é modificada concomitantemente com a mutação da própria história. Na contemporaneidade, por exemplo, Dagnino (2004) anuncia que a visão neoliberal capturou termos contrários aos neoliberais para falar por eles e para eles.

Um exemplo das mudanças da significação de termos foi dado por Hirschman (1992). Ele ressalta que, em seus primórdios, a palavra democracia instigava reações negativas aos conservadores, de maneira similar quando se pronuncia, hoje, a palavra comunismo. E tal preocupação não é infundada: se o uso destes termos é tão relevante, em uma sociedade mediada, os principais articuladores da significação dos termos é a imprensa. Por isso, é necessário um comunicador com senso crítico e aparato teórico para entendimento do que significa cada conceito usado na construção de seu material comunicativo. Se não houver conhecimento sobre o significado e apropriação dos termos, ocorre a deturpação, que leva à opinião pública um conceito de cidadania que pode refletir uma visão unilateral, atrelada a interesses de determinado grupo social.

Vale salientar as visões similares de Arendt (1973), Gentilli (2005), Abreu (2003) e Heller (2008) de que a informação, por si só, não muda as estruturas. A burocracia, como colocou Saes (2000), e a apatia política gerada, por exemplo, por regimes políticos totalitários - como ressaltou Gentilli (2005), acarretam também uma ineficácia informacional, por mais que a imprensa difunda informações verídicas e que promovam a cidadania. Ainda assim, não se deve eximir a responsabilidade da mídia na geração de um círculo vicioso de apatia quanto à esfera pública. A conjuntura midiática atual consiste em dilemas como a omissão de determinados assuntos, muitas vezes de interesse público, dando ênfase a assuntos da esfera privada, que pouco altera o cotidiano do indivíduo. Ou, ainda, na informação desconectada do cotidiano do cidadão, com um crescente volume de notícias, contraditórias entre si, e que podem gerar uma descontextualização de fatos que estão, de fato, conectados. 
Essa descontextualização é reflexo de uma sociedade dispersa que, desintegrada das classes sociais, não consegue conceber que faz parte da mesma situação e que integra um sistema em que todos pertencem à mesma conjuntura macrossocial. Como consequência, apontada por Marshall (1963) e Martín-Barbero (1997), os indivíduos não se unem em prol das mesmas causas, competindo entre si pela visão individualista.

Para reverter o quadro, uma estratégia colocada por Lima (2012) refere-se à importância de inserir a notícia e o fato no cotidiano do indivíduo, para que ele se mobilize em prol de alguma ação, visto que o jornalismo lida com um evento singular que pode ser problematizado. Mas, para tal estratégia se viabilizar e ser garantida é importante uma regulamentação da mídia. Se, antes da democratização, a luta era para garantir a liberdade de imprensa, hoje, com a consolidação da democracia, é notório que a imprensa brasileira é livre de censura estatal, mas encontra-se concentrada e sem abertura à pluralidade de vozes. Dessa forma, a questão central é garantir a pluralidade de discursos e a contextualização maior da informação.

Quando não existe regulamentação da imprensa, isto é, quando não se formulam normas, direitos e deveres, os meios e os produtores da informação sentem-se responsáveis para cumprir somente as necessidades e demandas apenas de quem produz e financia seu veículo, ou seja, uma sobreposição dos direitos individuais a uma função social, que é a da comunicação social. Mostra-se, assim, como colocou Martín-Barbero (1997), a legitimação de uma notícia baseada na concepção norte-americana de comunicação, isto é, a notícia vista como uma mercadoria, ausente de qualquer regulamentação, e partindo dos princípios exclusivos dos direitos civis e individuais. A visão de autorregulamentação da mídia, considerada somente após os direitos civis, é a prova de como o exercício da imprensa está articulado a uma visão de mundo calcada no individualismo e nos direitos negativos.

Quando se parte de uma concepção de notícia como produto, permite-se que a comunicação seja feita visando às necessidades de quem financia o veículo, e não do cidadão. Enquanto tal concepção se mantiver, o jornalismo praticado será visto sob ponto de vista de sua manutenção financeira, justificativa que não é absoluta (ABREU, 2003), já que não se pode submeter um direito público e social somente começando desta premissa. Nessa linha de raciocínio, é como se a saúde e a educação só fossem fornecidas a quem possuísse subsídios financeiros e/ou a quem financiasse tais setores.

Tal qual é o pensamento de Martín-Barbero (1997), Dagnino (2004, p. 98) concorda que o Brasil possui um vínculo indissolúvel entre cultura e política, já que os projetos políticos não se restringem à atuação política, mas acabam por expressar e veicular 
significados que integram matrizes culturais mais amplas. E os movimentos da sociedade civil - como os ligados aos direitos humanos e aos movimentos ecológicos de terceira geração (BOBBIO, 1992) - conseguem introduzir "novos sentidos do social e novos usos sociais dos meios” (MARTÍN-BARBERO, 2009, p. 20).

Essa nova relação entre política e cultura centraliza os meios de comunicação no jogo de construções de sentidos e de poder. Isso porque a mídia é, junto com a educação, responsável por colocar a cultura no centro da política, o que viabiliza o poder de criar e recriar termos e significações. Porém, um veículo comunicacional, que tenha noção desse poder, mas que está atrelado somente a interesses privados, pode se empenhar em mascarar certos assuntos, seja por pressão política, de seus anunciantes, seja por outras questões.Tendo ciência disso, a sociedade civil também deve atuar para inserir-se nesse campo tão estratégico, ou seja, democratizar a comunicação (GENTILLI, 2005). Contudo, esse engajamento deve ser também com a proposição de alternativas, não somente combatendo os monopólios e o quadro existente.

Nota-se que diversos teóricos acreditam que a informação é uma forma efetiva de se lutar pelos direitos humanos e para sair de sua esfera individual, voltada às necessidades cotidianas. Quanto à tendência de vislumbrar apenas a sua humanidade, Heller (2008) relembra que o cotidiano é um dos principais fatores que viabilizam o ser humano a enxergar somente sua experiência. E, para sair dessa cotidianidade, Heller (2008) e Bobbio (1992) possuem a mesma visão, que é sair da individualidade para considerar sobre o paradigma do público, ou do ser particular para o ser humano genérico. Dessa forma, é necessário que o ser humano tenha ciência da importância de valores morais, a fim de que não se prenda a valores individuais e egocêntricos.

Pensando na ética, Heller (2008) indica que, com a alternância de valores, é possível que as próximas gerações de indivíduos analisem o comportamento individualista da sociedade atual, de não pertencimento a uma comunidade como garantia de uma pseudoliberdade, e julguem o que estava errado. Espera-se, segundo tais conhecimentos, que chegue um momento em que a ampliação dos direitos do homem, sobretudo os sociais, não seja considerada da esquerda radical ou de progressistas, mas, sim, direitos humanos. 


\section{Comunicação e saúde}

O capítulo apresenta a discussão teórica na comunicação para a saúde, com pesquisa documental de autores que tratam do tema. A revisão da literatura inicia-se com os princípios e o contexto histórico do movimento intitulado 'Promoção da Saúde', com Bógus e Westphal (2007), Fernandez e Mendes (2007). Em seguida, mostra-se um panorama da saúde como produção social, com Minayo (1992), passando pela importância de se vincular a comunicação em saúde como um instrumento na promoção da cidadania, com Kucinski (2000). Um dos resultados apontados é a importância de se efetivar um novo modelo de comunicação que vise à concretização de políticas públicas, conforme Araújo e Cardoso (2007). Por fim, Bueno (1996) traça um panorama da abordagem da comunicação em saúde e elenca dicas de como tratar do tema.

Antes de iniciar o capítulo, vale antecipar que, ainda que se proponha um modelo comunicativo e se estabeleçam novos parâmetros na abordagem da comunicação para saúde, tem-se ciência de que o campo comunicacional integra um contexto sociopolítico. E, no Brasil, pode-se citar como características desse contexto a desigualdade e a ausência de pluralidade de discursos, isto é, características que acabam por impedir, ou ao menos limitar, a atuação do comunicador que aborda saúde. Entre outras limitações de um jornalismo que objetiva articular o conceito de promoção da saúde, vale citar os interesses de diferentes ordens, bem como a ingenuidade do comunicador.

Ainda que tais limitações sejam elencadas, o debate sobre o assunto mostra que se buscam novas discussões e possibilidades na comunicação para a saúde. Soma-se a isso que os entraves anteriormente mencionados correspondem a um embate entre grupos com interesses antagônicos, mas que podem interagir de maneira que se chegue a um consenso em prol do fortalecimento da democracia.

\subsection{Promoção da Saúde: princípios e contextos}

\subsubsection{Promoção da Saúde e qualidade de vida}

Para a pesquisa, na temática da saúde, trabalha-se com o conceito de Promoção da Saúde, movimento despontado nas décadas de 1970 e 1980, que muda a concepção preventiva do processo saúde-doença para um enfoque social e político dos determinantes 
das condições de vida das populações envolvidas. O movimento focaliza a saúde como produção social, marcada por um trabalho de cooperação com outros setores da sociedade e com ações centradas na educação.

A autora Márcia Westphal aponta que a proposta é uma nova forma de refletir sobre a saúde e tornar efetivas as ações que a ela se referem, focalizando a qualidade de vida da população. Nessa concepção, o homem é considerado segundo Westphal (2007, p. 8), “um ser integral, cujo bem-estar físico, mental, social e espiritual é constantemente afetado por fatores biogenéticos, mas também pelo ambiente físico, social, econômico, político e cultural”.

Westphal (2007) destaca dois marcos, que centralizaram a Promoção da Saúde para a pauta de discussão: a Carta de Ottawa, de 1986, no Canadá; e a VIII Conferência Nacional de Saúde no mesmo ano, ocorrida em Brasília. Nestas duas ocasiões, a saúde foi caracterizada não somente como ausência de doença, mas, sim, como a complexidade das questões sociais que afetavam a saúde humana, sendo necessário recuperar o sentimento ético da vida.

No caso do Brasil, tais movimentos contribuíram para que, na Constituição de 1988, fosse incluída uma proposta de mudança no conceito de saúde. Definiu-se então como sendo, segundo Westphal (2007, p. 8),

um direito de todos e dever do Estado, garantida mediante políticas sociais e econômicas que visem à redução do risco de doenças e de outros agravos, além do acesso universal e igualitário às ações e serviços para sua promoção, proteção e recuperação.

Ao mesmo tempo, foi definido que saúde é resultante das condições de vida e trabalho, bem como um estado coletivo que pode ser atingido por meio de políticas econômicas e sociais. Conforme descreve Westphal (2007, p. 9), “[...] com isso, as estratégias para se promover a saúde estão articuladas com os interesses econômicos e de bem-estar social, de saúde e desenvolvimento econômico e social”. Na prática, essa estratégia se deu com a implementação e a regulamentação de um Sistema Único de Saúde, que passou a funcionar a partir da Lei Federal no 8080, de 19 de setembro de 1990 (BRASIL, 1990). No entanto, na mesma década, as forças políticas se modificaram e a estratégia foi deixada de lado, o que trouxe consequências na implementação do SUS: o conceito de saúde continuou a ser entendido pelos planejadores de políticas públicas como se as intervenções médicas fossem somente de ordem preventiva e curativa. O cenário só se modificou a partir de 1995, quando o Brasil efetivamente introduziu o ideário de Promoção da Saúde em seu território. Esse resumo do movimento de Promoção da Saúde integra um panorama histórico maior de 
lutas e de conferências mundiais que valem ser destacados, conforme será mostrado no tópico a seguir, ainda com Westphal (2007).

\subsubsection{Contexto histórico da Promoção da Saúde}

A introdução do ideário e dos princípios da Promoção da Saúde decorreu de um longo processo, que surgiu na Europa, no século XIX, em que se reconhecia que as condições de saúde estavam ligadas às condições de vida. Um exemplo a ser citado é o de que, em meados de 1840, a população da Inglaterra levantou lutas contra a degradação urbana na Europa, cujos efeitos desfiguraram as condições sociais e de saúde dos indivíduos.

Ainda que se observem tais iniciativas, até o princípio dos anos de 1970, a saúde concentrava-se em hospitais superespecialistas, cujo valor era a cura, e não a prevenção. Esse valor foi questionado em 1974, com o Relatório Lalonde, intitulado "Novas Perspectivas de Saúde dos Canadenses”, no qual se questionou a exclusividade da medicina na resolução dos problemas de saúde (LALONDE, 1974). O argumento era de que a saúde do indivíduo e a de uma comunidade dependem “das interações dos grupos sociais, das políticas adotadas pelo governo, [...] do ensino da medicina, da enfermagem, da educação, das intervenções sobre o meio ambiente” (WESTPHAL, 2007, p. 11).

Em complemento, na Conferência Internacional de Promoção da Saúde, no Cazaquistão (ex-URSS) em 1978, foi feita a Declaração de Alma-Ata, onde se deu a definição da promoção da saúde como sendo uma nova saúde pública. E em que se reconhecia a saúde como um direito a ser afirmado, não só com vistas à melhoria dos serviços de saúde, como também por um trabalho cooperativo com os outros setores da sociedade (SÍCOLI; NASCIMENTO, 2003, p. 106-108).

Já em 1984, no Congresso Canadense de Saúde Pública, foram definidos os princípios da Promoção da Saúde (SÍCOLI; NASCIMENTO, 2003, p. 107), que são:

1) Envolvimento da população como um todo;

2) Dirigida para a ação sobre os determinantes ou causalidade social, econômica, cultural, política e ambiental da saúde;

3) Combina métodos e abordagens diversos;

4) Objetiva a efetiva a participação social;

5) É uma atividade do campo social e da saúde, e não somente um serviço.

Dessa maneira, o conceito de nova saúde pública reforça a relevância da ação política, das condições ambientais e mudanças no estilo de vida, segundo Westphal (2007, p. 11), com 
o reconhecimento de que a saúde é um critério de governo no processo de tomada de decisões sobre o desenvolvimento econômico e social.

Já a relevância do papel das políticas públicas na resolução dos problemas de saúde entrou em pauta em 1988, na Conferência de Adelaide, na Austrália, perspectiva esta reforçada durante a conferência internacional da ECO92, realizada no Brasil em 1992. Nesta ocasião, ressaltou-se a importância de construir ambientes de apoio à Promoção da Saúde, bem como implementar políticas públicas na área ambiental, com o intuito, sobretudo, de respeitar a sustentabilidade ambiental no desenvolvimento dessas políticas.

Outro destaque foi a Conferência de Jacarta, que aconteceu na Indonésia, em 1998, em que foram definidas as cinco prioridades para a Promoção da Saúde até o século XXI:

1. Promover a responsabilidade social pela saúde;

2. Aumentar a capacidade da comunidade e o poder dos indivíduos para controlar as ações que pudessem interferir nos determinantes da saúde;

3. Expandir e consolidar alianças para a saúde;

4. Aumentar as investigações para o desenvolvimento da saúde;

5. Assegurar a infraestrutura para a promoção da saúde (WESTPHAL, 2007, p. 15).

No entanto, durante a V Conferência da Promoção da Saúde, ocorrida no México em 2000, assumiu-se que as prioridades acima mencionadas não foram cumpridas. E, durante a Sexta Conferência Global de Promoção da Saúde, de 2005, em Bangcoc, na Tailândia, dois pontos foram reconhecidos: grandes mudanças se deram com a revolução da tecnologia da informação; a universalização dos movimentos sociais fortalece a promoção da saúde e a melhoria da qualidade de vida (WESTPHAL, 2007, p. 16).

Nota-se que as conferências mundiais que aconteceram nos últimos anos reforçam a proposta de ampliar o campo de ação, cujos princípios foram mencionados pela primeira vez na Carta de Ottawa, na Conferência de 1986, que são: a equidade, a participação social, a intersetorialidade e a sustentabilidade. E, na proposta de ampliação do campo da saúde, a carta inclui os seguintes pontos, conforme aponta Westphal (2007, p. 17):

1) Estabelecimento de políticas públicas saudáveis;

2) Criação de ambientes de apoio à Promoção da Saúde - cidades, escolas, ambientes de trabalho, praças, parques ecológicos e outros;

3) Fortalecimento da ação comunitária;

4) Desenvolvimento de habilidades e atitudes;

5) Reorientação dos serviços de saúde no sentido de sua produção social. 
Mesmo com todos os princípios e uma agenda em que se começa a valorizar a Promoção da Saúde, Westphal (2007) questiona se o movimento tem estimulado o diálogo entre os diversos saberes, bem como se tem reconhecido e incluído todos os atores responsáveis por viabilizar as ações de atenção e promoção da saúde das populações. Tal reflexão leva a autora a considerar o termo qualidade de vida, cujo significado constitui-se em uma construção social, com marca da relatividade, visto que tem três referências: histórica, cultural, estratificações e classes sociais.

Além disso, ainda que a qualidade de vida seja ligada a fatores objetivos e subjetivos, ela considera ser possível definir que o termo contempla aspectos relacionados às "condições materiais de vida e à subjetividade nas relações dos homens entre si e com a natureza” (WESTPHAL, 2007, p. 19). Nesse sentido, é a qualidade de vida que possibilita que todos os grupos populacionais desenvolvam suas capacidades humanas básicas, cujo padrão globalmente adotado para mensurar esse qualitativo é o Índice de Desenvolvimento Humano (IDH), criado por Mahbub ul Haq, em colaboração com o economista indiano Amartya Sene ${ }^{8}$.

Os marcos históricos e teóricos da promoção da saúde, bem como as reflexões sobre a qualidade de vida, podem ser postos em prática após a implementação de políticas públicas para qualidade de vida, tema que será tratado no próximo tópico, com Fernandez e Mendes (2007).

\subsubsection{Políticas públicas e qualidade de vida}

A temática da Promoção da Saúde também é tratada por Fernandez e Mendes (2007). Para esses autores, a saúde se produz socialmente e é reflexo do modo e da qualidade de vida de uma população. Com isso, a promoção da saúde pressupõe o reconhecimento ético de responder às necessidades sociais no marco dos direitos universais fundamentais, já que o direito à saúde é expressão do direito fundamental à vida.

A Promoção da Saúde se expressa em duas dimensões: na intersetorialidade e na participação. Por intersetorialidade, os autores definem como “[...] convergência de esforços de diferentes setores governamentais e não governamentais para produzir políticas integrais e integradas que ofereçam respostas às necessidades geradas” (FERNANDEZ; MENDES, 2007, p. 29). E, no contexto da construção de agendas sociais, a participação consiste em

\footnotetext{
${ }^{8}$ Para mais informações, ver Anexos.
} 
potencializar as redes existentes, contribuir para formar novas redes sociais promotoras da qualidade de vida, e que operem em territórios políticos e sociais.

Tanto no âmbito da intersetorialidade quanto no da participação social, faz-se necessária a ação dos atores sociais para que estes se tornem protagonistas na definição das políticas públicas (FERNANDEZ; MENDES, 2007, p. 33). Isso se dá porque, por não serem exclusivas do aparelho estatal, as políticas públicas saudáveis possuem o desafio das negociações e lutas em variados cenários de uma sociedade desigual.

Outro ponto destacado pelos autores é o de que, na concepção da Promoção da Saúde, as políticas públicas saudáveis devem estar comprometidas com o desenvolvimento humano sustentável e com a sustentabilidade dessas políticas, no sentido de que os projetos, ações e políticas sejam permanentemente postos em pauta pelos gestores.

Um modelo de gestão proposto é o de investir na construção de uma participação social informada e solidária, com o desenvolvimento de uma “[...] sistemática de leitura do território e das necessidades locais ou inovar na busca de ações integradas” (FERNANDEZ; MENDES, 2007, p. 37). Uma gestão dessa natureza - diversa e plural que pode agregar mais crítica, qualidade e pertinência às ações e política. O que acarreta, por si só, a sustentabilidade das políticas públicas e a menor influência das disputas partidárias.

Por fim, os autores sinalizam dois desafios na implementação das políticas públicas: considerar a saúde sob a ótima do desenvolvimento da condição humana; e, do ponto de vista ético, tomar as funções públicas como um “compromisso de empreender ou consolidar avanços na área social, [...] dando destaque para a importância do debate acerca do imperativo ético da vida e de sua qualidade.” (FERNANDEZ; MENDES, 2007, p. 37).

Complementando os pensamentos de Fernandez e Mendes (2007), quem também articula a questão da participação social nas políticas públicas são Bógus e Westphal (2007). Contextualizando, com base no 'Movimento Cidades Saudáveis', as autoras reforçam a importância da participação social por uma cidade saudável, visto que integra um processo relacional que opera no campo da construção das identidades e promove a reflexão da ação social. Por participação social, entende-se a partilha do poder decisório, superando conflitos de interesse, por meio da negociação. Tomamos o conceito de cidades saudáveis no contexto de agendas urbanas de desenvolvimento social, e cujo objetivo, segundo Bógus e Westphal (2007, p. 62) é

operacionalizar uma nova forma de gestão municipal, em que as autoridades políticas e civis, as instituições públicas e privadas, os empresários, os trabalhadores e toda a sociedade civil dedicam esforços constantes para melhorar as condições de vida, trabalho e cultura da população, estabelecem uma relação harmoniosa com o meio ambiente, além de fortalecerem a 
participação comunitária para melhorar a convivência, desenvolver a solidariedade, a cogestão e a democracia.

Embora o conceito se articule com a Promoção da Saúde, a presente pesquisa não pretende aprofundar as questões que constam do movimento Cidades Saudáveis. A participação social está diretamente relacionada à atuação dos movimentos sociais, isto é, aos novos sujeitos políticos, que possuem uma forma específica de mobilização social, com espaço próprio e características singulares, para Bógus e Westphal (2007). No que concerne aos movimentos de saúde, estes se enquadram no perfil dos que se mobilizam não exclusivamente pela carência de equipamentos sociais, mas, também, por condições que afetam suas vidas.

Nesse sentido, os movimentos de saúde querem ampliar o canal de acesso ao Estado, tendo em vista a possibilidade de superar a visão de que a atividade política é dissociada do cotidiano dos indivíduos comuns (BÓGUS; WESTPHAL, 2007, p. 70). As autoras reforçam que a participação da sociedade civil não pretende acabar com o papel do Estado, mas, sim, “[..] reivindicar e lutar para que este cumpra o seu papel de propiciar, universalmente, educação, saúde e demais serviços sociais com qualidade” (BÓGUS; WESTPHAL, 2007, p. 79). Em suma a questão da participação objetiva promover a autonomia do cidadão para participar da sociedade sem depender diretamente do Estado.

Com base nos contextos apontados, é possível depreender que a Promoção da Saúde abarca as questões da participação social e da intersetorialidade, sendo a importância do movimento já documentada e discutida em conferências e movimentos sociais. Além disso, tornou-se parte relevante da agenda de construção de políticas públicas de saúde.

Já no tópico a seguir, Minayo (1992) tratará de outra temática relacionada: a da relação entre saúde, doença e sociedade, articulando a saúde do indivíduo com a sociedade em que vive.

\subsection{Saúde coletiva: saúde, sociedade}

Quem também aborda e concorda com os princípios da saúde como um campo interconectado com outras áreas é Minayo (1992), que em sua obra salienta que o campo da saúde não se separa das outras instâncias da realidade social, visto que possui uma abrangência multidisciplinar e estratégica. Além disso, a relação saúde/doença envolve fatores endógenos e exógenos, relação que expõe construção de uma realidade social. E, para se compreender essa realidade, “[...] é preciso examiná-la, baseando-se nos substratos econômico, político e cultura no qual vivemos” (MINAYO, 1992, p. 179). 
O reforço de que a saúde não é um campo separado das outras instâncias da realidade constitui-se em princípio que retoma o termo Saúde Pública. O significado do termo consagra uma intervenção do Estado na direção do social, uma área mais ampla e complexa do que a visão definida pelas práticas sanitárias oficiais.

Essa visão começou a se fortalecer na América Latina a partir da década de 1970, período em que, na região, mudou-se o foco de conceito de Saúde Pública e passou-se a adotar o conceito de Saúde Coletiva. O que passa a ideia de “direitos, situação histórica, comprometimento de condições de vida social e uma crítica ao indivíduo como responsável único por sua saúde/doença” (MINAYO, 1992, p. 79). Quando se parte da ideia de saúde coletiva, o papel do Estado torna-se essencial, como um instrumento que reflete as contradições e as próprias lutas de classes geradas pela segregação social, conforme aponta Minayo (1992). É o Estado quem regula as contradições sociais e atenua os efeitos das desigualdades, conforme a seleção dos recursos públicos destinados aos meios de consumo coletivo.

O novo pensamento deriva da concepção de Medicina Social, que, desde o século XX, projetou que "a doença, a saúde e a morte não se reduziam a uma evidência 'orgânica', 'natural', mas estavam intimamente relacionadas com as características de cada sociedade” (MINAYO, 1992, p. 175). A Medicina Social também preconiza que a doença é uma realidade construída e o doente é um personagem social.

Deste modo, o discurso sobre saúde / doença integra uma construção social e, por isso, também possui particularidades conforme a sociedade, o que corresponde "[...] à coerência ou às contradições de sua visão de mundo e de sua organização social” (MINAYO, 1992, p. 176). A autora pontua os seguintes fatores - endógenos e exógenos - que levam à concepção de saúde/doença:

- Médico/clínico: fatores endógenos "pensados através dos processos biológicos";

- Senso comum: o indivíduo é responsável por sua doença, causada por "questões hereditárias, castigo divino ou pecado individual”;

- Sociedade: uma causa exógena, que corresponde ao "desequilíbrio entre as relações sociais de determinado grupo e dele com o seu meio” (MINAYO, 1992, p. 178, grifos do autor).

Quanto ao senso comum, é frequente a atribuição da responsabilidade individual de um problema que, muitas vezes, é social - relacionado a uma sociedade agressiva, opressiva e que promove um estilo de vida pouco saudável. Contudo, independentemente da explicação e dos fatores, “é o indivíduo que adoece e morre. No entanto, a atribuição de sentidos das causas endógenas é também socialmente construída” (MINAYO, 1992, p. 178). 
Por sua vez, o saber médico e clínico é dado pela autora como contraditório, pois este profissional lida, conforme assevera Minayo (1992), com um esquema corporativo, marcado por diversos interesses e discursos, que geram concepções contraditórias acerca do corpo, sobre a saúde / doença, sobre a vida e a morte. E a medicina moderna não só ampliou essa contradição, como reforçou a autoridade do ato médico, atribuindo-lhe monopólio até mesmo em campos antes abandonados de sua jurisdição, “[...] como a criação dos recém-nascidos ou a alimentação” (MINAYO, 1992, p. 182).

Outro ponto sobre o saber médico é a existência de um reforço ao contorno biológico e individual do doente, bem como a explicação do fenômeno saúde/doença baseando-se somente no "bom funcionamento dos órgãos” e atribuindo a responsabilidade da saúde para o indivíduo. O sistema dominante trata "as doenças provocadas pelas condições de vida e de trabalho [...] como uma questão individual ou inespecificamente como 'males da vida moderna”" (MINAYO, 1992, p. 190, grifo do autor).

Já as doenças relacionadas às condições precárias do ser humano, apenas há pontos em comum um tanto sutis, aponta Minayo (1992), e como algo que deve mobilizar diversos setores da saúde, pois não atinge todos os grupos sociais. Com isso, tais doenças são “[...] socialmente 'desconstruídas', despidas de seu caráter social e transformadas em 'culpa', 'descuido', ‘ignorância popular’” (MINAYO, 1992, p. 191). Esse ponto de vista das representações dominantes é o que viabiliza o deslocamento do significado de saúde como um campo de ação individual. Uma representação individualizada adota a premissa de que saúde consiste na existência de uma sociedade equilibrada, e permitida em ser controlada pelas vontades pessoais.

Em contraposição a esse discurso, a autora propõe que se estabeleça uma relação de saúde como uma “[...] questão vital de atribuição individual e coletiva e que ultrapasse os aspectos biofisiológicos” (MINAYO, 1992, p. 191). Nesse sentido, a questão da saúde sai do campo estritamente médico e vai para a arena do conjunto das reivindicações por direitos sociais, nos explica Minayo (1992, p. 192). A autora considera importante politizar a saúde, por meio de uma mudança no paradigma e de uma redefinição “do processo que leve em conta todos os aspectos que concernem ao corpo, à mente e ao meio ambiente” (MINAYO, 1992, p. 193). Evidencia-se, então, uma representação social da saúde/doença com base não somente dos “aspectos universalmente observáveis, [...] mas a outros que são peculiares a cada sociedade” (MINAYO, 1992, p. 193).

Em suma, a autora considera importante reorientar a existência da conexão entre o indivíduo, a sociedade e seu ecossistema, o que amplia o entendimento desta relação tríade 
com a saúde/doença. Além disso, infere que as condições de saúde são marcadas por contradições de uma sociedade desigual e com relações sociais assinaladas por essas diferenciações de classes. Reconhecer tal complexidade dos fenômenos é um “[...] requisito indispensável para pensá-los cientificamente: não existe nenhuma simplicidade nos microfenômenos, visto que o fato aparentemente mais simples é um complexo de relações” (MINAYO, 1992, p. 251). Esse intrincado de relações também pode ser encontrado na conexão entre saúde, comunicação e cidadania, conforme é explicitado no próximo tópico, com Kucinski (2000).

\subsection{Comunicação e saúde na promoção da cidadania}

No artigo “Jornalismo, saúde e cidadania”, (2000) mostra que a relação da saúde com a comunicação é um importante instrumento na ampliação dos direitos de cidadania. Isso porque tais relações representam matrizes para se estabelecer um novo padrão de conexões sociais entre agentes de saúde e cidadãos, "baseada na interlocução, participação e corresponsabilidade nas decisões de saúde” (KUCINSKI, 2000, p. 183). O autor parte do pressuposto de que a saúde é um direito de todos e um dever do Estado, dentro do campo da comunicação, e imagina que a cobertura de saúde seja considerada um jornalismo de serviço e que a saúde, assim como as políticas públicas e terapias de saúde, adquirem um valor político na esfera da cidadania, nos explica Kucinski (2000, p. 183)

Dois pontos devem ser considerados para o comunicador que trata do tema: a necessidade de uma visão holística do processo saúde-doença; e a ciência de que existe um relativismo na prática médica dominante. Contudo, o discurso que predomina na mídia é o de saúde combativa, que combate os sintomas, mas não as causas. Nessa linha de raciocínio, não se investigam as causas de um problema que, de acordo com o autor, “[...] seriam a consequência da má qualidade ambiental ou de vida” (KUCINSKI, 2000, p. 183).

Quanto à má qualidade de vida, uma das soluções colocadas pelo autor é a inserção de políticas públicas em saúde. Porém, o comunicador deve manter-se crítico em relação a tais políticas, “e perceber o caráter utópico, e, em alguns casos, o caráter de fuga das campanhas públicas, quando tentam erradicar uma endemia sem alterar as condições socioeconômicas, que são a sua causa principal” (KUCINSKI, 2000, p. 183).

O autor ainda ressalta que as campanhas comunicacionais em saúde são insatisfatórias por diversos motivos, como "nossa falta de conhecimento ou nossos equívocos no 
entendimento da relação entre mensagem e receptor, no papel da interatividade, na capacidade de a informação mudar hábitos, ideias ou estilos de vida, no papel das linguagens na comunicação” (KUCINSKI, 2000, p. 185).

Além do desconhecimento do processo de transmissão e recepção da mensagem por parte de quem produz a informação, outro aspecto que atrapalha na comunicação para a saúde é a demarcação ética da qual trata o jornalismo. O comunicador deve ter senso crítico ao se envolver em campanhas de políticas públicas em saúde, para não “[...] trocar a lógica analítica e explicativa do bom jornalismo pela lógica da persuasão” (KUCINSKI, 2000, p. 185). O autor aborda, também, como dilema ético a questão de que as ações apresentadas em campanhas para a saúde são frequentemente mostradas como as únicas possíveis.

Contudo, todas as campanhas não são neutras, pois envolvem opções, que, sejam do Estado, sejam do veículo midiático, envolvem um contexto de opções políticas, determinações de classes ou "estamentos", bem como os interesses financeiros ou geopolíticos.

Em uma afirmação polêmica, Kucinski (2000, p. 185) considera que campanhas massivas, como as de vacinação, constituem-se em paliativos para não precisar mexer na estrutura econômica e social de doenças que são decorrentes de uma sociedade desigual e um habitat sujo. A afirmação permite a inferência de que as campanhas de saúde são, de forma geral, uma maneira de mascarar uma questão mais abrangente, que envolve opções políticas de não se tratar o cerne do problema, que é a desigualdade social.

\subsection{Modelo de comunicação para políticas públicas}

Concordando com Kucinski (2000) sobre a necessidade de inserção de políticas públicas de saúde para a sociedade, Araújo (2004, p. 167) propõe um modelo comunicacional que represente uma prática comunicativa como um processo de intervenção social que concretize as políticas públicas. Para a autora, na sociedade contemporânea, a comunicação opera como um mercado, “onde os sentidos sociais - bens simbólicos - são produzidos,

circulam e são consumidos”. E os indivíduos que vivem nesse mercado negociam sua participação, com o objetivo de ampliar sua influência. Contudo, em uma sociedade desigual, tais interesses são motivos de conflitos, já que “[...] os interesses não são harmônicos: em um mercado simbólico, a luta se dá por posições de poder discursivo” (ARAÚJO, 2004, p. 167).

A questão é complementada também por Araújo e Cardoso (2007), cuja obra as autoras intitulam o campo da Comunicação e Saúde como C\&S, e que "trata da comunicação 
nos processos de elaboração, implantação e gestão e políticas públicas nos domínios onde se requer uma ação pública, incluindo aí o da saúde.” (ARAÚJO; CARDOSO, 2007, p. 20-22).

Para as autoras, as políticas públicas só existem quando saem do papel, circulam e são apropriadas pela população a que se destinam - processo em que a comunicação é indispensável. No entanto, sabe-se que as políticas públicas são decididas em um processo de disputa de pontos de vista, e, em um embate de ideias, quando um grupo ou alguém possuir um ponto de vista mais aceito como verdade, terá chances maiores de direcionar o investimento público no setor, isto é, influenciar as políticas públicas.

Atualmente, ainda que o Brasil reconheça a importância da comunicação para as políticas públicas de saúde, essa relação é recente, e envolve determinados marcos históricos. Para contextualizar a formalização do campo da C\&S, cabe elencar quais foram os processos históricos em âmbito nacional, conforme será mostrado no próximo tópico.

\subsubsection{Comunicação e políticas públicas para a saúde: processos históricos}

No Brasil, os processos históricos, que culminaram no estabelecimento da relação entre comunicação e saúde, se deram a partir de 1920, quando o Departamento Nacional da Saúde Pública (DNPS) “[...] incluiu a propaganda e a educação sanitária como estratégia para fazer face às questões de saúde, principalmente as epidemias e a adoção de medidas higiênicas” (ARAÚJO; CARDOSO, 2007, p. 24). À época, o componente educativo ganhou relevância porque se percebeu que os indivíduos “[...] precisariam corrigir seus hábitos tidos como nefastos à saúde” (ARAÚJO; CARDOSO, 2007, p. 24). Nesse contexto interpretativo, a educação e a comunicação constituíam-se no binômio que possibilitaria o sucesso das políticas públicas em saúde, que se estendeu pelo século $\mathrm{XX}$ até os dias atuais.

A articulação do papel da educação e da comunicação na saúde se consolidou nos anos de 1940, com as políticas públicas criadas por Vargas, como o serviço Nacional de Educação Sanitária (SNES) e o Serviço Especial de Saúde Pública (SESP): ambos produziam materiais educativos e informativos. Já a formação em C\&S - como um conjunto de elementos articulados e reconhecidos - é recente, e se dá a partir da década de 1990 por Araújo e Cardoso (2007).

O crescimento do campo da saúde, inserindo-se como espaço articulado aos movimentos sociais ligados à área, pode ser considerado efetivo desde a Conferência Nacional de Saúde (CNS). Esta teve início durante o governo Vargas e, a partir da década de 1980, passou a integrar representações de vários segmentos sociais. Tal quais os conselhos de 
saúde, as conferências constituem-se nos principais espaços de participação e controle social no setor.

Foi em 1986, durante a VIII CNS, que se tornou pública a emergência da comunicação, a informação e a educação como elementos fundamentais ao direito à saúde. Já a consolidação da fórmula da Informação, Educação e Comunicação (IEC) se deu em 2000, na ocasião da XI CNS. E, em 2003, na XII CNS, foram incluídas a comunicação e a informação entre os seus dez eixos temáticos, bem como se recomendou a realização da I Conferência Nacional de Informação, Comunicação e Educação Popular em Saúde.

Araújo e Cardoso (2007) destacam que, embora a valorização da relação entre C\&S seja positiva, devem-se distinguir os termos informação e comunicação. A informação aprofunda

os fundamentos e métodos da produção dos dados e sua conversão em informação e a comunicação [...] deu mais atenção aos procedimentos pelos quais a informação pode ser tratada, circular e ser transformada em saberes pelas pessoas e instituições.” (ARAÚJO; CARDOSO, 2007, p. 31, grifo nosso).

Ainda que se tenha essa distinção, o que se verifica - por razões de ordem teórica e política é “o uso do termo 'informação' de forma substitutiva ao termo 'comunicação”” (ARAÚJO; CARDOSO, 2007, p. 31). Tal apropriação pode prejudicar a compreensão dos processos sociais implícitos e implicados no conceito de comunicação, que envolvem ações históricas, políticas e econômicas das relações sociais, bem como dificulta a percepção destes interesses em disputa. As autoras reforçam a importância de se compreender os campos da comunicação, saúde e educação, de maneira que se incorporem às novas dimensões que se apresentam (tecnológicas, discursivas e políticas). E retomem as matrizes comuns entre os três campos - sempre à luz dos princípios do SUS - cujas diretrizes se alinham com o pensamento das autoras, conforme será mostrado no tópico a seguir.

\subsubsection{C\&S: relações de poder e SUS como princípio norteador}

O panorama histórico da área permite inferir que, até os primeiros anos do século XX, o modelo médico-sanitário remanejava a área da saúde pública do meio ambiente para o indivíduo, isto é, possuía uma visão individualizada dos determinantes de saúde. Nesta linha de raciocínio, é somente em consequência da mudança de comportamento e de hábitos que o indivíduo sai da condição de doença. No entanto, o modelo ignora os determinantes sociais 
das doenças, bem como confia à educação "a superação do atraso e a instalação de condições mais propícias ao progresso” (ARAÚJO; CARDOSO, 2007, p. 41).

Tal visão sanitarista advém do pensamento norte-americano que trata do binômio ignorância / maus hábitos como vala comum, à qual se destina qualquer resistência ao saber cientificamente orientado. A resistência do saber científico passou a receber o status de doença - a doença da ignorância - e, mais recentemente, da desinformação (ARAÚJO; CARDOSO, 2007, p. 42). E foi essa visão que passou a associar a educação e a comunicação como elementos essenciais na implantação de políticas públicas de saúde.

Um dos modelos de comunicação que reforçam o pensamento anterior é o modelo emissor, criado, em 1948, por Claude Shannon e Warren Weaver. Embora superado, o modelo ainda contribui para que educadores, comunicadores, planejadores e gestores da saúde acreditem que “a prática comunicativa se limita à transferência de informações a uma população que nada sabe de relevante sobre os assuntos que dizem respeito à sua saúde e sua vida” (ARAÚJO; CARDOSO, 2007, p. 46).

Para as autoras, esse modo de pensar é bastante problemático porque produz uma prática comunicativa sem diálogo e sem escuta, "que atribui o direito de voz e expressão apenas ao emissor, [...] silenciando a maioria” (ARAÚJO; CARDOSO, 2007, p. 47). Elas acreditam que uma parte considerável dos materiais informativos e educativos trata a população como carente ou ignorante e que, ainda, desconsideram a diversidade, a diferença e as vozes sociais que estão presentes. Ressalta-se também que essa linearidade de modelo dificulta a compreensão da natureza em rede dos processos comunicacionais, conforme destacam Araújo e Cardoso (2007).

Outro modelo comunicacional exposto pelas autoras é o da teoria do Two Step Flow, de Katz e Lazarsfeld, criado em 1955 (KATZ; LAZARSFELD, 1955). Nessa teoria, há um novo componente na relação emissor/receptor, com a inserção do mediador. Com esse elemento, o modelo trouxe a aposta na existência de “[...] instâncias intermediárias entre a fonte e o destino das mensagens” (ARAÚJO; CARDOSO, 2007, p. 54), que exerciam influência sobre o modo como os receptores decodificavam essas mensagens. O Two Step Flow possibilitou que, atualmente, se reconhecesse a figura do mediador na rede de comunicação que move as ações de saúde.

Ainda que se tenham modelos diversos em mente, no que concerne às práticas de saúde pública, mantinha-se o predomínio da visão sanitarista higienista, que tenta ajustar o comportamento “desviante” ao desejado. Além de tratar o conhecimento popular como superstição, usava a comunicação como principal arma de luta. Trazendo um contraponto a 
essa visão, de 1980 para os dias atuais, autores latino-americanos levantaram novos paradigmas das teorias da comunicação, com as teorias das mediações, “[...] em que o centro da cena teórica está na cultura e no cotidiano” (ARAÚJO; CARDOSO, 2007, p. 56). Outros estudos também se aprofundaram no entendimento dos grupos sociais e seus contextos, como os de recepção, mas o fator determinante na mudança de paradigma para as teorias da comunicação foi o conceito de polifonia, desenvolvido por Bakhtin, na década de 1920. Na polifonia, em cada fala, texto ou enunciado há uma variedade de vozes, sendo que a maioria não é detectada pelo locutor.

Nessa linha de raciocínio, as vozes correspondem a interesses diversos dentro da ordem social, o que faz com que a linguagem, segundo as autoras Araújo e Cardoso (2007), seja uma arena de embates sociais, na qual são propostas, negociadas e ratificadas ou recusadas as relações de poder. Bakhtin propõe que, para lidar com esses embates, é necessária a aplicação do dialogismo, conceito que propõe a visão da linguagem como um espaço de lutas e negociações, conforme destacam Araújo e Cardoso (2007, p. 57).

Para as autoras, vale a adoção do dialogismo como uma ferramenta de abordagem da comunicação para a saúde, pois ambas partem do pressuposto de que "nunca começamos do zero: os outros já têm um cabedal de informações e saberes que se articularão aos nossos” (ARAÚJO; CARDOSO, 2007, p. 58). Assim, não se tem a pretensão de levantar modelos que transferem mensagens a receptores desprovidos de referências: pelo contrário, o receptor é um interlocutor e um co-produtor de sentidos.

Outro pressuposto do campo da C\&S delimitado é o de que o direito à comunicação é inseparável do direito à saúde. Além disso, a comunicação só se dá plenamente se “[...] concebida e aplicada como redistribuição do poder de as pessoas se expressarem e serem levadas em consideração” (ARAÚJO; CARDOSO, 2007, p. 60). No campo da saúde, a comunicação é indissociável à noção de direito, dirigida a cidadãos, e objetiva “o aperfeiçoamento de um sistema público de saúde em todas as suas dimensões e a participação efetiva das pessoas na construção dessa possibilidade” (ARAÚJO; CARDOSO, 2007, p. 61).

Araújo e Cardoso (2007) concluem que a comunicação para a saúde objetiva não só uma estratégia e uma divulgação, mas, sim, o "estabelecimento de um debate público sobre temas de interesse e garantir às pessoas informações suficientes para a ampliação de sua participação cidadã nas políticas de saúde” (ARAÚJO; CARDOSO, 2007, p. 61). Esse objetivo coincide com os princípios do SUS, que são: universalidade, equidade e integralidade - juntamente com seus princípios organizativos, caracterizados pela 
descentralização, hierarquização e participação. Na prática, as autoras aplicam cada princípio dentro do contexto da C\&S, conforme será mostrado nos parágrafos seguintes.

O primeiro princípio do SUS, o da universalidade, dentro do contexto da C\&S, se dá pelo discurso da democratização da informação, que, na saúde, “[...] se expressa na reivindicação pelo acesso ampliado e facilitado às informações necessárias para o exercício do controle social” (ARAÚJO; CARDOSO, 2007, p. 62). Nesse sentido, é necessário avançar na compreensão teórica da comunicação, realizando um contraponto a uma "comunicação linear, bipolar e unidirecional” para uma "comunicação em rede, um tecido formado por muitos fios” (ARAÚJO; CARDOSO, 2007, p. 63).

Já o princípio da equidade se dá com a comunicação respeitando as diferenças, isto é, partindo da premissa de uma sociedade desigual, o que aponta para a adoção de estratégias redistributivas. Araújo e Cardoso (2007, p. 65) reforçam que a capacidade de comunicar está diretamente ligada à capacidade de contextualizar, visto que se não nos apercebemos dos contextos em que a comunicação se realiza produziremos uma comunicação autista. Um parâmetro para a diretriz da equidade é a possibilidade de apropriação, pois a “circulação é o espaço mais definido do exercício do poder simbólico, portanto também lugar da luta por hegemonia e da exclusão social” (ARAÚJO; CARDOSO, 2007, p. 66). É no âmbito da circulação que as vozes são amplificadas ou silenciadas, que a desigualdade se manifesta mais fortemente.

Uma das teorias centrais da C\&S pontuadas pelas autoras é a de que, na comunicação, existem posições mais centrais e outras mais periféricas, “[...] que correspondem ao poder de produzir e fazer circular sua percepção do mundo” (ARAÚJO; CARDOSO, 2007, p. 67). Dentro dessas posições, existem os lugares de interlocução, ou seja, o lugar em que cada interlocutor ocupa no momento da comunicação, e que são determinados pelos contextos como o histórico, político, econômico, geográfico e institucional. Em uma sociedade com diferenças sociais, o desafio é favorecer uma maior mobilidade de centro e periferia.

Por fim, o último atributo do SUS, o da integralidade, aplicado à comunicação, significa a prática de escuta e reconhecimento do outro, servindo-se de um "espaço de conversa e troca [...] e recusa ao fechamento dos sentidos e ao privilegiamento das falas autorizadas” (ARAÚJO; CARDOSO, 2007, p. 73). Uma dimensão importante da integralidade é a oposição à fragmentação e desarticulação entre os níveis de atenção bem como a oposição à especialização, que começa no processo de formação.

Embora as autoras compactuem com os princípios do SUS e acreditem que tais princípios devam ser aplicados ao campo da C\&S, elas igualmente reconhecem que, no 
contexto de uma sociedade desigual, “[...] nenhum mercado, inclusive o simbólico, pode ser visto como espaço de interação de iguais” (ARAÚJO; CARDOSO, 2007, p. 74). Partindo do pressuposto de desigualdade, “a negociação se reveste (...) do caráter de luta por melhores posições” (ARAÚJO; CARDOSO, 2007, p. 75). Isso porque, de um modo geral, quem está na posição mais central quer manter-se ali, enquanto que os situados mais à periferia desenvolvem seus próprios modos de mudar o cenário.

Em um mercado simbólico, quem detêm a competência linguística exerce também uma distinção social perante o outro. Contudo, essa competência é exercida desigualmente, “monopolizada por alguns, enquanto outros [...] 'são despossuídos em graus variados”” (ARAÚJO, 2004, p. 169, grifo do autor). Isso se dá porque o espaço comunicativo é préconstruído, ou seja, operado por um grupo social determinado, regido por regras determinadas, que estabelecem, entre outras coisas, quem pode falar e o que se pode falar, para Araújo (2004, p. 169).

Araújo (2004, p. 172) ressalta que a desigualdade dos discursos se reflete em duas instâncias: nas condições de produção e de circulação. Nas condições de produção, a desigualdade aparece de forma mais evidente, pois é determinada, por exemplo, por quem detém o controle dos canais de comunicação. Mas, é na circulação de informação que as desigualdades sociais aparecem de maneira mais evidente: em meio a tantos discursos, quem consegue ser ouvido é quem detém o poder de comunicação. Isso porque a circulação é a instância que confere existência aos produtos simbólicos, “que os tira do âmbito privado e os torna de fato públicos” (ARAÚJO; CARDOSO, 2007, p. 75). Outro ponto que reflete a assimetria do poder discursivo são as condições de consumo e a apropriação da informação, posto que, para alguns setores específicos, como os da saúde coletiva ou dos que lutam pela democratização da informação, as possibilidades de acesso a outras fontes de informação são dificultosas.

Retomando os princípios organizativos do SUS, as autoras reforçam que a descentralização, no contexto da comunicação para a saúde, representa a desconcentração do poder. Contudo, sabe-se que a comunicação segue na trajetória de concentrar o poder de fala nas instituições, centralização que gera consequências, como voltar os recursos para o modelo “campanhista” de saúde e de comunicação, produzindo as informações à população de forma centralizada.

Para mudar o quadro, Araújo (2004, p. 173) propõe um modelo de comunicação “reticular, multipolar, multidirecional, desenvolvido para a compreensão da prática comunicativa no campo das políticas públicas” (Figura 1). O modelo em rede representa os 
espaços sociais que, como tal, "são arena dos embates sociais e lutas políticas” e a articulação de seus campos permite "tanto a representação quanto a transformação das relações de poder” (ARAÚJO; CARDOSO, 2007, p. 80).

O modelo promove uma fluidez dos interlocutores, estejam no centro ou na periferia, para que favoreçam o “equilíbrio de forças”. Essa descentralização é relevante no contexto da comunicação, que está no cerne das relações de poder e, portanto, concentrar comunicação significa concentrar poder (ARAÚJO; CARDOSO, 2007, p. 77).

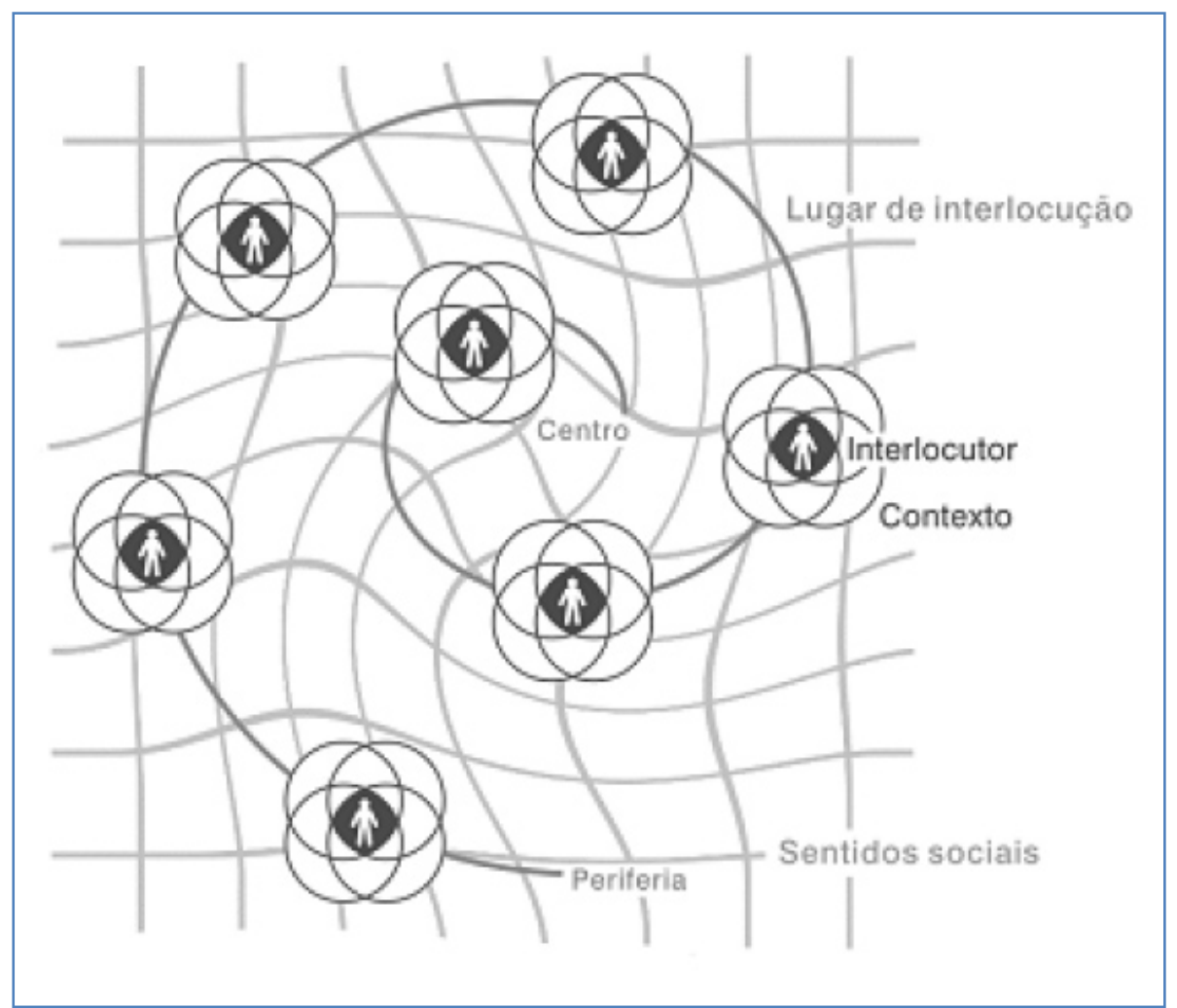

Figura 1: Representação do modelo de comunicação completo, proposto por Araújo (2004, p. 173)

Dessa maneira, o modelo proposto por Araújo (2004) visa ampliar os discursos, baseando-se na premissa que a sociedade é desigual, o que, consequentemente, demonstra que as oportunidades de discurso no mercado simbólico também não são as mesmas. Nesse sentido, um modelo de comunicação multidirecional proporcionaria uma democratização das vozes que compõem o campo das políticas públicas. Assim, não só o saber técnico entraria nas pautas, mas possibilitaria uma ampliação de vozes dos setores periféricos, os quais igualmente mostrariam seus sentidos e significados.

Com a descentralização, favorece-se o surgimento de canais locais de expressão e a circulação de mensagens, distribuem-se os recursos de maneira mais igual, bem como os 
contextos e os atores da sociedade são contemplados de maneira mais efetiva (ARAÚJO; CARDOSO, 2007). Numa perspectiva que contemple a descentralização, a equidade e a universalidade, a comunicação pede que sejam desenvolvidos mecanismos redistributivos, o que não significa falar de igualdade de competências, "mas de criar condições para que a polifonia social seja ouvida e de fato considerada” (ARAÚJO; CARDOSO, 2007, p. 82).

Entre os mecanismos redistributivos, pode-se citar a participação ativa da sociedade em vários níveis, sobretudo nos conselhos gestores, que são organizados "no planejamento, na implantação e na fiscalização de políticas públicas de saúde” (ARAÚJO; CARDOSO, 2007, p. 82). Tais medidas encontram os principais desafios e dificuldade no cotidiano, tendo a comunicação um importante papel de mediador, podendo facilitar ou dificultar a participação.

A comunicação se torna dificultosa à participação se a única prática for a de dar voz aos profissionais da saúde, que passam à população seus conhecimentos e saberes, sem dar voz à sabedoria popular ou oferecer interlocução. Ou, ainda, apresentarem-se os problemas de saúde como consequência de um comportamento individual, ocultando as causas sociais, econômicas e políticas. Também será dificultada se as questões de saúde forem tomadas como problemas pontuais, em que se fazem campanhas comunicacionais em determinadas situações específicas, deslocando grande parte das verbas públicas para elas e deixando de lado outras necessidades.

Já a comunicação será facilitada se a estratégia principal for a de promover espaços, processos e práticas que disseminem as vozes periféricas, tanto das comunidades discursivas, como dos trabalhadores da saúde ou da população, de forma que ampliem suas vozes, interesses e pontos de vista. Em complemento, a interlocução se dará se fornecer, a essa população, conhecimentos sobre seus direitos e outras informações que facilitem o acesso às instituições e serviços de saúde, favorecendo a possibilidade de ela se apropriar e potencializar as iniciativas surgidas nas políticas públicas.

Para compreender os atuais desafios do campo da C\&S, no próximo tópico são demonstrados quais são as estratégias já adotadas na área e o que poderia ser feito para efetivar as políticas públicas em saúde, visando os princípios do SUS. 


\subsubsection{Comunicação e Saúde: emergência de novos sentidos e usos sociais}

Para as autoras (ARAÚJO; CARDOSO, 2007, p. 89), as atuais práticas comunicativas têm as seguintes demandas:

1) Ampliação do acesso às informações governamentais: a demanda mais antiga do SUS, que se constitui em estratégia de circulação e democratização do acesso à informação, visto que transforma um bem privado em bem público.

2) Ampliação do direito de falar e de ser ouvido: representa a emergência de novos temas, novos projetos e necessidades. Essa demanda traz a ideia de que as políticas de comunicação, assim como as demais políticas públicas, são públicas não só pelos objetivos que perseguem, mas por considerar e negociar com a pluralidade de interesses na sociedade.

3) Visibilidade pública para seus temas, interesses e proposições: tal proposição entra diretamente na instância midiática, pois os meios de comunicação são a principal instância que propicia a existência pública dos temas e interesses sociais. Nessa demanda, duas estratégias são colocadas: reivindicar espaços dentro da chamada grande mídia, apresentando sua maneira de ver os acontecimentos da saúde; criar mídias próprias, com objetivo local e voltado para necessidades mais restritas. Segundo as autoras, é importante a criação de mídias próprias porque o que se observa nos sentidos dominantes da mídia em saúde é a associação da saúde ao consumo de bens, serviços e tecnologias.

Araújo e Cardoso (2007, p. 92) acreditam que as duas estratégias não devem ser desprezadas, “[...] seja pelo que trazem de possibilidades de avanço ou de retrocesso ao direito a melhores condições de vida e saúde”. As autoras ainda reforçam que o acesso às tecnologias de comunicação interessa também à saúde, sendo um exercício da intersetorialidade. Tal necessidade constitui-se nas novas demandas que clamam por descentralização da comunicação, com maiores condições de equidade, integralidade e participação. Em contrapartida, essas novas exigências convivem com interesses de grupos hegemônicos “que apostam na concentração e no controle do direito de fala” (ARAÚJO; CARDOSO, 2007, p. 95).

Há a necessidade de reforçar a existência do embate de interesses, porque, embora o campo da saúde seja "um destes universos eivados de idealismos e boas intenções, não podemos operar com uma visão ingênua da conduta desinteressada dos 'jogadores'” (ARAÚJO; CARDOSO, 2007, p. 96). E as regras do jogo, que são dadas por quem está localizado nos núcleos centrais, são apresentadas como naturais e, se não forem questionadas, "serão o principal esteio da manutenção da ordem dominante".

As autoras reiteram que os membros que estão na periferia do discurso, e que visam diminuir as desigualdades de direitos e possibilidades, ainda assim estão em luta desigual 
com quem está no núcleo, visto que "se apoia na posse desigual das várias espécies de capital, inclusive o simbólico” (ARAÚJO; CARDOSO, 2007, p. 97). Para completar, Araújo e Cardoso (2007) argumentam que o Estado não tem clientes: sua relação é com cidadãos. Esse posicionamento reforça a compreensão de que o cliente tem direitos de consumidor, enquanto que o cidadão tem direitos de cidadania, tem direito à saúde.

Assim, a relação entre mídia e saúde pode ser avaliada nos dizeres de Araújo e Cardoso (2007, p. 99) como intensa e multifacetada: há um lado conflituoso dos discursos midiáticos que, "na opinião de muitos", antagonizam com os das instituições de saúde pública. Por outro lado, esses espaços midiáticos mostram-se como único espaço de comunicação rápido e abrangente, que possibilitam a circulação das mensagens produzidas pela saúde. A grande mídia também se coloca como um espaço de embates pelo poder simbólico e de estratégias que se originam e se desdobram em outros espaços.

As autoras também acreditam que o modelo dominante de C\&S é uma natureza “[...] transferencial e centralizadora, que, sob uma roupagem moderna e tecnologizada, continua seu percurso hegemônico" (ARAÚJO; CARDOSO, 2007, p. 100). Soma-se ao fato de que a mídia “toma leituras da realidade”, bem como articula suas lógicas e as naturaliza como verdades, mascarando a polifonia e a heterogeneidade atrás de uma aparência homogeneizada. Isso porque, de acordo com as afirmações das autoras ao longo de toda a obra, a mídia é, por excelência, espaço de embate das vozes sociais, que correspondem a interesses distintos.

Outra conclusão é a de que a mídia integra um sistema sociopolítico, cuja característica é a desigualdade, o que, por consequência, gera os embates e a desigualdade de vozes para atender os interesses em jogo. Nesse sentido, as vozes periféricas aparecem na mídia, porém, enquadradas em determinados critérios de produção de sentido, e “[...] despidas da carga ideológica que as anima e confere poder de mudança” (ARAÚJO; CARDOSO, 2007, p. 101).

Todas essas questões recaem novamente sobre a concentração dos meios de comunicação, visto que apenas alguns grupos econômicos possuem a voz central e, portanto, a constituição da realidade da saúde sofre as intervenções dos interesses desses grupos. Também vale destacar que as autoras pensam que, no Brasil, a bandeira do direito à comunicação e à pluralidade de ideias não se encontra tão amadurecida e não é tão desejada. Mesmo com tais desafios e a desigualdade de discursos nos meios de comunicação, as autoras acreditam na possibilidade de estratégias enunciativas que "tornem possível construir 
lugares de interlocução mais autorizados, mais legitimados, alterando assim a composição de forças no cenário midiático” (ARAÚJO; CARDOSO, 2007, p. 103).

Outra diretriz dada é a do controle social, com a participação dos cidadãos nas definições e na gestão das políticas públicas de saúde, de maneira que garanta os interesses da sociedade. Nesse caso, “não há separação entre Estado e sociedade; pelo contrário, leva-se às últimas consequências a percepção de que o estado é parte da sociedade” (ARAÚJO; CARDOSO, 2007, p. 104).

As autoras acreditam ser possível “abandonar velhas posturas” que se limitam a criticar a mídia como reduto das ideologias dominantes, e pensar na nova realidade que existe e, portanto, “exige novos olhares e a abertura de novas possibilidades” (ARAÚJO; CARDOSO, 2007, p. 104). Entre as novas modalidades de comunicação adotadas, uma das principais é o uso do marketing social na saúde, que consiste na aplicação de estratégias de marketing e temas de interesse social, associados a "[...] processos de persuasão quanto à adoção de determinados comportamentos e atitudes” (ARAÚJO; CARDOSO, 2007, p. 109). A estratégia é criticada por Araújo e Cardoso (2007, p. 110), pois, embora tais estratégias falem da identificação dos problemas sociais, partem do "mesmo pressuposto comportamental desenvolvimentista, que é a de que os problemas são causados por atitudes e predisposições dos indivíduos.” E o que as autoras afirmam é exatamente o contrário: as determinações de saúde são muito mais amplas do que atitudes individuais ou mesmo grupais.

Em contrapartida, a comunicação ideal é aquela que considera os contextos, os processos políticos envolvidos no estabelecimento de prioridades, bem como as condições sociais, materiais e institucionais; que leva em conta as condições subjetivas de produção de sentidos, e tem a percepção das relações de poder que são determinadas pelos processos e práticas comunicativas; que também precisa considerar os silêncios, as ausências, de forma a amplificar as vozes.

Além disso, a comunicação de interesse público é “calcada no discurso de responsabilidade social”, proposta que viabiliza que as empresas, tanto públicas quanto privadas, “devem utilizar seu potencial comunicativo para ir além da simples divulgação de produtos ou construção de imagem institucional” (ARAÚJO; CARDOSO, 2007, p. 112).

Outra proposta comunicativa reforçada é a da rede como espaço de exercício de poder, pois possui virtudes democratizantes e propiciadoras da interdisciplinaridade, intersetorialidade, interlocução e intercâmbio. A proposta da rede é um objetivo a ser perseguido, uma vez que possibilita a produção, a apropriação e a circulação dos vários 
discursos sociais. Soma-se ao fato de que a rede é um modo de produção dos sentidos “potencialmente mais democrático que outros dominantes na saúde, cuja fala emana sempre dos núcleos centrais” (ARAÚJO; CARDOSO, 2007, p. 114). Sua dinâmica "potencializa a negociação dos sentidos” - ainda que, por ser uma discussão recente, os modelos de comunicação em rede são, "como qualquer outro espaço, lugares de manutenção ou transformação das relações de poder” (ARAÚJO; CARDOSO, 2007, p. 116). Nesse sentido, não se deve superestimar as novas possibilidades de comunicação, visto que tais tecnologias não dissolveram as desigualdades sociais ou as relações de poder.

Os questionamentos e estratégias colocados pelas autoras valem para uma reflexão teórica referente à maneira como são estruturados os planejamentos e modelos comunicacionais para C\&S. E, na prática comunicativa, diretrizes também são dadas - dessa vez, por Bueno (1996) - tratadas no tópico seguinte.

\subsection{Como os meios de comunicação retratam a saúde?}

Em complemento à necessária modificação no modelo comunicacional de saúde, Bueno (1996), no volume “Comunicação para a saúde: uma experiência brasileira”, coloca contribuições práticas para que se aprimore a abordagem comunicacional do tema. Para ele, o perfil da comunicação para a saúde no Brasil é, resumidamente, baseado nas seguintes características: fragmentação, preconceito, reducionismo, mitificação e corporativismo. No que tange ao estilo, o Brasil possui duas maneiras de se fazer comunicação para a saúde, que são: as campanhas de âmbito nacional; e a veiculação de informações sobre Medicina/Saúde em reportagens, colunas ou artigos, em meios eletrônicos e/ou massivos (BUENO, 1996).

Essas possibilidades “encerram gargalos e distorções”, porque estão vinculadas a fatores como a "proposta editorial dos veículos, a atuação corporativa da chamada ordem médica, a ingenuidade e o despreparo de jornalistas e comunicadores em geral, a omissão dos governantes e o lobby da indústria da saúde” (BUENO, 1996, p. 14).

Quanto às características anteriormente citadas da mídia para a saúde, Bueno (1996) dá o seguinte parecer:

1) Fragmentação: “as notícias e reportagens fluem na mídia como peças de um quebra-cabeça que nunca se completa” (BUENO, 1996, p. 15), o que gera confusão, pois o cidadão fica preso num conjunto formidável de dilemas. Isso ocorre menos porque a ciência “ainda não deu resposta confiável às questões de saúde, e mais porque a mídia oscila em função de espasmos de divulgação, pouco preocupada em avaliar a qualidade das 
informações que chegam a ela ou de verificar o interesse das fontes que as produzem” (BUENO, 1996, p. 15). Por ser uma característica da mídia notadamente mercadológica, a fragmentação viabiliza o maniqueísmo do bem contra o mal, como se cada dilema fosse um grande espetáculo.

2) Foco na doença: cria um caráter fatalista, desviando o olhar de que faltam políticas públicas sobre a saúde, e elegem os micro-organismos como vilões. Ao concentrar o foco na doença, as "matérias não permitem a elaboração de uma proposta informativa que privilegie a prevenção, a educação para a saúde e o debate sobre as condições econômicas e socioculturais que podem conduzir a uma melhor qualidade de vida” (BUENO, 1996, p. 16).

3) Visão preconceituosa das terapias alternativas: com raras exceções, a mídia ignora ou mantém sob suspeita as medicinas alternativas - acupuntura, homeopatia, medicina oriental; possui uma visão cientificista, que se apega a determinadas convicções ou paradigmas; exclui soluções “[...] que não se enquadram nas concepções ocidentais de doença e cura e do homem como um somatório de órgãos [...] e aparelhos ou sistemas” (BUENO, 1996, p. 17); não admite o ser humano como um ser integral; não faz concessões a ações que se situam fora do campo da técnica e da ciência; por fim, “[...] ridiculariza as emoções como sintoma da fragilidade humana e encara a opção não materialista como desvio da normalidade” (BUENO, 1996, p. 17).

4) Notícia como espetáculo: a medicina e a saúde se prestam a soluções miraculosas, prometendo curas, “[...] desvendando os mistérios do corpo e da mente e propagando medicamentos e equipamentos que integram o aparato tecnológico à disposição dos médicos” (BUENO, 1996, p. 17). O autor continua, afirmando que a

espetacularização da notícia de saúde permite que se fantasie a realidade e [...] ao invés de promover a confiança no talento humano, alimenta, a médio prazo, a desesperança, ao mesmo tempo em que desinforma, estimula o consumo inconsciente de medicamentos e desarma os espíritos para a importância da prevenção. (BUENO, 1996, p. 17).

5) Mito da técnica onipotente: vende-se a ideia de milagre, com a finalidade de viabilizar a inquestionável onipotência da técnica. Por outro lado, a divulgação espetaculosa de erros médicos leva à perda da credibilidade desses médicos, bem como o surgimento dos 'novos gurus (os curandeiros modernos)', ressalta Bueno (1996).

6) Legitimação do discurso da competência: essa característica coloca o profissional de saúde, o especialista, “como a única fonte capaz e com legitimidade para expressar conceitos relacionados com esta área, descartando a conveniência de outras falas” (BUENO, 1996, p. 18). Tal visão corporativista resume que o saber técnico fica dividido nos que o 
dominam ou não, ou seja, quem tem o discurso da competência "[...] faz parte do clã; aqueles que não o manipulam não têm o aval da tribo” (BUENO, 1996, p. 19). Esse discurso cria um relacionamento verticalizado, não democrático, "exclui o saber popular e a experiência transmitida pelas gerações ao longo do tempo, por não estarem revestidos da lógica científica e não terem obtido a aprovação da Academia” (BUENO, 1996, p. 19). Bueno (1996) acredita que não se deve subestimar os profissionais da medicina, mas que a Medicina e a saúde não devem constituir-se em preocupação e em espaço de reflexão apenas para os profissionais desta área.

Com o objetivo de avançar o quadro apontado, Bueno (1996, p. 25-28) propõe algumas estratégias, tais como:

a) Tom coloquial: a adoção do coloquialismo cria intimidade com o leitor e promove a remoção do relacionamento verticalizado entre o especialista e o leigo;

b) Uso do bom humor: é essencial para romper com a formalidade dos textos científicos. Com o recurso, pretende-se mostrar ao leitor que os termos científicos não são estranhos apenas a ele e que o autor do texto também se incomoda com algumas descrições e termos técnicos;

c) Didatismo: o compromisso com o didatismo mira esclarecer os jargões técnicos, e serve para remover o tom de aula de ciências que muito circunda o discurso científico;

d) 'Ganchos' com a atualidade: na divulgação científica, a cultura jornalística demonstrou que a ‘colagem’ da informação científica a uma pauta de atualidade aumenta bastante o índice de leitura. O próprio trabalho de contextualização contribui para despertar o interesse, para incentivar a leitura e para efetivar uma nova proposta de comunicação para a saúde;

e) Adequação ao formato: tentar diminuir o tamanho dos textos e inserir elementos gráficos, bem como valer-se das possibilidades multimidiáticas, por meio da inserção de elementos como vídeos, infográficos, imagens, etc.

O autor acredita que a informação em saúde se constitui em uma ação pedagógica, sendo necessário buscar a informação correta, a partir de fontes gabaritadas. Além disso, a informação deve trazer à tona questões como a importância de uma relação transparente no relacionamento entre médico e paciente, com obediência a princípios éticos, e inclusive tratar de assuntos diversificados, como o perigo da automedicação e as vantagens da prevenção. 


\subsection{Comunicação e saúde: o que estamos discutindo?}

Partindo dos princípios da Promoção da Saúde e da Saúde Coletiva, reconhece-se que as condições de saúde/doença não são somente atribuição individual ou causa do estilo de vida moderno, mas igualmente relacionada ao contexto cultural e político específico da sociedade em que o indivíduo se insere. Nesse sentido, saúde é algo que também se produz socialmente, e cada sociedade tem uma concepção diferente de qualidade de vida, que perpassa por aspectos subjetivos e objetivos, ainda que se adotem como parâmetros as referências propostas pelo IDH.

Conforme afirmam Araújo e Cardoso (2007), Minayo (1992) e Kucinski (2000), vale reforçar que a desigualdade social é o pano de fundo e a raiz de grande parte dos problemas que envolvem a saúde do indivíduo. Araújo e Cardoso (2007) também ressaltam que, embora aparente haver um manto de "bondade" no campo da saúde, a área é envolta por diversas disputas decorrentes dessa mesma desigualdade. Essas considerações trazem à tona uma politização do campo, bem como ampliam e fomentam a discussão do assunto.

Para que se efetivem as diretrizes propostas pela Promoção da Saúde, Westphal (2007), e Fernandez e Mendes (2007, p. 55-58) destacam dois elementos: a intersetorialidade e a participação social. Esses fatores apresentam-se como possibilidades de inserção política dos diversos atores sociais nas decisões de como se darão as políticas públicas de saúde, conforme salientaram Araújo e Cardoso (2007).

Complementando as falas anteriores, Bógus e Westphal (2007) reafirmam que um dos elementos que fortalecem as ações de Promoção da Saúde são os movimentos sociais ligados à área. Tal reconhecimento é importante, visto que mostra como a cidadania constitui-se em uma articulação entre cidadãos e Estado, sendo que aqueles cobram do Estado melhores condições de qualidade de vida. Isso leva à compreensão de que não há separação entre Estado e sociedade, mas que o Estado é parte da sociedade.

No que concerne às políticas públicas de saúde, Kucinski (2000) e Araújo e Cardoso (2007) salientam que há escolha de prioridades, baseadas em diversas forças, como política ou financeira. Isso deixa o Estado - e, por consequência, a mídia - em posições frequentemente contraditórias: ora favorecendo e fomentando a cidadania e os direitos sociais, ora beneficiando alguns grupos, com interesses privados.

Araújo (2004) aponta a existência de vozes no centro do discurso, enquanto outros se encontram na periferia, fator que também demonstra uma desigualdade. Soma-se ao fato de que os setores de saúde colocados no centro do lugar da interlocução são o saber médico, técnico e científico, favorecimento que acarreta determinados saberes, aparecendo como as 
fontes legitimadoras da verdade. Enquanto isso, os demais saberes, como os populares ou da Saúde Coletiva, são alijados do sistema comunicativo, isto é, colocado na periferia do discurso comunicacional.

Contudo, tal condição de discurso desigual demonstra que, enquanto houver apenas um discurso central, seja no âmbito dos formuladores de políticas públicas, seja na mídia, haverá um leque de prioridades - restrito a esse grupo - coexistindo com diversas vozes periféricas em silêncio, cujas necessidades e práticas são perdidas. Em consequência, as políticas voltadas para esse grupo periférico ocorrem de acordo com a visão centralizadora de que há um público ignorante e que deve ser educado.

Em contrapartida, Kucinski (2000) defende uma posição mais radical, pois considera que as campanhas comunicacionais do Estado - que envolvem opções ideológicas e, portanto, não são neutras - objetivam, em última instância - a continuidade das desigualdades, neutralizando-as com campanhas massivas em saúde, como a vacinação.

As questões acima mencionadas devem ser pressupostos para a formação do comunicador que aborda a temática da saúde, a fim de que amplie seu arsenal analítico para investigar os fatores que possibilitem a ocorrência de um quadro doente. Isso porque um comunicador crítico da área pode fomentar discussões em torno de patologias sociais, decorrentes das condições ambientais ou socioeconômicas.

Contudo, tanto Kucinski (2000) como Araújo (2004) destacam que os motivos da ineficiência de determinada campanha comunicacional em políticas públicas de saúde se dão pela falta de conhecimento na relação entre emissor e receptor, bem como pelo desconhecimento das possibilidades de discursos, que se encerram nos segmentos da sociedade. A ingenuidade dos comunicadores, somada à ausência de ampliação da discussão para os determinantes sociais envolvidos, constitui-se em entraves na abordagem. Estas limitações levam às características apontadas pelo autor, como fragmentação, preconceito, reducionismo, mitificação e corporativismo. (BUENO, 1996).

Araújo e Cardoso (2007) identificam que, para modificar o quadro atual da C\&S são necessárias ações tanto no âmbito individual como no coletivo: na instância individual, o comunicador deve ser crítico, permitindo que outras vozes circulem, bem como deve também acionar seu perfil profissional analítico quanto às campanhas que visem à saúde. Outro ponto é que o comunicador não deve fazer uma transferência de conhecimento de forma unidirecional, sem o dialogismo. Isso porque as pessoas já possuem referências prévias do significado de saúde/doença. Portanto, ao tratar do tema, “é importante voltar-se ao termo 
‘diretrizes', ou seja, aos princípios organizativos, não às regras prontas” (ARAÚJO; CARDOSO, 2007, p. 35).

E, no âmbito coletivo, cabe uma descentralização de políticas públicas em comunicação, com o objetivo de viabilizar a entrada de discursos que se situam na periferia, para que caminhem em direção ao centro, de maneira multipolar e multidirecional (ARAÚJO, 2004). Essa pluralização permite que os cidadãos tenham ciência de que existem outras possibilidades de se compreender a saúde, saindo do campo estritamente individual, e entrando nas questões sociais e passíveis de serem modificadas, com base em políticas que envolvem não somente o saber médico, mas uma intersetorialidade de profissionais (MINAYO, 1992).

Somado ao modelo comunicacional proposto por Araújo e Cardoso (2007), Bueno (1996) elenca dicas para se tratar da temática da saúde. Embora o livro tenha sido publicado em 1996, nota-se uma permanência das problemáticas colocadas pelo autor, não somente no jornalismo de saúde, mas também nos demais editorias.

As propostas de melhorar o discurso na área, como coloquialismo, bom humor, didatismo, adequação ao formato e ganchos com a realidade, são elementos que podem fomentar o interesse do cidadão. Contudo, as dicas de nada adiantam se as demais características permanecerem, isto é, a fragmentação, preconceito, reducionismo, mitificação e corporativismo. Nessa medida, por mais que se tenha um texto comunicativo baseado no coloquialismo, gancho com a atualidade, didatismo, bom humor e adequação ao formato, tais diretrizes não favorecem o cerne da questão, se o discurso de saúde continuar fragmentado e preconceituoso.

Ainda assim, o modelo proposto por Araújo (2004) e as dicas fornecidas por Bueno (1996) visam minar esse tipo de cobertura. Entretanto, vale destacar que a cobertura midiática é um reflexo do sistema político social vivenciado na contemporaneidade, isto é, baseado na fragmentação, desigualdade de sujeitos no espaço público, culpabilização dos indivíduos e ausência de questionamentos da prática médico/científica. Cabe ao comunicador adotar uma postura ética e crítica, que viabilize uma estratégia em comunicação que objetive ampliar os discursos, evitando a mera consulta ao aval científico e médico, pois estes não são os únicos solucionadores dos processos que envolvem a saúde e a doença (MINAYO, 1992). 


\section{Alimentação e comunicação}

Com base nas fontes pesquisadas, pode-se afirmar que os veículos midiáticos abordam a alimentação, sobretudo como questão de saúde e/ou ciência. Contudo, sabe-se também que o tema envolve uma série de fatores sociais e culturais, como a cultura alimentar, bem como recai na importância de se abordarem os conceitos de segurança alimentar e nutricional. Partindo desses pressupostos, o capítulo trata dos principais elementos que conectam a temática da alimentação e da comunicação. Para tanto, foi adotada a seguinte divisão:

1) Segurança Alimentar e Nutricional - destaque para a noção de Segurança Alimentar e Nutricional (SAN), conceito que objetiva assegurar o Direito Humano à Alimentação Adequada (DHAA), e Soberania Alimentar, bem como o contexto histórico dos marcos mencionados. No contexto nacional, serão elencados os principais pontos das diretrizes alimentares oficiais para os brasileiros, encontrados no 'Guia Alimentar para a População Brasileira’ (BRASIL, 2006).

2) Mídia e alimentação - trata dos paradoxos midiáticos na abordagem da alimentação, iniciando com Michael Pollan, jornalista especializado no assunto e autor das obras: $O$ dilema do onívoro (POLLAN, 2007); Em defesa da comida: um manifesto (POLLAN, 2008); e Regras da Comida (POLLAN, 2010). Também especialistas no assunto são e Jakobson e Nestle (2000), que dissertam sobre políticas públicas em alimentação.

3) Diretrizes de alimentação - serão elencados os subsídios para que se aborde a alimentação, cujos tópicos são divididos com base na análise temática. A compilação se dará com Pollan (2007; 2008), os documentos da Organização Mundial da Saúde (OMS), e da Organização das Nações Unidas para Agricultura e Alimentação (FAO), o “Guia Alimentar para a população brasileira” (BRASIL, 2006), bem como as demais referências estudadas para esta pesquisa.

\subsection{Segurança Alimentar e Nutricional: conceitos}

No Brasil, o conceito de Segurança Alimentar e Nutricional (SAN) encontra-se em permanente construção e seus princípios foram elaborados para que se efetive o Direito Humano à Alimentação Adequada (DHAA) e à Soberania Alimentar. A SAN é mais bem pontuada como noção porque engloba, dentre outras temáticas, questões culturais, sociais e ambientais relacionadas ao alimento. 
Para compreender seus significados e contexto histórico, adotaram-se como referências principais os documentos "Construção do Sistema e da Política Nacional de Segurança Alimentar e Nutricional: a experiência brasileira” (CONSEA, 2009), elaborado pelo Conselho Nacional de Segurança Alimentar e Nutricional, órgão criado em 1993 e que hoje é o principal articulador nacional para a questão. Também é usado o "Guia Alimentar da População Brasileira”, publicado pela primeira vez em 2006, e que contém as primeiras diretrizes alimentares oficiais para os brasileiros (BRASIL, 2006). A terceira referência é o livro “Segurança Alimentar e Nutricional: Significados e apropriações”, em que Costa (2011) aborda as diferentes noções de SAN.

O conceito de SAN adotado baseia-se no referencial teórico advindo das recomendações da Política Nacional de Alimentação e Nutrição - PNAN (BRASIL, 2003) e da Organização Mundial da Saúde, adotadas também pelo CONSEA (2010) e Guia Alimentar para a População Brasileira (BRASIL, 2006). Com base na definição proposta na II Conferência de Segurança Alimentar e Nutricional de 2004, em Olinda, entende-se a Segurança Alimentar e Nutricional (SAN) como

o direito de todos ao acesso regular e permanente a alimentos de qualidade, em quantidade suficiente, sem comprometer o acesso a outras necessidades essenciais, tendo como base práticas alimentares promotoras de saúde, que respeitem a diversidade cultural e que sejam social, econômica e ambientalmente sustentáveis. (CONSEA, 2009, p. 36)

A concepção de Direito Humano à Alimentação Adequada possui duas dimensões indivisíveis, que são a) o direito de estar livre da fome e da má nutrição; e b) o direito à alimentação adequada, sendo dever do poder público respeitar, proteger, promover e prover, além de monitorar e avaliar a realização desse direito (CONSEA, 2009, p. 14), garantindo todos os mecanismos para que esse direito se cumpra.

Já a Soberania Alimentar é o direito de a sociedade definir como se darão suas políticas de produção, distribuição e consumo de alimentos, de maneira que se respeite o meio ambiente, a agricultura familiar e a preservação dos hábitos alimentares específicos de cada região (CONSEA, 2009, p. 36).

No Brasil, dá-se o enfoque em SAN baseado na interface com outras áreas, caracterizando suas ações em vários âmbitos, cuja abrangência envolve a produção, comercialização, consumo, utilização biológica dos alimentos e suas relações com a saúde. Outro diferencial das práticas de SAN é o exercício da intersetorialidade, com abordagem transdisciplinar dos fenômenos sociais, bem como a questão do acesso aos alimentos como principal referencial para efetivar o DHAA (COSTA, 2011). 
Vale destacar as principais interfaces da SAN, que são: Saúde, Renda, Gênero, Produção de Alimentos, Indústria, Mídia, Abastecimento, Consumo e Meio Ambiente. Em cada interface, pode-se dar destaque às seguintes considerações de Costa (2011):

1) Saúde: no Brasil, as Doenças Crônicas não Transmissíveis (DCNT) foram responsáveis pelo maior número de óbitos, bem como o maior volume de despesas com assistência hospitalar no Sistema Único de Saúde (SUS), totalizando 69\% dos gastos (COSTA, 2011, p. 49). A saúde também é comprometida por conta da transição nutricional, cujos índices de subnutrição convivem agora com a evolução do sobrepeso e da obesidade: enquanto 49\% da população adulta encontra-se com sobrepeso, levando a um aumento de doenças crônicas não transmissíveis, 30\% da população sofre algum nível de insegurança alimentar (IBGE, 2010a). Tais estatísticas representam mais um reflexo da desigualdade social nas condições de saúde da população do país.

2) Renda: a questão do acesso ao alimento levanta obstáculos, principalmente, pela renda das famílias mais pobres, que possuem dificuldade em adquirir o mínimo para sua sobrevivência. É possível observar a desigualdade do acesso ao alimento pelo fato de o Brasil ser o quarto maior exportador de alimentos, mas é o sexto maior em subnutrição do mundo (PROJETO EDUCANDO COM A HORTA ESCOLAR, 2009c, p. 20). O Guia Alimentar (BRASIL, 2006, p. 157) salienta que existe um perfil de indivíduos com maior risco para a insegurança alimentar e nutricional, sendo mais graves os de menor renda familiar e os de baixa escolaridade.

Para mensurar esse risco, foi criado no Brasil um indicador, intitulado Escala Brasileira de Insegurança Alimentar (EBIA), em que se avalia "a capacidade de acesso das famílias às refeições habituais nos aspectos quantitativo e qualitativo, incluindo a percepção dos seus membros sobre a capacidade de assegurarem esse acesso no futuro próximo” (CONSEA, 2009, p. 47). Com base nos critérios do EBIA, a Pesquisa Nacional de Amostra por Domicílio (PNAD) de 2009 e publicado em 2010, indicou que 69,8\% dos domicílios se encontravam em situação de segurança alimentar, enquanto que 30,2\% dos domicílios se encontravam com algum grau de insegurança alimentar, dos quais $5 \%$ na forma mais grave (IBGE, 2010b, p. 33).

3) Gênero: há uma ambiguidade em relação ao papel na mulher na provisão do alimento. Isso porque, embora já ocupe o mercado de trabalho, as mulheres continuam responsáveis pelo ambiente doméstico e, por consequência, pela alimentação. Em contrapartida, ainda não ocupam grande parte das posições que compõem arenas decisórias em políticas que afetam 
seu cotidiano - fator que contribui ainda mais para que a alimentação acabe recaindo sob sua responsabilidade.

4) Produção de alimentos: nas últimas décadas, ocorreu uma alteração radical dos modos locais de produção e consumo de alimentos, com a consequente homogeneização da cultura alimentar. O padrão do agronegócio gerou variados desenvolvimentos industriais, como pesquisas em nutrição; em contrapartida, trouxe uma uniformização de dietas, cuja abordagem desvaloriza a cultura de cada região, bem como os saberes agrícolas tradicionais.

5) Indústria: do ponto de vista do consumo, "a ampla maioria das iniciativas ligadas à luta contra a fome e a insegurança alimentar não questionam o valor nutritivo nem a crescente massificação e descaracterização cultural do padrão alimentar” (COSTA, 2011, p. 77). A industrialização de todo o sistema alimentar acarreta aditivos alimentares que objetivam reduzir os custos, bem como o aumento da durabilidade e satisfação do paladar. Contudo, tais critérios não respondem às reais necessidades nutricionais do ser humano, podendo, ainda, comprometer sua saúde.

O alimento altamente processado já recebeu inclusive o nome de “objeto comestível não identificado” (OCNI), alcunha dada pelo pesquisador Claude Fischler (1990 ${ }^{9}$ citado por COSTA, 2011, p. 78). Vale destacar também a concentração cada vez maior da cadeia alimentar nas mãos de poucas indústrias, que empregam pouca parcela da força de trabalho. Para se interpor a essa prerrogativa, Costa (2011) aponta a necessidade de uma globalização cooperativa, com a defesa do Estado diante dos interesses da indústria transnacional. A “globalização cooperativa representa um esforço [...] para reconstruir a economia global de baixo para cima, com base em sociedades mais saudáveis e equitativas” (COSTA, 2011, p. 80-1).

6) Mídia: os meios de comunicação são os grandes fornecedores de informações sobre os alimentos. Contudo, atendendo a interesses comerciais, induzem à adoção de hábitos que têm mais relação com “[...] marca, embalagem e lucro dos proprietários do que com saúde e nutrição” (COSTA, 2011, p. 81), bem como propaga o consumo de produtos importados, trazendo a ideia de que são melhores do que os produzidos localmente. Costa (2011) reforça que os meios de comunicação não podem ser usados somente para difundir informações que atendam às demandas de seus anunciantes, mas, devem também incentivar os indivíduos a se alimentarem melhor para terem saúde.

7) Abastecimento: o CONSEA afirma que o abastecimento é um “elemento nuclear” das estratégias e políticas de SAN, visto que permite, simultaneamente, “a ampliação do acesso

\footnotetext{
${ }^{9}$ FISCHLER, C. L’Homnivore: le goût, la cuisine et le corps. Paris: Odile Jacob, 1990. 440 p.
} 
aos alimentos de qualidade e a promoção de uma alimentação saudável e adequada.” É relevante destacar a necessidade de políticas de abastecimento que também possam fornecer formas socialmente equitativas e ambientalmente sustentáveis de produção e comercialização de alimentos, bem como a diversificação de hábitos alimentares (COSTA, 2011, p. 85).

8) Consumo de alimentos: a dieta alimentar brasileira empobreceu-se por conta de um modelo de produção que, “[...] juntamente com a concentração urbana e o apelo midiático, modificou profundamente o consumo” (COSTA, 2011, p. 87). A III Conferência de SAN determina que a valorização do alimento mais como mercadoria e fonte de lucro do que como “elemento essencial à vida” gera “impactos negativos sobre os modos de vida, a soberania e a segurança alimentar e nutricional das populações urbanas e rurais”, bem como coloca em risco a biodiversidade e o patrimônio cultural alimentar (COSTA, 2011, p. 87). Com isso, o comportamento alimentar vem sendo substituído por produtos globais, o que tem levado a “[...] um empobrecimento dos conhecimentos sobre ingredientes e tecnologias caseiras de preparo de alimentos e a uma ‘erosão dos sabores’ de toda a humanidade” (COSTA, 2011, p. 94).

9) Meio ambiente: as crises alimentares que atingem o globo são consequências de um modelo de desenvolvimento econômico e político. Nesse sentido, a busca pela sustentabilidade procura rever os padrões de consumo e produção, visando o consumo sustentável. Consumo sustentável remete ao fornecimento de serviços e produtos que atendam as necessidades básicas, fornecendo melhor qualidade de vida; ao mesmo tempo, minimiza na visão da UNEP (2005 citado por COSTA, 2011, p. 94), “[...] o uso de recursos naturais e materiais tóxicos, como também a produção de resíduos e a emissão de poluentes no ciclo de vida do serviço ou do produto, tendo em vista não colocar em risco as necessidades das futuras gerações”. Ao observar as interfaces da SAN acima apresentadas, é possível avaliar que a alimentação é questão complexa, envolve problemas sociais e ambientais, determinados por fatores interdependentes. Sendo assim, é necessária uma abordagem intersetorial e interdisciplinar, dada a insustentabilidade dos padrões atuais para produção e consumo alimentar.

A autora também destaca a importância de se usar o termo "cidadania alimentar”, onde as escolhas saudáveis se dariam com base na compreensão dos fatores condicionantes do sistema alimentar, segundo Costa (2011, p. 278). Essa visão de cidadania e seu exercício implicam “em autonomia e liberdade responsável, participação na esfera política, democrática e na vida social” (COSTA, 2011, p. 295). Na concepção da cidadania alimentar, há 
necessidade de se recorrer a outros campos do conhecimento para tratar dos alimentos, como sociologia, história, antropologia, agronomia e ecologia.

Nos diversos setores da sociedade civil, também é necessário uma formação em SAN e educação nutricional, uma vez que há uma associação direta entre mudança de atitude e aprendizado de comportamentos saudáveis, tendo o conhecimento como 'uma condição única para se operar mudanças” (COSTA, 2011, p. 286).

Em suas conclusões, Costa (2011, p. 301) finaliza que Segurança Alimentar e Nutricional é dada como noção, estratégia orientadora e como objetivo de política pública, sendo um dos grandes desafios do país no sentido de repensar novas relações entre sociedade e natureza. Mesmo com diversos emblemas e desafios, a inserção do tema da alimentação saudável à noção de SAN permite que se tenha maior contextualização do que significa o ato de se alimentar de maneira saudável, pensando em suas diversas implicações que envolvem não só saúde, mas também o pensamento crítico em relação aos padrões insustentáveis de consumo e produção de alimentos.

Após a apresentação das noções SAN e suas interfaces, o próximo tópico destacará os processos e marcos históricos que culminaram no agendamento político do tema, marcados por pactos, conferências e militâncias da sociedade civil.

\subsubsection{Contexto histórico da SAN}

Quanto aos marcos históricos, que norteiam o agendamento da noção de Segurança Alimentar e Nutricional, nota-se que o conceito é historicamente recente e com constante reformulação de seus significados e focos de atuação. No contexto mundial, o início do debate sobre segurança alimentar e nutricional se deu a partir do dia 16 de outubro de 1945, Dia Mundial da Alimentação, marcado pela criação da Organização das Nações Unidas para a Agricultura e a Alimentação (FAO). Com sede em Roma, a principal função da entidade é atuar como um fórum neutro entre países, para que se possam discutir estratégias e políticas no sentido de combater a fome e efetivar as diretrizes da segurança alimentar e nutricional.

Três anos depois, em 1948, foi consolidada a Declaração Universal dos Direitos Humanos (DUDH), uma reação de consciência política ao fenômeno da pobreza. E, para operacionalizá-la, em 1966, o Haute-Commissariat pour le Droit de l'Homme (1966).

Foram elaborados dois Pactos Internacionais: o Pacto Internacional dos Direitos Civis e Políticos (DCP) e o Pacto Internacional dos Direitos Econômicos, Sociais e Culturais 
(PIDESC), tendo este último incluído o Direito Humano à Alimentação Adequada (DHAA) em suas diretrizes. Tal inclusão coloca a alimentação como um Direito Humano, reafirmado no artigo 11 do Pacto Internacional sobre Direitos Econômicos, Sociais e Culturais. O Pacto fora aberto a adesões em 1966 e passou a vigorar em 1976. No Brasil, entrou no ordenamento jurídico em 1991. Vale destacar os seguintes pontos do artigo 11:

1. Os Estados membros que aderem ao presente pacto reconhecem o direito de toda pessoa a um nível de vida suficiente para ela e sua família, incluindo alimentação, vestuário e abrigo suficientes, bem como uma melhoria contínua de sua condição de vida. Os Estados membros tomarão medidas para assegurar a realização deste direito e reconhecem a importância essencial de uma cooperação internacional de forma livre e consensual para este efeito.

2. Os Estados membros, pelo presente pacto, que reconhecem o direito fundamental de toda pessoa de estar livre da fome, adotarão, individualmente e por meio de cooperação internacional, as medidas necessárias, incluindo programas concretos: a) para melhorar os métodos de produção, de conservação e distribuição de porções alimentares pela plena utilização dos conhecimentos técnicos e científicos, para a difusão de princípios de educação nutricional e para o desenvolvimento ou a reforma de regimes agrários, de modo a assegurar ao máximo a valorização e a utilização dos recursos naturais; b) para assegurar uma distribuição equitativa dos recursos alimentares mundiais com relação às necessidades, tendo em conta os problemas que se colocam tanto aos países importadores quanto aos países exportadores de alimentos. (HAUTE-COMMISSARIAT POUR LE DROIT DE L'HOMME (1966 citado por CUSTODIO, 2009, p. 31).

Apesar dessas determinações, na década de 1980, constatou-se que o aumento da disponibilidade de alimentos não foi capaz de sanar o problema da fome, mostrando que o problema maior era social, isto é, de acesso aos alimentos. Tal constatação fez com que a FAO e outros órgãos adotassem a questão do acesso como primordial para a consolidação plena da segurança alimentar e nutricional (COSTA, 2011, p. 118). No mesmo período, dá-se início ao movimento de "Promoção da Saúde", conceito que entende que a saúde está articulada a interesses econômicos, bem-estar social, bem como ao desenvolvimento econômico e social ${ }^{10}$.

Outro marco que pode ser mencionado é a Segunda Conferência Internacional sobre Promoção de Saúde (1988), ocorrida em Adelaide, na Austrália, cujo objetivo era demonstrar o papel das políticas públicas na resolução dos problemas de saúde. Como política pública em SAN, recomendou-se aos governos a implementação de ações para ter maior poder de compra

\footnotetext{
${ }^{10}$ A definição mais aprofundada de "Promoção da Saúde” consta no Capítulo 5, “Comunicação e Saúde”.
} 
no mercado de alimentos, assegurando estoques e controle, a fim de garantir acesso a uma alimentação saudável à população (COSTA, 2011, p. 101).

Já um dos principais eventos de segurança alimentar e nutricional foi a Declaração de Roma sobre a Segurança Alimentar Mundial e Plano de Ação, que aconteceu na Cúpula Mundial da Alimentação em 1996 (FOOD AGRICULTURE ORGANIZATION OF UNITED NATIONS, 1996). O evento possibilitou a inserção do tema na pauta de discussão dos governos, e Chefes de Estado e Governo reafirmaram compromissos no combate à fome mundial e acesso à alimentação plena. Entre os planos de ação propostos na Declaração de Roma, destacam-se:

21. Objetivo 2.3 - Assegurar que o fornecimento de alimentos seja seguro, física e economicamente acessível, apropriado e adequado às necessidades energéticas e nutricionais da população.

22. Objetivo 2.4 - Promover o acesso de todos, especialmente dos pobres e membros dos grupos vulneráveis e desfavorecidos, a uma educação básica e aos cuidados de saúde primários, de modo a fortalecer as suas capacidades de autonomia. (FOOD AGRICULTURE ORGANIZATION OF UNITED NATIONS, 1996)

No Brasil, a mobilização em torno do tema data de meados da década de 1980, quando ocorreram dois marcos para que se estabelecesse um sistema e uma política nacional de segurança alimentar e nutricional. O primeiro, mais técnico e criado pelo Ministério da Agricultura, foi o documento "Segurança Alimentar - proposta de uma política de combate à fome”, de 1985.

Em 1986, a sociedade civil organizou a I Conferência Nacional de Alimentação e Nutrição (ICNAN), cujo objetivo era maior mobilização em torno de temas como segurança alimentar e qualitativo nutricional (CONSEA, 2009, p. 24). Neste ano, ocorreu como parte do processo da $8^{\text {a }}$ Conferência Nacional de Saúde, e contou com a participação de representantes governamentais e não governamentais.

Na ICNAN, o conceito inicial de segurança alimentar e nutricional foi ampliado ao incorporar, às questões da produção agrícola e do abastecimento, outras esferas - como acesso e qualidade dos alimentos e carências nutricionais. Nesta conferência, surgiu a proposta de se criar um conselho nacional de alimentação e nutrição vinculado ao Ministério da Saúde, bem como a elaboração de um sistema de segurança alimentar e nutricional sob coordenação do Ministério do Planejamento. As duas propostas se dariam com a participação da sociedade civil, e a implantação dessa estrutura foi proposta também aos Estados, “com a finalidade de se ter uma garantia maior de acesso aos alimentos em quantidade de qualidade suficientes” (IPEA, 2010 p. 12). 
Com base na proposta de criação de um Conselho Nacional de Segurança Alimentar e Nutricional (CONSEA, 2009, p. 73-74), os seguintes princípios foram delineados:

- Universalidade e equidade no acesso a uma alimentação adequada;

- Participação social em políticas intersetoriais e transparência;

- Respeito à soberania alimentar e garantia do direito humano à alimentação adequada e sua exigibilidade;

- Produção camponesa e familiar como componente essencial na construção da soberania e segurança alimentar e nutricional;

- Solidariedade, complementaridade e cooperação entre os países e atores sociais envolvidos.

No entanto, poucos foram os resultados concretos da ICNAN, e o assunto voltou à pauta somente após o início dos anos 1990 (IPEA, 2010 p. 12), com a introdução do ideário da Promoção da Saúde no Brasil, em 1995.

Em 1999, foi homologada a Política Nacional de Alimentação e Nutrição (PNAN), cuja missão é contribuir com o conjunto de políticas do governo, visando à concretização do Direito Humano à Alimentação Adequada e à garantia da Segurança Alimentar e Nutricional. Ratificado em 2003, o PNAN (BRASIL, 2003) parte do princípio da intersetorialidade para a promoção da alimentação saudável, bem como a garantia de acesso à alimentação adequada, suficiente e segura (BRASIL, 2006).

Outro marco da SAN, no Brasil, foi o programa Fome Zero, de 2003, uma estratégia para assegurar o direito humano à alimentação adequada para pessoas com dificuldade de acesso aos alimentos (COSTA, 2011). Já no período de 2004 a 2007, o CONSEA teve destaque na construção da agenda sobre SAN, uma vez que foi o principal articulador entre governo e sociedade civil para a elaboração de propostas e diretrizes no que concerne a assuntos relacionados ao alimento e à alimentação.

Contudo, um empecilho que dificultava a efetivação de política públicas permanentes à alimentação era que, até 2010, o DHAA não era referenciado na Constituição Federal de 1988 como em outros âmbitos - o direito à vida, assistência social, saúde, ao salário mínimo, à educação, entre outros (CONSEA, 2009). O CONSEA liderou a inclusão da alimentação na Carta Magna, por meio da campanha 'Alimentação: um direito de todos', para que o Congresso Nacional aprovasse uma emenda constitucional que incluísse a alimentação como um direito social, assim como os outros direitos citados. Nessa campanha, mais de 50 mil pessoas participaram, assinando uma petição para que a alimentação fosse reconhecida como um direito. 
Outra medida liderada pelo CONSEA foi a criação do Sistema Nacional de Segurança Alimentar e Nutricional (SISAN), por meio da elaboração da principal lei sobre o assunto - a Lei Orgânica da SAN - Lei $\mathrm{n}^{0}$ 11.346, de 2006 (BRASIL, 2006). Juntamente com a participação do governo e da sociedade civil, a lei objetivava que fosse incluído o DHAA na Constituição (CONSEA, 2009).

Após esse cenário de lutas políticas - assinaturas de uma série de Tratados Internacionais que dispõem sobre o Direito Humano à Alimentação Adequada e a aprovação da Lei Orgânica da SAN - em fevereiro de 2010, o DHAA foi incluído no artigo $6^{\circ}$ da Constituição Federal, por meio da aprovação da PEC 047/2003.

Atualmente, o CONSEA é considerado o principal articulador da sociedade civil brasileira em segurança alimentar e nutricional. Possui, como princípios básicos para garantia da SAN, o direito ao acesso à terra, manejo dos recursos naturais pelos agricultores familiares, povos e comunidades tradicionais (COSTA, 2011, p. 112). Sua militância também envolve outras questões, como a regulação dos preços dos alimentos, o combate ao desperdício e aos modos que produção que prejudicam o meio ambiente e excluem os agricultores familiares (COSTA, 2011, p. 26). Além disso, faz parte da agenda do CONSEA a inserção das seguintes medidas: - educação alimentar e nutricional nos sistemas públicos; valorização da cultura alimentar brasileira; - formação em direito humano à alimentação e mobilização social para a conquista da SAN; - formação de produtores e manipuladores de alimentos (CONSEA, 2009, p. 64).

Além do CONSEA, outra construção coletiva para o tema da alimentação é o Guia Alimentar para a População Brasileira (BRASIL, 2006), resultado da colaboração pública de diversos participantes da sociedade. O documento representa um marco no cenário da temática para o país e, no tópico a seguir, serão mostrados os pontos de interesse para a pesquisa.

\subsubsection{Brasil: um Guia Alimentar para sua população}

No contexto nacional, o "Guia Alimentar para a população brasileira” consiste no primeiro documento com as diretrizes oficiais para a alimentação no Brasil. Publicado no ano de 2006 (BRASIL, 2006), possui referencial teórico advindo da Política Nacional de Alimentação e Nutrição - PNAN (BRASIL, 2003) e da Organização Mundial da Saúde $(\mathrm{OMS})^{11}$.

\footnotetext{
${ }^{11}$ Para mais informações sobre o PNAN e a OMS, ver em “Anexos”.
} 
O Guia é dividido em duas partes principais: Parte 1 - Referencial Teórico, no qual são explicitados os conceitos que orientaram a elaboração do guia, como SAN e DHAA. E a parte 2 do “Guia Alimentar para a população brasileira” (BRASIL, 2006), que possui os princípios e diretrizes de uma boa alimentação. Nessa parte, os princípios tratam de um posicionamento dos autores com relação ao significado de uma alimentação saudável, e as diretrizes fornecidas são mais voltadas para os profissionais de saúde, com dicas de tipos de alimentos, composição nutricional, entre outros.

Na Parte 1, o Guia afirma que é destinado a pessoas envolvidas com a saúde pública, bem como para formuladores e implementadores de ações governamentais, em áreas correlatas. Dessa forma, foi concebido para contribuir à “[...] prevenção das doenças causadas por deficiências nutricionais, para reforçar a resistência orgânica a doenças infecciosas e para reduzir a incidência de doenças crônicas não transmissíveis (DCNT), por meio da alimentação saudável” (BRASIL, 2006, p. 15).

O documento do governo (BRASIL, 2006) também entende que a questão da alimentação saudável, embora tenha o setor da saúde como um dos protagonistas envolve a integração de outros setores e atores sociais, propondo uma visão intersetorial. Outros pontoschave defendidos é de que a alimentação se dá em função de consumo de alimentos, e não de nutrientes; e uma alimentação saudável baseia-se em práticas alimentares com significado social e cultural.

Com relação aos nutrientes, reforça-se que, embora sejam importantes, os alimentos não podem ser resumidos a veículos deles, uma vez que os alimentos agregam significações culturais, comportamentais e afetivas que jamais podem ser desprezadas. Assim, “[...] o alimento como fonte de prazer e identidade cultural e familiar também é uma abordagem necessária para promoção da saúde” (BRASIL, 2006).

Há um alinhamento com o movimento para a 'Promoção da Saúde', e é possível notar esse pensamento conforme a seguinte consideração:

aquilo que se come e bebe não é somente uma questão de escolha individual. A pobreza, a exclusão social e a qualidade da informação disponível frustram ou, pelo menos, restringem a escolha de uma alimentação mais adequada e saudável. [...] Assim, as escolhas alimentares são determinadas não tanto pela preferência e pelos hábitos, mas muito mais pelo sistema de produção e abastecimento de alimentos (BRASIL, 2006, p. 24-5).

Em nível coletivo, constata-se a responsabilidade do Estado em fomentar as mudanças socioambientais, por meio de suas políticas públicas. Estas, por sua vez, visam que a promoção da alimentação saudável possibilite uma autonomia decisória dos indivíduos e 
grupos, para que possam ter informações suficientes em prol de suas escolhas alimentares. Em contrapartida, o Guia considera que proibições e limitações alimentares devem ser evitadas: "supervalorizar ou mistificar determinados alimentos em função de suas características nutricionais ou funcionais não deve constituir a prática da alimentação saudável” (BRASIL, 2006, p. 24).

Já o final da primeira parte destaca quais os modos de vida considerados saudáveis, divididos em duas dimensões, que são: estimular e incentivar práticas para saúde, como alimentação saudável, aleitamento materno e atividade física; inibir hábitos e práticas prejudiciais à saúde, como o uso do tabaco e álcool (BRASIL, 2006, p. 21).

Na parte 2, “O Guia Alimentar para a população brasileira: seus princípios e suas diretrizes e os atributos da alimentação saudável”, fornece o conjunto de recomendações dietéticas da Organização Mundial da Saúde (1998), em consonância com diretrizes específicas à realidade brasileira. Os seguintes princípios são elencados (BRASIL, 2006, grifo nosso):

- O princípio da abordagem integrada: enfatiza que os programas brasileiros de nutrição não devem se restringir à prevenção e ao controle das DCNT, mas, também, incluir uma abordagem de promoção da alimentação saudável, bem como adoção de modos de vida saudáveis.

- O princípio do referencial científico e a cultura alimentar: com base no estudo de práticas alimentares de culturas consolidadas, bem como no consenso científico, foi possível detectar que práticas de alimentação para a saúde se baseiam em uma grande variedade de alimentos de origem vegetal.

- O princípio do referencial positivo: enfatizam-se as vantagens de uma refeição saudável, em que o importante é estimular o consumo de certos alimentos, e não proibir o de outros.

- O princípio da explicitação de quantidades/ O princípio das variações das quantidades: é importante identificar quantidades e limites de consumo ou número de porções dos alimentos.

- O princípio do alimento como referência: é a adoção do alimento como referência nutricional, e não somente seus nutrientes. Isso porque, de acordo com evidências científicas, a relação de dietas com as doenças é expressa mais em termos de alimentos do que de componentes dietéticos específicos. (...) Além disso, diretrizes alimentares baseadas em alimentos são facilmente compreendidas por todas as pessoas.

- O princípio da sustentabilidade ambiental: incentivo ao consumo de alimentos naturais e produzidos localmente, valorizando os alimentos regionais, a produção familiar e a cultura alimentar. Valoriza também a produção de alimentos com o uso de recursos ambientalmente sustentáveis.

- O princípio da originalidade - um guia brasileiro: propõe um guia baseado nas necessidades da população brasileira, levando em conta seus alimentos e fundamentado em sua cultura alimentar.

- O princípio da abordagem multifocal: as recomendações são direcionadas o público, em geral, assim como setores específicos, como governo ou as indústrias. 
Em seguida aos princípios, o Guia fornece os atributos para a alimentação saudável, cujo destaque é a valorização da autonomia das pessoas na escolha dos alimentos (BRASIL, 2006, p. 32),

desde que o direito à informação esteja garantido; o resgate das práticas e dos hábitos regionais brasileiros, apostando em um movimento oposto à globalização valorização das práticas e dos hábitos regionais, um movimento oposto à globalização das dietas e descaracterização das culturas alimentares mundiais.

Outro ponto trazido à tona é a questão da acessibilidade física e financeira. Neste atributo, o Guia critica a atuação da mídia e da informação equivocada a respeito de uma alimentação saudável. Isso porque os autores do documento consideram que “[...] a alimentação saudável não é cara, pois se baseia em alimentos in natura e produzidos regionalmente” (BRASIL, 2006, p. 35). Quanto ao sabor dos alimentos, dar privilégio aos alimentos naturais e menos refinados, em detrimento de alimentos industrializados, que são divulgados, sobretudo por práticas de marketing.

As práticas de marketing são consideradas de responsabilidade do governo e do setor produtivo, visto que é o Estado quem deve regulamentar as estratégias dos produtores de alimentos, “[...] em todas as formas de mídia, principalmente aquelas direcionadas para crianças e adolescentes” (BRASIL, 2006). Em contrapartida, o Guia valoriza os sistemas alimentares que disponibilizam alimentos variados de origem vegetal, somados aos tipos mais saudáveis de alimentos de origem animal, e que têm como base a cultura alimentar nacional e regional. Esses sistemas "são de importância fundamental para a saúde pública, para a segurança alimentar e nutricional e para a soberania de um país” (BRASIL, 2006, p. 42).

Ao final de suas páginas, o Guia elenca as bases epidemiológicas e científicas das diretrizes nacionais, em que é possível observar suas referências e posicionamentos políticos. Pode-se notar, por exemplo, que suas orientações são baseadas em conhecimento científico, desenvolvido pela Organização das Nações Unidas e por outras agências internacionais, bem como pelo Ministério da Saúde de diversos países (BRASIL, 2006).

O Guia também reitera que o problema alimentar no Brasil, sobretudo o acesso ao alimento, se dá pelas desigualdades sociais, e não pela indisponibilidade, pois “[...] os alimentos produzidos no País são suficientes para alimentar toda a população” (BRASIL, 2006, p. 128). O Guia afirma que, no Brasil, a insegurança alimentar e nutricional se manifesta de maneiras diferentes em todos os estratos sociais e econômicos da população. No entanto, esse Guia considera que fazer parte da população que integra os estratos de renda mais alta não significa necessariamente boa nutrição, mostrando uma urgência governamental 
em implementar políticas públicas para garantir a segurança alimentar e nutricional a todos, baseada no incentivo à alimentação saudável e nas informações evidenciadas.

Pode-se notar que o Guia vem à tona como uma estratégia em SAN, que visa atender as demandas da população brasileira com relação às mudanças em sua cultura alimentar, trazendo maior esclarecimento e um posicionamento político do tema. Já no caso específico dos aspectos políticos, bem como a mídia que trata de alimentação, será adotado como fonte principal o jornalista Pollan (2007, 2008, 2010), conforme será mostrado no próximo tópico.

\subsection{Mídia e Alimentação: dilemas da dieta ocidental}

No contexto específico da alimentação e comunicação, o jornalista Pollan (2007, 2008, 2010) é especializado no assunto e retrata paradoxos midiáticos e políticos que cerceiam o tema. Pollan (2007) faz uma denúncia sobre a produção de alimentos de maneira industrial - insustentável para todas as cadeias que compõem a produção alimentar. Pollan (2008) mostra ainda a trajetória da alimentação ocidental - e suas consequências à saúde sob um olhar histórico e político. E por fim, Pollan (2010) apresenta o resumo das duas obras.

Outros autores que se destacam nesse assunto são Jacobson e Nestle (2000), que elaboraram diretrizes para a elaboração de políticas públicas em alimentação. Assim, Jacobson e Nestle (2000), considerados ativistas do assunto, reiteram o pensamento de Pollan (2007, 2008, 2010), a respeito da inadequação das tradicionais maneiras de prevenir e combater o sobrepeso e a obesidade, cujo foco é mudar o comportamento individual. Em vez dessa abordagem, os autores reforçam a necessidade de políticas públicas multifacetadas, assim como de substanciais financiamentos governamentais.

Como considerações iniciais sobre a abordagem midiática em alimentação, pode-se afirmar que o foco reside na culpabilização do indivíduo quanto ao seu sobrepeso ou deficiência alimentar. Essa culpabilização conta sempre com aval científico, sendo um dos aspectos da ideologia intitulada nutricionismo. O nutricionismo, que começou nos Estados Unidos no século XIX, e foi adotado como a ideologia oficial da dieta ocidental, consiste em definir se um alimento é bom ou mau conforme os nutrientes, tendo suas raízes no enfoque científico do alimento.

Assim, da mesma forma que uma descoberta científica se modifica a cada estudo, os bons e maus nutrientes se alternam num ciclo infindável, gerando mais confusão entre os indivíduos. Estes, por fim, terminam sem saber como proceder diante de um ato instintivo alimentar-se. O paradoxo é que, antes da alimentação moderna e do surgimento do 
nutricionismo, as pessoas contavam com a orientação de suas culturas étnicas ou regionais, parâmetros que não favorecem os grandes produtores de alimentos e as cadeias de fast-food (POLLAN, 2008, p. 146).

Pollan (2008, p. 95) responsabiliza a indústria alimentícia, o jornalismo e o governo pela disseminação dessa ideologia: os três ajudaram a amplificar o nutricionismo, na medida em que a indústria alimentícia anunciava seus produtos com teor nutricional duvidoso, mas com aparência de comida; o jornalismo divulga, acriticamente, as últimas descobertas alimentares; e o governo faz as recomendações oficiais, de maneira vaga, atendendo a diversas pressões políticas e com base em preceitos científicos vagos.

No que tange ao contexto nacional, muito do discurso sobre alimentação na mídia se deu pela influência do nutricionismo dos Estados Unidos. Ainda que as obras de Pollan (2007, 2008, 2010) abordem basicamente a problemática da dieta norte-americana, sabe-se que muitos desses hábitos alimentares foram incorporados à dieta brasileira, sobretudo em ambientes urbanos. E, hoje, arca-se com as mesmas consequências da maior economia do mundo - aumento substancial de obesos e das doenças crônicas não degenerativas em decorrência da má alimentação.

É diante desse cenário que Pollan (2007) falará sobre as matrizes da dieta ocidental, cujo advento se deu pela ansiedade em torno do alimento: é o Dilema do Onívoro. Em seguida, tratará em profundidade sobre o nutricionismo, a ideologia com raízes nos Estados Unidos e que, hoje, se espalhou pelo globo. Por fim, Jacobsen e Nestle (2000) darão um panorama da alimentação, fornecendo ideias de políticas públicas.

\subsubsection{Cultura alimentar e comida processada}

As publicações editoriais, além de divulgarem acriticamente as dietas da moda, também tentam compreender o suposto paradoxo de certas culturas alimentares, como a japonesa, a francesa e a mediterrânea. Para tanto, publicam diversas obras e artigos a fim de tentar explicar e extrair regras de uma alimentação que é calcada pela cultura, tradição - e, por que não - pelo prazer. Contudo, trata-se pouco sobre o paradoxo norte-americano, cujo povo tipicamente pouco saudável é obcecado em adquirir hábitos alimentares saudáveis. E é disso que trata a obra de Pollan (2007).

O autor acredita que uma mudança “tão violenta” na cultura dos hábitos alimentares é indício de uma “desordem alimentar nacional”, e tal desordem não aconteceria em uma 
cultura com tradições profundamente enraizadas no que diz respeito à comida e à alimentação (POLLAN, 2007, p. 10). Partindo desse pressuposto, um país com uma cultura alimentar estável não se renderia às “charlatanices” de um novo livro sobre dietas publicado a cada mês, tampouco seria suscetível “[...] às oscilações do pêndulo com o pânico e os modismos associados a certos alimentos” (POLLAN, 2007, p. 11).

Em um primeiro momento, a ansiedade em torno do alimento se dá pela diversidade de opções alimentares, ou seja, pelo fato de o ser humano conseguir comer quase qualquer coisa que a natureza tem a oferecer. Tal possibilidade assusta, sobretudo quando se descobre “que algumas das comidas à nossa disposição têm a capacidade de nos fazer adoecer ou nos matar” (POLLAN, 2007, p. 11). Essa ansiedade recebeu a alcunha de 'O Dilema do Onívoro', termo detectado pelo psicólogo e pesquisador Paul Rozin e que acaba se revelando um “[...] instrumento particularmente eficaz para compreender nossa difícil situação atual com relação à comida” (POLLAN, 2007, p. 11).

No caso específico dos Estados Unidos, Pollan (2007, p. 13) salienta que o dilema se torna ainda mais perceptível porque é uma nação relativamente nova, resultado de muitas populações diferentes de imigrantes. E, como cada uma delas possui tradição própria em relação à comida, os norte-americanos nunca contaram com uma única, forte e estável tradição culinária que os guiasse.

A falta de uma cultura alimentar estável predispõe a uma vulnerabilidade quanto às especulações do cientista, do jornalista de nutrição e do marqueteiro especializado em comida, setores em que o dilema do onívoro não é visto como dilema, mas como oportunidade. Afinal, "interessa muito à indústria de alimentos que nossas ansiedades a respeito sejam exacerbadas; assim, ela pode aliviá-la com novos produtos” (POLLAN, 2007, p. 13).

Dessa maneira, a indústria detectou a oportunidade de criar uma quantidade infinita de novos produtos, que, muitas vezes, não são muito diferentes entre si: é a comida industrial ou processada. A comida produzida em escala industrial representa a atual revolução alimentar, pois viabilizou a reinvenção da cadeia alimentícia destinada aos seres humanos. Entretanto, ainda não é possível saber as consequências para a saúde das pessoas e do ecossistema.

O autor ressalta não ser contrário ao processamento dos alimentos, sobretudo quando retoma o objetivo inicial da prática, que era libertar o homem dos ciclos da natureza. Nesse sentido, o ser humano começou a salgar, defumar, secar, fazer conservas; em seguida, passou a enlatar e embalar a vácuo. Porém, a vontade de libertar o homem da natureza começou a crescer e, com o fim da Segunda Guerra, o objetivo passou a aprimorar a natureza. Dessa 
forma, o foco do século XX se tornou uma combinação entre tecnologia, comodidade e esforços de marketing para pôr de lado a manteiga em prol da margarina, substituir o suco natural por bebidas à base de fruta, entre outras mudanças (POLLAN, 2007, p. 103).

O processamento de alimentos trouxe a lógica industrial para as mesas das pessoas, gerando obscuridade em sua produção. Isso viabilizou também uma mudança de padrões em relação aos alimentos, ou seja, uma alienação quanto à lógica de produção da comida. A lógica industrial permitiu o colapso do sistema alimentar norte-americano, em que são valorizadas "a regularidade, a mecanização, a previsibilidade, a permutabilidade e a economia de escala” (POLLAN, 2007, p. 218).

Um dos principais motivos para que essa obscuridade se concretize foi a modificação do uso dos termos para designar comida. Na década de 1960, os marqueteiros perceberam que o termo “comida processada” não venderia a imagem adequada de seus produtos. Com isso, o termo foi substituído por “ciência alimentar”, que passa uma imagem mais glamorosa e high-tech. A mudança nos termos possibilitou a remoção da ideia de processamento, menos palatável para a indústria alimentícia, que também se aproveitou da nova possibilidade para que a indústria acrescentasse, à vida útil dos alimentos, meses, até mesmo anos à sua existência nas prateleiras. O fato permitiu que o marketing fosse desenvolvido "em termos globais” (POLLAN, 2007, p. 107).

Além da mudança de termos, a cadeia por trás do alimento ficou ainda mais complicada e obscura com os rótulos e ingredientes impossíveis de se compreender. Para complementar, a informação sobre comida começou a focar somente em seu preço e quantidade - uma obscuridade que completa o ciclo em que o cidadão só se interessa pelo preço e, o produtor, só se importa com a produtividade.

Como contraponto a essa cadeia industrial, surge a cadeia alimentar pastoral ou orgânica. A cadeia alimentar pastoral explicita o longo caminho que existe até o alimento chegar às mesas das pessoas, tornando o processo de se alimentar mais consciente. Na opinião de Pollan (2007), essa cadeia pode ser considerada até mesmo pós-industrial. Porém, até mesmo a cadeia alimentar orgânica vem passando por um processo de industrialização, tornando-se semelhante ao movimento que pretendia contrapor. Esse processo, tal qual seu contraponto, o fast food, será explicado detalhadamente no tópico a seguir.

\subsubsection{Nação fast food versus Orgânicos: qual a real diferença?}


Antes de falar sobre produtos orgânicos, é necessário definir seu o extremo oposto: as cadeias de fast food. Estas representam a relação metafórica entre produtos industrializados e comida: sua velocidade do consumo e produção se dá porque não é possível saborear o produto, visto que, quanto mais a pessoa se concentrar em seu gosto, mais ela se dará conta de que não tem gosto algum (POLLAN, 2007). O fast food também obscurece a seguinte questão: “De onde vem a comida que estou comendo?” A resposta correta não é "Do McDonald's”, mas sim de frigoríficos, matadouros, armazéns, fazendas industriais, laboratórios de tecnologia, fabricantes de condimentos, refinarias de petróleo, fábricas de processamento, silos e, no fim, de um campo de soja e milho.

Em oposição ao termo fast food, o termo “orgânico” foi escolhido pelo jornalista J. I. Rodale, editor e fundador da Organic Gardening and Farming Magazine, para dar a entender que “[...] a natureza e não a máquina deveria oferecer um modelo adequado à agricultura” (POLLAN, 2007, p. 145). A palavra 'orgânico' trazia à tona a ideia de tudo o que a indústria não era. E, na contracultura de 1969, comer organicamente "era um ato que unia o pessoal ao político” (POLLAN, 2007, p. 158), visto que o movimento pregava o modo alternativo de produção e um sistema alternativo de consumo. Partindo desses princípios, "o que você comia era inseparável de como aquele produto era cultivado e como chegava até a sua mesa” (POLLAN, 2007, p. 158).

A complexidade do comer orgânico antagoniza com a visão da ciência, cuja premissa é quebrar sistemas complexos da natureza para entender seu funcionamento, trabalhando uma variável de cada vez. Além disso, uma das principais inovações dos alimentos orgânicos foi a possibilidade de criar um canal de informação entre o produtor e o consumidor. Contudo, o autor reitera que o rótulo orgânico “[...] pode evocar a imagem de uma agricultura mais simples, mas sua própria existência é um produto da indústria” (POLLAN, 2007, p. 152). Há uma contradição existente segundo Pollan (2007), principalmente nos setores da indústria que se apropriam do termo orgânico, que é aquela entre a industrialização do setor dos alimentos orgânicos da qual a rede faz parte e os ideais pastorais sobre os quais esse setor foi erguido.

Essa contradição fez com o que o longo caminho percorrido pelo movimento, que já data mais de 30 anos, atualmente se pareça muito mais como "um grande negócio do que com um movimento” (POLLAN, 2007, p. 153). Mesmo assim, não considera que o setor orgânico industrial seja necessariamente ruim, não se a meta for reformar um sistema alimentar de meio trilhão de dólares baseado nas redes de supermercados e nas expectativas do consumidor de que a comida seja prática e barata. Todavia, o autor desconfia de quando chegará o 
momento em que o estilo “[...] Pastoral Supermercado será mais uma mentira contada pelos marqueteiros” (POLLAN, 2007, p. 153).

Essa crítica se dá porque a existência das fazendas orgânicas industriais. Pollan (2007, p. 145) centra na ideia de vender produtos com aparência orgânica, mas feita com os mesmos objetivos de uma cadeia industrial. A agricultura orgânica atual, após ser absorvida nos mercado e tornar-se bem-sucedida, "foi ficando cada vez mais parecida com o sistema industrial que originalmente se propunha a substituir” (POLLAN, 2007, p. 166). O autor ainda destaca que o sentido da palavra orgânico foi "estendido e distorcido para permitir as mesmas práticas industriais às quais no passado ela se apresentava como uma crítica e uma alternativa” (POLLAN, 2007, p. 173).

Além do fast food, o autor elenca as seguintes causas para a obesidade e aumento de peso (POLLAN, 2007, p. 115, grifos do autor):

1) Mudança de estilo de vida: come-se mais e tornam-se mais sedentários;

2) Prosperidade: um número maior de pessoas pode pagar por uma dieta no estilo ocidental, ou seja, com alto índice de gordura;

3) Pobreza: "comidas saudáveis com alimentos não processados são mais caros";

4) Tecnologia: "poucos de nós usamos nossos corpos no nosso trabalho; em casa, o controle remoto nos mantém grudados no sofá";

5) Marketing inteligente: "porções gigantes; publicidade voltada para as crianças”;

6) Mudanças na dieta: "mais gorduras; mais carboidratos; mais alimentos processados.”.

As explicações acima são, em certa medida, verdadeiras. No entanto, para Pollan (2007), a causa central é: quando a comida é abundante e barata, as pessoas comerão mais dela e se tornarão obesas.

Outro ponto é a ausência de discussão política quando se trata do preço da comida (POLLAN, 2007, p. 116), trazendo uma contradição que se resume da seguinte maneira: enquanto o governo soa o alarme dizendo que a obesidade já é uma epidemia, o presidente assina leis de políticas agrícolas concebidas em prol do agronegócio. O mesmo governo que anuncia o combate à obesidade subsidia “[...] um rio de milho barato, garantindo que as calorias mais baratas do supermercado continuem a ser também as menos saudáveis” (POLLAN, 2007, p. 121).

\subsubsection{Alimentação: como mudar o cenário atual}

O cenário alarmante não foi o suficiente para ações efetivas, principalmente porque é possível se acostumar muito rapidamente a alguma coisa, sobretudo quando as pessoas ao 
redor não dão importância a ela (POLLAN, 2007, p. 250). Com o objetivo de propor alterações nas lógicas atuais de produção do alimento, o autor sugere as seguintes medidas:

- Mais transparência;

- Regulamentação da cadeia;

- Marketing do relacionamento na compra da comida, em que comprador e vendedor sabem quem faz parte da lógica de produção;

- Deixar de comer fast food para comer comida local;

- Comer comida orgânica, pagando mais por ela em prol de uma cadeia sustentável;

- Permitir que o pequeno produtor jogue em condições de igualdade com o grande produtor;

Quanto à questão de se pagar mais por uma comida de qualidade, Pollan (2007, p. 262) considera que, entre os norte-americanos há, sim, falta de prioridade em pagar mais por alimentos. O autor acredita que o barato sai caro e acha estranho que algo tão importante para a nossa saúde e bem-estar como comida seja frequentemente vendido apenas levando em conta o preço. Para Pollan (2008), quando se gasta mais com alimentação saudável, se gasta menos com saúde. Sugere também que as pessoas passem a produzir o próprio alimento, plantando uma horta, por exemplo. Isso porque, plantar o próprio alimento é um ato subversivo e um contraponto à indústria alimentícia, visto que, “[...] participar do intrincado e interminável processo de prover nosso sustento é a forma mais certa de escapar da cultura da fast-food e dos valores nela implícitos” (POLLAN, 2008, p. 203). Entre os valores do fast-food, destaca-se o de enxergar que a comida “deve ser rápida, barata e fácil; que o alimento é um produto da indústria, não da natureza; que comida é um combustível, não uma forma de comunhão com nossos semelhantes e com outras espécies - e com a natureza” (POLLAN, 2007, p. 212).

Além disso, o fato de o indivíduo não saber quem está na outra ponta da cadeia alimentar torna-se mote para que ele também não se importe com isso: o resultado é o descaso, tanto da parte dos produtores como dos consumidores, segundo Pollan (2007). Tal descaso é estimulado, visto que a economia global não funcionaria sem essa "[...] muralha de ignorância e indiferença que ela estimula” (POLLAN, 2007, p. 263). Em suma, uma visão do alimento como commodity viabiliza para este autor a estratégia de produzir ao menor custo possível.

Em contraposição a esse sistema, o autor sugere a produção artesanal, cuja estratégia competitiva está baseada “em vender algo especial em vez de ser apenas o produtor que vende uma determinada commodity a preços mais baixos” (POLLAN, 2007, p. 268). Porém, a ideia de vender algo excepcional e manter baixas suas despesas só funciona se esse modelo não 
imitar em nada o modelo industrial. A ressalva se dá porque o maior problema da agricultura alternativa, hoje, é o de que, frequentemente, há uma incorporação de elementos do modelo industrial e do modelo artesanal. Com isso, acaba descambando para um caminho "[...] que contém o pior dos dois modelos” (POLLAN, 2007, p. 268).

Já a medida de comprar diretamente com o produtor local é considerada um ato de civismo e até mesmo um protesto, sendo possível uma rebelião contra a lógica atual, começando do eixo da alimentação. Essa perspectiva se dá porque, talvez, a comida seja uma metáfora poderosa para um enorme número de valores que, na visão de muitas pessoas, “estão sendo ameaçados pela globalização, incluindo o caráter particular de identidades e culturas locais, a sobrevivência de paisagens locais e a biodiversidade” (POLLAN, 2007, p. 274).

Entre esses movimentos internacionais, o principal é o Slow Food, que surgiu na Itália em 1989 e pretende defender as tradições culinárias locais contra a maré mundial da homogeneização, para Pollan (2007). O Slow Food reconhece que a melhor maneira de combater a comida industrial é simplesmente fazer com que as pessoas se recordem do prazer de comer a comida tradicional.

Tal qual o Slow Food, Pollan (2007) defende a valorização do alimento local em contraposição ao orgânico. Isso porque o alimento orgânico está se adaptando cada vez mais aos modelos industriais, da mesma forma que o capitalismo se adaptou às outras tentativas de mudanças. Nesse sentido, a comida local pressupõe uma nova economia, assim como uma nova agricultura, novas relações econômicas, sociais e também ecológicas.

A defesa à comida local se dá porque a mesma, embora não signifique orgânica ou autossustentável, possui algumas características que a diferem de outro tipo de produção. Um exemplo é o de que seja menos provável que se apoie na monocultura, já que “[...] um fazendeiro que vise à produção local precisará investir em uma variedade de produtos em vez de investir somente em uma variedade de planta ou animal” (POLLAN, 2007, p. 277).

Quanto ao fast food, Pollan (2007) acredita que a ideia não é combatê-lo, mas mostrar que existem outros caminhos, garantindo alternativas que existam e prosperem. A comparação do fast food com o Slow Food permite enxergar duas refeições, que ocupam extremos opostos do espectro da alimentação humana, ou seja, “[...] das diferentes formas que temos de nos relacionar com o mundo que nos sustenta” (POLLAN, 2007, p. 434). Enquanto que os prazeres de uma refeição são baseados num conhecimento quase completo, os prazeres da outra se dão por uma completa ignorância. 
Pollan (2007) se mostra contrário aos dois extremos, visto que qualquer cientista social sério deve descartar uma vida regrada ao Slow Food ou fast food, já que são, para ele, desvios em relação à vida real.

Essas e outras afirmações polêmicas em torno da obra de Pollan (2007) não podem deixar de retomar seu principal objetivo, que é o de explicitar o longo e obscuro caminho que um alimento percorre da fazenda até as nossas mesas, cujo sistema atual insiste em esconder, para não revelar atrocidades cometidas. Tais processos são ocultos por uma cortina de complexidade econômica que atinge proporções globais.

Diante do "Dilema do Onívoro" e da ansiedade gerada pela questão de "o que comer?”, muitos charlatães, empresas e a mídia se aproveitam de tal vulnerabilidade para criar os modismos alimentares. Em última instância, Pollan (2007) reafirma que tal angústia se dá pela falta de tradições culinárias sólidas. Além disso, os norte-americanos se espantam de saber que algumas culturas traçam seus rumos pelo prazer e pelos hábitos, em lugar da culinária nutricional e do marketing, sendo que essas trajetórias os deixaram mais saudáveis do que a dieta dos Estados Unidos.

Pollan (2010, p. 12) afirma não haver nenhuma dieta humana ideal, visto que o ser humano é adaptado a uma ampla gama de alimentos e dietas, “com exceção de uma: a dieta ocidental, que a maioria de nós segue hoje.” Ele também reafirma não se contrapor à ciência, porque se valeu dela para criar os livros sobre comida. Contudo, se diz cético quando se trata da ciência nutricional e da mídia que a acompanha, uma vez que "há outras fontes de sabedoria no mundo e outros vocabulários de acordo com os quais é possível falar de modo inteligente sobre comida” (POLLAN, 2010, p. 15). O autor afirma que os seres humanos passaram milênios comendo bem e mantendo-se saudáveis “[...] antes que a ciência nutricional aparecesse para nos dizer como fazer isso; é totalmente possível comer de forma saudável sem saber o que é um antioxidante” (POLLAN, 2010, p. 15).

O autor ainda afirma que comer é um ato agrícola, ecológico e político. Mesmo assim, essa visão é obscurecida pelo paradigma atualmente vivido: a força do nutricionismo, cuja explicação detalhada se dará a seguir.

\subsubsection{Nutricionismo: a ideologia da dieta ocidental}

A dinâmica do nutricionismo funciona pela lógica da ciência e da novidade: afinal, deixar o ser humano se alimentar sem a orientação profissional - algo que o homem fez com 
extraordinário sucesso desde que desceu das árvores - "não é lucrativo para os nutricionistas, empresas do ramo da alimentação, [...] e simplesmente um tédio para um redator ou repórter de jornal” (POLLAN, 2008, p. 14).

O surgimento do nutricionismo, no século XIX, nos Estados Unidos, reflete a disseminação da dieta norte-americana e é uma maneira de deixar as pessoas cada vez mais doentes e gordas, conforme anota Pollan (2008); e, para piorar, esse tipo de dieta está se tornando a dieta mundial. A crítica à forma científica de encarar o alimento não é para eliminar a importância da ciência dos alimentos, mas para se ter em mente que "temos muito, se não mais, a aprender sobre alimentação com a história, a cultura e a tradição” (POLLAN, 2008, p. 20).

Pollan (2008) pontua que a ideia central do nutricionismo - que não é sinônimo de nutrição - é a de que os alimentos são, em essência, a soma de seus nutrientes. E como tantas ideologias, o nutricionismo depende “[...] de 'uma forma de dualismo', em que existe 'um nutriente mau para os partidários condenarem e um salvador bom para beatificarem'” (POLLAN, 2008, p. 38, grifos do autor). Visto que a visão nutricionista procura voltar-se somente ao nutriente, e não ao alimento, “[...] mesmo os alimentos processados poderão ser considerados 'mais saudáveis' para você do que os alimentos naturais se contiverem as quantidades apropriadas de alguns nutrientes” (POLLAN, 2008, p. 39). Esta prerrogativa viabiliza justificar a existência dos alimentos processados, deixando implícito que todos os alimentos de imitação poderão ser mais nutritivos que os verdadeiros.

O nutricionismo tende a criar muita ansiedade em torno da experiência de comprar e ingerir os alimentos, para Pollan (2008). Esse ato aparentemente simples agora deve estar acompanhado das últimas pesquisas científicas, estudo de rótulos cada vez maiores e confusos, bem como selecionar as alegações nutricionais ambíguas e, quem sabe, “[...] tentar curtir alimentos que foram modificados tendo em vista muitos outros objetivos além de simplesmente ser gostoso.” (POLLAN, 2008, p. 41).

Outra característica é atribuir os problemas de saúde dos indivíduos às opções de estilo de vida, “[...] deixando implícito que o indivíduo é responsável por qualquer doença que o acometa” (POLLAN, 2008, p. 84). Todavia, um fator muito mais poderoso do que a dieta ou o exercício para detecção de doenças é, no fim, a classe social. A dieta ocidental reflete um conjunto de mudanças radicais ao longo dos últimos 150 anos, “[...] não só em nossos alimentos, mas também em nossas relações alimentares, do solo até a refeição” (POLLAN, 2008, p. 121). Essa dieta, que corresponde à industrialização da alimentação e está sistemática e deliberadamente minando as culturas alimentares tradicionais em toda parte, 
segundo Pollan (2008). Isso porque, antes da alimentação moderna e do surgimento do nutricionismo, as pessoas usavam parâmetros em suas culturas étnicas ou regionais.

O nutricionismo foi usado pela indústria alimentícia para vender mais alimentos processados e "nutricionalmente enriquecidos", cerceando ainda mais as culturas alimentares tradicionais, que são um empecilho para o fast food, para Pollan (2008). Com a propaganda e a informação desencontrada, “[...] a indústria amplifica muito as afirmações da ciência nutricional, e a corrompe ao patrocinar as pesquisas nutricionais de seu próprio interesse” (POLLAN, 2008, p. 148).

Esse tipo de alimentação trouxe consequências negativas para os indivíduos que, agora, tornam-se ansiosos por não conseguirem comer enquanto não tiverem o aval das autoridades científicas. Pollan (2008, p. 150) ainda denuncia que, em última instância, tal ideologia se trata de mais um reflexo de um sistema incrivelmente adaptável: o capitalismo. Esse sistema político/econômico enxerga a onda de doenças decorrentes da má alimentação como uma oportunidade de negócios: comprimidos para emagrecer, operações para colocação de pontes cardíacas, bombas de insulina, cirurgia bariátrica.

Outro ponto decorrente da dieta ocidental é a pandemia global das doenças crônicas não degenerativas, que "não envolve vírus, bactérias, nem micróbios e espécie alguma apenas um tipo de alimentação” (POLLAN, 2008, p. 150). Há um desafio pela frente: enxergar se a população reagirá, adotando acriticamente mais uma dieta divulgada na mídia, ou mudando a cultura alimentar e a economia. O autor acredita que a resposta a esse desafio será negativa, pois, "ao que tudo indica, é mais fácil, ou pelo menos mais lucrativo, transformar uma doença da civilização em estilo de vida do que mudar a alimentação da civilização” (POLLAN, 2008, p. 151).

A fim de reverter tal cenário, Pollan (2008) aconselha parar de comer a dieta ocidental, visto que, conforme o ciclo da indústria alimentícia é preciso teorias para poder reelaborar melhor os alimentos industrializados específicos. E uma nova teoria "significa uma nova linha de produtos, permitindo que a indústria continue afinando a dieta ocidental em vez de fazer qualquer mudança mais radical em seu modelo de negócio.” (POLLAN, 2008, p. 157). Também vale destacar que, como grande parte do problema da alimentação advém dos alimentos processados, o desafio não é se preocupar com os nutrientes, mas "simplesmente evitar qualquer alimento que tenha sido processado a ponto de ser mais o produto da indústria que da natureza” (POLLAN, 2008, p. 159).

As dietas tradicionais também constituem um contraponto à dieta ocidental, pois, “assim como os alimentos são mais que a soma de seus nutrientes, os padrões alimentares 
parecem ser mais que a soma dos alimentos que o compreendem” (POLLAN, 2008, p. 192). É relevante também a defesa da cultura alimentar, uma vez que, “[...] se um alimento é mais que a soma de seus nutrientes e uma dieta é mais do que a soma de seus alimentos, logo, uma cultura alimentar é mais que a soma de seus cardápios.” (POLLAN, 2008, p. 197). Nesse sentido, abrange também os modos, os hábitos alimentares e as regras tácitas que, juntos, determinam a relação de um povo com a comida e com a alimentação.

Em todas as suas obras, Pollan $(2007,2008,2010)$ explicita sua teoria, que é a valorização do alimento local, da cultura alimentar, fim do nutricionismo e, em última instância, uma mudança na lógica econômica atual. Já que a mídia é um reflexo também dessa lógica econômica, é importante o indivíduo ter sempre em mente tal questão, visto que, embora se encontre sob essa lógica, ela é passível de ser mudada, ou, ao menos, explicitada nas brechas e nos silêncios.

Partindo de princípios semelhantes aos do autor, Jacobson e Nestle (2000) focam o cenário atual em torno da comida, propondo políticas públicas, conforme será mostrado a seguir.

\subsection{Políticas públicas para alimentação saudável}

Jacobson e Nestle (2000) reforçam que as estratégias bem sucedidas envolvem elementos individuais e sociais. E, um dos problemas encontrados nas políticas públicas de combate à obesidade é o alto arsenal de material educativo e publicitário, porém poucas ações de implementação efetivas na questão.

Com isso, diante das alarmantes estatísticas de sobrepeso e obesidade, o foco recomendado é a prevenção das doenças decorrentes da má alimentação. Para tanto, é necessária uma abordagem de mudanças de hábitos alimentares individuais, mas, também, eliminar as barreiras do meio social que impedem escolhas saudáveis de alimentos e estilo de vida - medidas difíceis de serem alcançadas (JACOBSON; NESTLE, 2000, p. 12).

Para explicitar sua teoria, esses autores fornecem um panorama histórico das políticas públicas em alimentação nos Estados Unidos. Já em 1952, foram encontradas recomendações dietéticas no combate à obesidade, divulgadas pela “American Heart Association: Food for Your Heart”. Tais recomendações consistiam em, basicamente, na diminuição do número de calorias ingeridas, em consonância com o aumento de atividades físicas. Entretanto, essas diretrizes, que se focam no comportamento individual, mostram-se carentes não só de criatividade como também comprovadamente ineficazes diante do cenário atual. 
Em 1969, participantes da “White House Conference on Food, Nutrition, and Health”, recomendaram uma forte campanha midiática nacional a fim de reverter os índices de obesidade. Em contrapartida, o “Dietary Goals”, de 1977, forneceu o primeiro indicativo da existência de fatores sociais na ingestão de alimentos, como a propaganda televisiva, mas não fez nenhuma recomendação para o governo em relação à educação, à pesquisa e aos rótulos de alimentos (JACOBSON; NESTLE, 2000, p. 15).

Esse cenário mostra alguns avanços na área, mas pouca ação prática por parte do governo. Os autores consideram que os executores de políticas públicas devem entender que, quando o assunto é obesidade, o meio ambiente da sociedade norte-americana é tóxico. A toxidade se amplia pela força da indústria alimentícia e das cadeias de restaurantes: ambas gastam vasta quantidade de recursos em publicidade, fazendo com que as pessoas se identifiquem e sejam fiéis a elas. A fidelidade funciona, a contar pelos vastos investimentos: em 2000, a indústria alimentícia norte-americana gastou 11 bilhões de dólares anuais em publicidade, e outros 22 bilhões de dólares em incentivos promocionais, estandes em supermercados, entre outras promoções aos consumidores.

Para reverter tal situação, é fornecida uma série de diretrizes (JACOBSON; NESTLE, 2000, p. 21), compiladas a seguir:

1) Campanhas midiáticas que promovam hábitos alimentares saudáveis, visto que é a principal estratégia adotada por alimentos não saudáveis. Nesse sentido, é necessário fazer campanhas similares às adotadas pela indústria alimentícia, mas, para vender um estilo de vida que promova a saúde;

2) Desestimular assistir à televisão e às propagandas de junk food;

3) Promover atividades físicas;

4) Educar as crianças na promoção de hábitos saudáveis;

5) Ajustar os preços: diminuição do preço dos alimentos saudáveis e aumento dos que possuem altos níveis energéticos.

Outras recomendações são:

- Campanhas educacionais;

- Controle dos rótulos e propagandas de alimentos;

- Programas de assistência à alimentação saudável;

- Treinamento e tratamento em saúde;

- Transporte e desenvolvimento urbanos;

- Impostos sobre alimentos com alto valor calórico, bem como subsidiar alimentos com baixo valor energético, como frutas, legumes e verduras; 
- Desenvolvimento e implementação de políticas nacionais.

Os autores consideram que as campanhas antiobesidade, promovidas pelo setor privado, podem atuar como coadjuvantes. Porém, é papel do governo criar políticas públicas em larga escala no combate à obesidade. Contraditoriamente, a principal barreira na promoção de uma alimentação saudável é a falta de investimento governamental no assunto, bem como a ausência de uma abordagem intersetorial, com vários departamentos e ministérios do governo atuando em prol de um estilo de vida e alimentação mais saudáveis.

Nota-se o quanto Pollan (2007, 2008, 2010), Jacobson e Nestle (2000), bem como os demais autores e documentos estudados, reiteram o papel do Estado no fomento à alimentação saudável, bem como denunciam o papel da mídia no aumento da obesidade. O dilema alimentar está configurado, bem como possíveis soluções. Com base na compilação e estudo do panorama, a seguir, serão mostradas as diretrizes para abordar o tema.

\subsection{Diretrizes para alimentação}

No que tange à análise do tema central, antes de iniciá-la, é válido reforçar que a escolha das diretrizes se deu pelos seguintes critérios:

1) Frequência e destaque do assunto nos documentos estudados;

2) Verificação de referências, marcos e fontes adotadas pelos autores;

3) Relevância para a pesquisa.

Alicerçadas nos critérios acima, em seguida foram elencadas um total de 32 diretrizes, divididas em quatro temas centrais, cujas categorias se encontram a seguir:

Parte I: Alimentação: como fazer a nova abordagem? - fornece 16 Diretrizes práticas para a abordagem do tema;

Parte II: Significado dos termos e classificações das informações sobre alimentos levanta questionamentos e sugestões sobre quais termos utilizar e em quais contextos. Total de quatro Diretrizes.

Parte III: Comida e suas conexões com o meio ambiente - apresenta uma amplitude do assunto e intersetorialidade do tema. Total de quatro diretrizes.

Parte IV: Comida - uma questão cultural e política - mostra a relação entre comida, política e cultura. Total de 7 diretrizes. 
Optou-se pela adoção do termo "diretriz" porque a pesquisa acredita em condutas, e não em regras para se abordar o tema da alimentação. Regras limitam, cerceiam a autonomia do indivíduo; já a autonomia permite que lhes dê embasamento crítico para fazer as próprias escolhas, de acordo com sua realidade individual e social.

\section{Parte I: Alimentação: como fazer a nova abordagem?}

\section{1) Não atribuir somente a culpa individual pela situação alimentar}

As escolhas alimentares são determinadas não tanto pela preferência e pelos hábitos, mas muito mais pelo sistema de produção e de abastecimento de alimentos, bem como pelas condições econômicas. Há, de fato, uma influência biológica e de padrões alimentares adquiridos; porém, há igualmente uma influência atrelada a fatores externos, como condições socioeconômicas e do meio ambiente, o que traz o caráter de denúncia das condições de trabalho, saúde e econômicas das pessoas.

Ao identificar que a condição alimentar não é somente responsabilidade individual, amplia-se a possibilidade de os indivíduos agirem em prol de si mesmos e de sua comunidade, cobrando ações por parte do governo para coibir questões, que interfiram em sua saúde (ações de marketing para alimentação, propagandas, empresas que adulteram alimentos), bem como exigir alimentos saudáveis e acessíveis, subsidiados pelo governo, entre outras medidas.

\section{2) Encontrar as brechas na grande mídia para criar informações alternativas, próprias e locais...}

A ideia não é combater determinados tópicos, como o fast food, mas mostrar que existem outros caminhos, assim como garantir que alternativas existam e prosperem (POLLAN, 2007, p. 279). Um exemplo é divulgar movimentos alternativos e que pouco aparecem na grande mídia, como o 'Freeganismo', Projeto Educando com a Horta Escolar, entre outros.

\section{3) ....Não ser tão radical e não negar totalmente a grande mídia}

A abordagem não pode visar somente à crítica aos padrões atuais, mas também se valer de exemplos concretos para se repensar hábitos de produção e consumo. 


\section{4) Evitar evangelizar da mesma maneira que a mídia de nutrição/dieta}

A importância da informação sobre alimentação saudável implica em fornecer condutas para que as pessoas possam ter autonomia para tomar escolhas, sejam elas saudáveis ou não. Todavia, é obrigação do comunicador e do Estado informar a verdadeira procedência dos alimentos e as implicações tanto individuais como sociais para um alimento altamente processado.

\section{5) Ao propor novas práticas em alimentação, evitar o tom de denúncia}

Em contraposição ao tom de denúncia, vale dar sugestões para se enxergar a alimentação sob outros pontos de vista - com base na cultura, nos fatores políticos e sociais. Como recurso, recomenda-se usar o humor - inclusive quando tratar de algo mais sério, como, por exemplo, quando falar em mudanças no sistema de produção de alimentos. Este recurso foi amplamente adotado por Pollan (2008), sobretudo quando tratou do nutricionismo.

\section{6) Mencionar que a questão do alimento está inserida no âmbito político e econômico \\ O modelo econômico possui uma lógica de desenvolvimento levado às últimas} consequências. Para compreender essa dinâmica, recomenda-se trazer à tona conceitos como sustentabilidade, agroindústria, indústria alimentícia. Esse tratamento intersetorial viabiliza abordar a questão da saúde como um tema intrínseco às questões do solo, das plantas, dos animais e dos seres humanos (POLLAN, 2007).

\section{7) Evitar o nutricionismo quando for elaborar pautas}

Repensar no fetichismo com o uso da ciência como o único instrumento confiável para se lidar com a natureza (POLLAN, 2008). Não é porque foi publicado um estudo científico que a informação está correta e pode ser divulgada: cada estudo exige uma apuração. É importante pensar na questão ao se deparar com algum dado e/ou estudo encontrado em, por exemplo, revistas de dietas.

\section{8) Desconfiar de textos como "um estudo indicou que”...}

Basta comparar os textos que se percebe a contradição: um estudo fala que o chocolate faz bem; o outro, que pode te matar a qualquer momento. Além disso, quando for escrever sobre alimentação, a moderação é o tom, pois, mesmo que o estudo seja relevante para 
divulgação, cada indivíduo tem uma lógica própria. Uma divulgação inadequada, como “coma chocolate e emagreça”, pode adoecer um diabético com problemas de peso.

\section{9) Ao falar de algum alimento novo, em vez de fazer somente a divulgação, ensine-o a ler o rótulo}

Pollan (2008, p. 127) preconiza: ensine o indivíduo a ler rótulos, destrinchando os ingredientes sem floreios e termos científicos, difíceis de entender. O que significa cada um dos termos? Qual a porcentagem de milho em um salgadinho? E, dos ingredientes citados, que significa emulsificante, encontrado no rótulo do frango empanado? No exemplo citado, a resposta seria: Emulsificante significa impedir que a água e as gorduras se separem. Se o indivíduo sabe ler o rótulo, consegue identificar a reação de determinado alimento em seu organismo.

\section{0) Estimular o questionamento sobre a origem das coisas}

Em vez de instigar a pessoa a pensar “O que devo comer?”, trazer à tona a pergunta “O que estou comendo? E de onde isso veio?”. Se o indivíduo ou o comunicador não conseguirem conceber, provavelmente a comida é pouco saudável.

No longo prazo, tais mudanças obrigarão os produtores de alimentos a repensar suas condições de produção de alimentos em escala industrial.

\section{1) Comida e o preço - um debate político}

O preço da comida entra no debate político: o "barato sai caro”. Uma alimentação baseada em escolhas dadas apenas pelo preço pode trazer sérias consequências à saúde. Por outro lado, no Brasil, grande parte da população compromete uma alta porcentagem de sua renda com alimentos. Neste caso, é papel do Estado subsidiar uma alimentação saudável para estratos familiares de menor renda. No longo prazo, disponibilizar alimentos pouco nutritivos acarreta em DCNG, cujos custos altos serão também subsidiados pelo Estado.

Além disso, ao tratar do preço dos alimentos, apontar os demais custos relacionados à produção dos mesmos, isto é, os custos adicionais para a saúde, o meio ambiente e para o trabalhador.

\section{2) Tamanho é documento - tamanho das porções}

É importante incentivar a impopular diretriz para comer menos. A moderação alimentar assim como os tipos de alimentos ingeridos são elementos importantes à 
manutenção da saúde. Enquanto a comida for vista apenas como condição de consumo, isto é, mais por menos, tamanho de porções, o que vai prevalecer é o lema da quantidade em detrimento da qualidade. Além disso, a questão da quantidade é outro atributo do capitalismo: quanto mais, melhor, e tal condição pode ser posta em questão em prol da saúde individual e do meio ambiente.

Outro ponto de destaque é com relação ao autocontrole: as pessoas não param de comer quando se sentem cheias. A fome não funciona desse jeito. Isso porque pesquisadores descobriram que os seres humanos (e os animais), quando apresentados a porções grandes de comida, costumam comer 30\% a mais (POLLAN, 2007). Nesse sentido, a orientação é que os produtores diminuam as porções e, por consequência, o preço dos alimentos.

\section{3) Não às Proibições ou limitações alimentares}

De acordo com Brasil (2006), a supervalorização e/ou mistificação de certos alimentos em detrimento de outros, ressaltando somente as características nutricionais ou funcionais, não é uma prática que promove a alimentação saudável.

\section{4) Não às dietas da moda}

Os padrões estéticos exigem um padrão “da moda” muitas vezes irreal para grande parte da população. Com isso, são divulgadas “dietas milagrosas” para perda de peso, de forma acentuada e rápida (BRASIL, 2006, p. 24). Essas dietas da moda, na maioria das vezes, causam prejuízos à saúde, e não atendem aos requisitos exigidos de uma alimentação saudável para a manutenção do bem-estar.

\section{5) Para falar de alimentos: aprenda a cozinhar}

Um dos principais recursos para entender os alimentos é cozinhando e compreendendo a cultura gastronômica. Na prática, essa percepção possibilita uma produção de conteúdo mais investigativa, ao elaborar uma informação sobre o alimento: sua procedência, modos de distribuição, entre outros.

\section{6) Mostrar que é possível uma alimentação saudável no cotidiano}

Uma das principais estratégias de marketing de alimentos da indústria alimentícia é criar um vínculo sígnico/simbólico da pessoa com a marca. Tal procedimento não reverte necessariamente em consumo da marca, mas em uma identificação com um determinado 
estilo de vida, em que o consumidor toma tais comportamentos como "forma de manifestação de seus hábitos” (TRINDADE, 2012, p. 79), reforçando sua visão de mundo.

Nesse sentido, quando for falar de alimentação saudável, é positivo usar a mesma abordagem de vínculo da indústria, mas, para outro fim, que é o de estimular uma alimentação saudável, identificada com o cotidiano, por meio de alimentos acessíveis e locais. É válido trazer essa percepção, a fim de que o indivíduo questione e mude os pequenos hábitos no cotidiano.

\section{7) Questionar: a validade do alimento}

Para detectar o grande dilema da indústria alimentícia, uma das maneiras é fazer perguntas como: “é possível um frango valer por anos?”; “Por que o leite hoje é válido por tantos meses?”. Quando se questiona a validade, bem como os ingredientes dos alimentos, é levantada a longa e obscura cadeia da indústria alimentícia.

\section{Parte II: significado dos termos e classificações das informações sobre alimentos}

\section{8) Procure fontes midiáticas fora do Brasil - e da caixa}

Fontes de informações diferenciadas do discurso do nutricionismo podem ser encontradas em setores da saúde pública e de movimentos alinhados à Promoção da Saúde ${ }^{12}$. Além disso, estudar culturas alimentares de países com baixos índices de doenças relacionadas à dieta - como a mediterrânea, francesa, coreana ou japonesa - proporciona novas diretrizes que, por vezes, podem ser aplicadas à realidade nacional.

\section{9) Significado dos termos: saudável, orgânico, diet.}

A reflexão profunda sobre o que cada palavra significa (orgânico, sustentável, natural) enriquece os conteúdos sobre alimentação. A mídia e a indústria frequentemente atribuem significações a termos de acordo com seus interesses; por isso, é importante ficar atento aos termos e não os repetir somente porque alguma autoridade científica ou produto alimentício lançou tal termo.

\section{0) Classificação de termos 1: natural ou industrializado?}

\footnotetext{
${ }^{12}$ A definição mais aprofundada de "Promoção da Saúde” consta no Capítulo 5, “Comunicação e Saúde”.
} 
Diversos estudiosos vêm sugerindo esse tipo de classificação, que separa os alimentos entre naturais e industrializados. Essa divisão parte da prerrogativa de que o início da epidemia de obesidade coincide com o período em que os alimentos altamente processados passaram a compor uma parte grande da dieta das pessoas.

\section{1) Classificação de termos 2: integral ou processado?}

Quanto ao processamento dos alimentos, o Brasil (2006) criou uma escala composta por três grupos:

Grupo 1: frutas, verduras, legumes, grãos, carne, leite e ovos frescos, entre outros. Ou seja, se há apenas um ingrediente (por exemplo, banana, ovo), é um produto do grupo 1.

Grupo 2: reúne ingredientes culinários, isto é, alimentos que sofrem um processamento mais intenso - como refinar, moer ou extrair gorduras -, mas que não são consumidos por si só. É o caso das farinhas, óleos, massas e açúcar.

Grupo 3: são os alimentos ultraprocessados, equivalente a industrializados prontos ou semiprontos para consumo. Sua preparação é basicamente composta de produtos do Grupo 2, com pouca ou nenhuma participação do Grupo 1. Entram nessa categoria biscoitos, salgadinhos, refrigerantes, e também lanches de grandes redes de pizza e hambúrguer, que são apenas montados ou aquecidos no local. O recomendado é que a alimentação se baseie principalmente em alimentos do primeiro grupo, com elementos do segundo. Os ultraprocessados devem entrar em uma proporção mínima na dieta.

\section{Parte III: Comida e suas conexões com o meio ambiente}

\section{2) Comida e sustentabilidade}

Para trazer a conexão entre comida e sustentabilidade, é conveniente dar exemplos aplicáveis, como ensinar as pessoas a reaprenderem o que significa comer levando em conta as estações do ano (POLLAN, 2007). É importante também trazer conteúdos que tratem do reaproveitamento de alimentos - sem fazer alusão de que se trata de sinônimo de pobreza ou avareza.

\section{3) Alimentação mais verde}

Alimentação natural, variada e de origem vegetal: essa é basicamente a diretriz recomendada por todos os órgãos oficiais, como FAO, OMS e o 'Guia Alimentar para a 
População Brasileira’ (BRASIL, 2010). Esse tipo de alimentação contribui na proteção contra doenças, e é consenso científico em relação aos princípios de alimentação adequada, como ficou evidente nos anos de 1980 e foi consolidada nos anos de 1990 (BRASIL, 2006, p. 34). Tal reorientação de prioridades “[...] incentiva o delineamento de políticas para criar ou proteger sistemas alimentares baseados em uma grande variedade de alimentos de origem vegetal” (BRASIL, 2006, p. 34).

Há também consenso de que uma dieta rica em alimentos de origem vegetal é benéfica para a saúde, bem como permite que se desenvolvam e identifiquem formas efetivas de apoio a práticas sustentáveis de produção de alimentos.

\section{4) Comida e vegetarianismo: o que realmente importa?}

Ao tratar do vegetarianismo, em vez de limitar o discurso apenas a que tipo de alimentos comer e disponibilizar receitas, abordar também a seguinte questão: “a espécie do animal que comemos pode ser a ser menos importante do que aquilo que o próprio animal está comendo” (POLLAN, 2007, p. 288). Nesse sentido, o discurso sobre vegetarianismo pode se ater mais aos modos de produção de alimentos - seja de origem animal, seja vegetal - do que pelo alimento em si.

\section{5) Comer de forma consciente}

Informar sobre o comer consciente traz à tona a longa cadeia "cármica”, que fez o alimento chegar à mesa (POLLAN, 2007, p. 17). Vale incentivar não comer à maneira industrial - isto é, comer sem pensar no que está fazendo (POLLAN, 2007, p. 434). Alimentar-se com consciência, prestando atenção ao que se está comendo, também estimula a desconfiança em relação aos alimentos industrializados, que favorecem serem comidos sem prestar atenção. Tais alimentos normalmente são menos nutritivos e dados a comer de forma compulsiva. 


\section{Parte IV: Comida - uma questão cultural e política}

\section{6) SAN, DHAA, Soberania Alimentar: temas viáveis em todas as editorias}

Por serem temas complexos, a questão da Segurança Alimentar e Nutricional (SAN), bem como seus componentes, como o Direito Humano à Alimentação Adequada (DHAA) e a Soberania Alimentar, demandam uma abordagem mais aprofundada.

Vale acrescentar que, uma vez que a SAN implica em diversas interfaces, um dos pontos centrais que podem ser destacados é não só falar do acesso aos alimentos, mas também inserir a questão da realização do direito, dando a conotação da necessidade de intervenção política e social.

\section{7) Aspectos da insegurança alimentar: acesso e excesso}

A contemporaneidade vive dois dilemas: a pobreza, que é empecilho para acesso ao DHAA; e a obesidade, cuja questão é o tipo de acesso que se tem ao alimento. Portanto, vale destacar que tanto a fome quanto a obesidade são aspectos da insegurança alimentar e, no fim, da desigualdade social.

\section{8) Trabalhar com a questão do sistema alimentar}

O sistema alimentar traz à tona que o alimento corresponde a um conjunto profundamente influenciado pelas condições naturais como clima, solo, história, cultura, políticas e práticas econômicas e comerciais. Nesse sentido, é válido retratar como o alimento advém de um conjunto de processos que incluem agricultura, pecuária, produção, processamento, distribuição, importação e exportação, publicidade, abastecimento, comercialização, preparação e consumo de alimentos e bebidas (COSTA, 2011).

\section{9) Compreender a cultura alimentar do seu país, região, cidade}

Antes de divulgar um novo alimento “milagroso” e/ou importado, compreender se há sentido em inseri-lo na cultura do local em que o conteúdo está sendo produzido. Isso porque a alimentação e a saúde estão vinculadas também à questão do grupo, dos indivíduos e de seu ambiente; além disso, a maneira de viver do indivíduo apoia-se na cultura, nas crenças e nos valores compartilhados entre as pessoas. Dessa maneira, vale compreender não só os aspectos que envolvem a saúde dos indivíduos, mas também os hábitos e a cultura do local em que estão inseridos. 


\section{0) Pensar em padrões alimentares}

Em vez do termo "hábitos alimentares", o uso do termo padrões alimentares detecta uma visão ampliada da questão. O padrão alimentar de uma população resulta de uma cadeia de causas, que se inicia na produção e comercialização dos alimentos, passando para os parâmetros de transformação do alimento dentro das indústrias, e ao mercado publicitário e midiático, para Costa (2011).

No caso específico do Brasil, o padrão alimentar atual contribui para o aumento da obesidade e não estimula a alimentação saudável - pontos centrais que podem ser levados a debate ao informar sobre alimentação.

\section{1) Alimentação: assunto interdisciplinar}

Alimentação não concerne somente ao setor saúde, mas, sim, possui um espectro ampliado de áreas que envolvem a questão. Com isso, a alimentação deve ser vista sob a integração de outros setores e atores sociais - cientistas sociais, antropólogos, profissionais da saúde, jornalistas, entre outros.

\section{2) Alimentação saudável é um direito social}

Alimentação como direito social pressupõe a intervenção estatal, por meio de políticas públicas. Em nível coletivo, é também responsabilidade do Estado o incentivo de mudanças socioambientais, para favorecer as escolhas saudáveis em nível individual ou familiar.

\subsection{Alimentação: precisa ser um dilema?}

Com base nos autores estudados, nota-se que, no Brasil, já existe uma cultura alimentar, baseada em alimentos como arroz, feijão, vegetais e proteínas. No entanto, Araújo e Cardoso o cidadão se depara com tantas opções - advindas principalmente por influência norte-americana - que acaba se confundindo e esquecendo quais são as raízes de uma alimentação saudável.

Como contrapartida a esse dilema, o jornalista Pollan $(2007,2008,2010)$ traz à tona quanto o questionamento do tema alimento é intersetorial, político e, por consequência, de interesse público. $\mathrm{O}$ autor afirma que, apesar de chamar de regras, pensa nelas menos como leis fixas do que como políticas pessoais: “[...] políticas são instrumentos úteis. Em vez de receitar comportamentos altamente específicos, elas nos dão diretrizes amplas que deveriam facilitar e agilizar nossas tomadas de decisão no dia a dia.” (POLLAN, 2010, p. 18). 
Essas diretrizes não pretendem ser uma afronta à indústria alimentícia; pelo contrário, é um manifesto para que ela mude, antes que as consequências à natureza, às pessoas e - por que não - ao marketing da marca dessa indústria sejam irreversíveis. Além disso, quem vai transmitir a informação sobre o alimento, ao demonstrar conhecimento e senso crítico concernente ao assunto, conseguirá trazer outro nível de discussão e abordagem para qualquer assunto relativo à temática - seja o lançamento de um "novo” alimento, uma nova dieta, orgânicos, vegetarianismo, marketing e publicidade de alimentos, entre outros.

Em contrapartida, ainda que as considerações de Pollan (2007, 2008, 2010) sejam extremamente úteis ao trabalho, deve-se sempre trazer a questão para a realidade brasileira. Nesse sentido, no Brasil, existem muitos produtos processados, que são mais caros do que os alimentos in natura, sobretudo os vegetais e frutas. Contudo, o marketing bem como a falta de incentivo governamental e a divulgação dos veículos midiáticos fazem com que o indivíduo não saiba as questões implicadas em um produto artificial, devidamente embalado e à base e soja e milho.

Uma campanha forte, envolvendo governo e sociedade civil, em prol da alimentação saudável, traria à tona o incentivo ao pequeno produtor, à agricultura familiar, às hortas orgânicas e/ou urbanas - antes que se atinjam os patamares dos Estados Unidos, em que o natural é ser gordo, barato e rápido.

Ainda com relação às pontuações de Pollan (2007, 2008, 2010), uma de suas principais militâncias é a de que a comida não seja tão prática e barata. E, embora seja alinhada com os paradigmas atuais, aplicar essa proposição à realidade nacional não é viável, diante do fato de que milhões de lares brasileiros - cerca de 30\% da população - possui algum grau de insegurança alimentar, não tendo garantia de que terá a próxima refeição. Nesse sentido, os gastos dos brasileiros com alimentação são altos e não são baseados em decisões, mas, sim, nas possibilidades financeiras.

Por conta disso, uma proposta seria aumentar os preços de alimentos pouco nutritivos, subsidiando os alimentos in natura e produzidos segundo condições mais humanitárias e sustentáveis. Vale ressaltar que, embora no Brasil a questão da fome seja forte como a da obesidade, o problema maior é que há uma imitação da cultura fast food norte-americana. Ou seja, em nosso país, é possível ter uma alimentação mais diversificada e rica, mas que não é feita por falta de tempo, dinheiro e por modismos - mais um sintoma da alimentação em estilo industrial.

Já no caso específico dos Estados Unidos, Pollan (2007, p. 13) salienta que o dilema da alimentação atual se torna ainda mais perceptível porque é uma nação relativamente nova, 
resultado de muitas populações diferentes de imigrantes. E, como cada uma delas possui tradição própria em relação à comida, os norte-americanos nunca contaram com uma única, forte e estável tradição culinária que os guiasse. Por possuir trajetória semelhante, em grande parte do Brasil ocorreu influência similar à dos Estados Unidos, isto é, uma nação influenciada pelos ditames de cadeias de fast food e da comida industrializada.

Por fim, embora exista o tom de denúncia nas diretrizes, o que importa pensar a respeito do capitalismo e da indústria é que estes não se constituem em instituições estáticas, cujo único objetivo é que as pessoas sejam gordas e comam cada vez mais comida industrializada. Como parte de um sistema econômico, seu objetivo é vender o máximo possível, sem precisar customizar o produto de acordo com a cultura, e que as pessoas consumam o máximo que puderem. Ao pensar dessa maneira simplista, toda cultura fast food e incentivadora da obesidade é compreensível. Mas, quando o coletivo tem essa percepção e passa a exigir - tanto do Estado quando das empresas privadas - a maior regulamentação e valorização do produtor regional, local e a agricultura familiar, as instituições aparentemente imóveis terão que, efetivamente, mudar. 


\section{Material didático do Projeto Educando com a Horta Escolar}

A adoção do material didático do Projeto Educando com a Horta Escolar (PEHE) como objeto de estudo integra a opção por um material comunicativo diferenciado e com baixa visibilidade na grande mídia. Tal escolha se deu como uma maneira de conhecer, em profundidade, um projeto que propõe uma visão intersetorial da alimentação e que se apresenta como uma estratégia em Segurança Alimentar e Nutricional (SAN).

Com o objetivo de apresentar e aprofundar o objeto de estudo, o presente capítulo terá a seguinte estrutura:

- apresentação do objeto de pesquisa, o Projeto Educando com a Horta Escolar;

- descritivo do material didático feito para docentes, composto por três cadernos, dando destaque para os tópicos de interesse para o trabalho ${ }^{13}$;

- apreciação crítica do PEHE, com base na análise temática, iniciando-se pela leitura atenta e pela investigação de seu material didático.

\subsection{O Projeto Educando com a Horta Escolar}

O projeto transdisciplinar Educando com a Horta Escolar (PEHE) surgiu em 2005 e foi realizado pelo Fundo Nacional de Desenvolvimento da Educação (FNDE)/Programa Nacional de Alimentação Escolar (PNAE), em parceria com a Organização das Nações Unidas para a Agricultura e Alimentação (FAO). Nas escolas atendidas pelo PNAE, o projeto objetiva educar e promover, pela horta escolar, uma cultura alimentar de hábitos alimentares que promovam a saúde para crianças entre 6 e 14 anos, na qual alunos, docentes e a comunidade interagem e realizam sua própria cultura de legumes e hortaliças.

No primeiro momento, o PEHE aparenta ter, como objetivo principal, somente a execução da horta em ambiente escolar, prática adotada em ambientes educativos distintos. No entanto, há uma proposta transdisciplinar de educação para a cidadania, visto que coloca a horta como eixo gerador de outras discussões, por meio de material didático para professores e alunos e acompanhamento dos projetos por parte da organização e dos conselheiros do projeto. Além disso, é uma estratégia no enfrentamento dos desafios para garantir a segurança alimentar e nutricional no Brasil e no mundo, e, como política pública, o PEHE objetiva um fortalecimento da ação do Estado na questão da segurança alimentar e nutricional,

\footnotetext{
${ }^{13}$ Ultrapassa o propósito da presente pesquisa a análise detalhada de cada aspecto textual do material didático, sendo a apreciação crítica centrada na documentação e referências teóricas adotadas pelo PEHE.
} 
principalmente entre crianças e adolescentes (PROJETO EDUCANDO COM A HORTA ESCOLAR, 2010, p. 105).

Sua metodologia consiste na formação continuada dos membros envolvidos, na implantação da horta escolar, na implementação de projetos e currículos escolares que permitam visibilidade sobre conscientização da

sustentabilidade ambiental, na segurança alimentar e nutricional e no estímulo à adoção de mecanismos de compra direta de gêneros alimentícios da agricultura familiar local, em consonância com as diretrizes do Programa Nacional de Alimentação Escolar (PNAE)" (PROJETO EDUCANDO COM A HORTA ESCOLAR, 2010, p. 103).

O PEHE foi considerado com base nas diretrizes do PNAE e na Lei da Alimentação Escolar, de 2009. Entre as diretrizes do PNAE, destaca-se

a questão da universalidade; o respeito aos hábitos alimentares e à cultura alimentar local; a garantia da participação e do controle social; a garantia de uma alimentação saudável e adequada com cardápios variados, alimentos seguros, adequados às necessidades nutricionais de acordo com faixa etária, sexo, atividade física e estado de saúde, e que respeitem a cultura alimentar e o apoio ao desenvolvimento local sustentável, pela aquisição de alimentos diversificados, produzidos pela agricultura familiar e agroextrativista locais. (COSTA, 2011, p. 282).

Além disso, há um Projeto Político Pedagógico articulado ao PEHE, visto que a abordagem do projeto deve ser considerada dentro do ambiente escolar, como "[...] uma função transformadora e política” (PROJETO EDUCANDO COM A HORTA ESCOLAR, 2010, p. 80). Conforme o ambiente da horta propõem-se atividades que pretendem não só fornecer as propriedades nutricionais dos alimentos, mas também proporcionar aos escolares uma visão crítica sobre alimentação, dando maior autonomia e autoridade diante das escolhas cotidianas, como o consumo consciente, maior percepção sobre os efeitos da mídia e publicidade e sobre seus próprios padrões alimentares (PROJETO EDUCANDO COM A HORTA ESCOLAR, 2010, p. 103).

Baseado nas estratégias metodológicas e no aconselhamento técnico, fornecidos pela FAO, foi implementado o piloto TCP/BRA/3003 - “A horta escolar como eixo gerador de dinâmicas comunitárias, educação ambiental, alimentação saudável e sustentável”, em escolas públicas de três municípios brasileiros com baixos Índices de Desenvolvimento Humano (IDH): Santo Antônio do Descoberto (GO), Saubara (BA) e Bagé (RS) (PROJETO EDUCANDO COM A HORTA ESCOLAR, 2010).

Da experiência do projeto piloto, sucedeu a implementação como estratégia de política pública em segurança alimentar e nutricional em quatorze municípios - doze do Estado da 
Bahia e dois no Estado de Goiás, com resultados diversos, com destaque para os apontados a seguir:

1. Mudanças significativas nos hábitos alimentares dos escolares;

2. Adaptações substantivas dos cardápios às especificidades regionais, inclusive no que diz respeito à inclusão de hortaliças oriundas da produção de agricultores familiares na alimentação escolar;

3. Maior qualidade e quantidade de projetos ambientais;

4. Melhoria da qualidade do trabalho pedagógico das escolas e, consequentemente, melhor desempenho dos alunos no que se refere à aprendizagem. (PROJETO EDUCANDO COM A HORTA ESCOLAR, 2010, p. 8).

De 2005 a 2010, o projeto alcançou 77 municípios brasileiros, bem como alguns países da América Latina e Caribe, implantando hortas nas escolas, promovendo encontros pedagógicos, formação de professores e nutricionistas e acompanhamento continuado das atividades. A formação se dá por meio de cursos, palestras e oficinas, mas o projeto pretende que cada instituição escolar adapte as alternativas metodológicas a seu contexto social.

Utilizando-se a horta como eixo gerador de prática pedagógica, o projeto propõe a integração de três áreas principais: educação/currículo, alimentação/nutrição e meio ambiente / hortas escolares (PROJETO EDUCANDO COM A HORTA ESCOLAR, 2010) e traz, além do fortalecimento da cultura regional, a maior consciência de crianças e adolescentes sobre práticas de alimentação para promoção da saúde e sustentabilidade. Apoiado na educação, o PEHE também pretende se estender às famílias da criança, já que o que foi aprendido pode ser repassado ao ambiente familiar, com a possibilidade de mudanças ainda maiores na cultura alimentar, educacional e ambiental.

Com isso, propõe-se que a horta seja o catalisador de uma experiência multidisciplinar que envolva não só docentes e discentes como também toda a comunidade, iniciando-se com as atividades sugeridas nos cadernos do material didático. Os três cadernos para docentes e os dois cadernos para discentes ${ }^{14}$ "garantem o eixo conceitual e metodológico do projeto" (PROJETO EDUCANDO COM A HORTA ESCOLAR, 2010, p. 32) e, neles são elencados não só a execução da horta, mas também uma discussão em torno de temas como alimentação, saúde, meio ambiente, educação, com atividades intra e extraclasse.

Além do material didático, composto por cinco cadernos impressos em papel reciclado e encadernados em espiral, é também fornecido ao professor:

\footnotetext{
${ }^{14}$ Esses cadernos são divididos por faixa etária de 6 a 10 anos e de 11 a 14 anos.
} 
- dois CD-ROMs com entrevistas com os membros do Projeto, explicações metodológicas sobre a horta, depoimentos e material produzido por alunos e docentes das escolas participantes;

- um caderno impresso, em espiral, intitulado "Mapeamento do Projeto Educando com a Horta Escolar”, com informações sobre a execução do PEHE e os resultados alcançados.

No conteúdo do material didático, os docentes encontram sugestões de atividades intra e extraclasse que circundem a temática, como: análise de propagandas e rótulos de alimentos; exibição de filmes em sala de aula que abordem a temática da alimentação e saúde, propondo debates entre os alunos; elaboração de jornal da escola para falar de alimentação ${ }^{15}$, somando 29 sugestões.

O material didático do projeto voltado aos educadores é composto por três cadernos, que são:

Caderno 1 - A Horta Escolar dinamizando o currículo da escola: explanação sobre o contexto socioeconômico atual, sobre o projeto, bem como sugestões de atividades para a implantação da horta escolar;

Caderno 2 - Orientações para a implantação e implementação da horta escolar: conteúdo com técnicas e procedimentos para execução da horta - plantio, cuidados, cultivos, manutenção, técnicas e profissionais envolvidos, entre outros;

Caderno 3 - Alimentação e nutrição: caminhos para uma vida saudável: aborda a cultura alimentar em nosso país, fornece diretrizes para uma alimentação saudável e estratégias na compreensão da cultura alimentar do Brasil.

Vale ressaltar que, com base no material voltado para docentes, foram criadas duas cartilhas para os alunos e tais materiais possuem linguagens diferenciadas, de acordo com a faixa etária. Estes contêm uma versão simplificada e reduzida do material didático destinado ao professor. As cartilhas encontram-se divididas em:

Caderno 4 - Volume I: Aprendendo com a horta I: destinado a crianças de 6 a 10 anos;

Caderno 4 - Volume II: Aprendendo com a horta II: para a faixa etária de 11 a 14 anos.

Os materiais para docentes e discentes são vastamente ilustrados e fazem referências diversas a autores que abordam a temática da educação, principalmente Paulo Freire; inserem trechos de poesias e músicas relacionadas a temas como meio ambiente, comida e educação; citam matérias jornalísticas que tratam do tema, entre outras. A dinamicidade do PEHE se dá na abordagem não só da técnica da implantação da horta, como também por promover outras

\footnotetext{
${ }^{15}$ Para o presente estudo, destaque para as que usam os meios de comunicação como objeto de análise.
} 
reflexões a fim de que se obtenha uma inserção da horta no cotidiano dos alunos e de quem está em torno do ambiente escolar.

Em resumo, os três cadernos correspondem aos três eixos do Projeto, isto é:

- Educação/currículo - as temáticas se concentram no Caderno 1 e no "Mapeamento dos processos da área de Educação”;

- Meio ambiente/hortas escolares - concentram-se no Caderno 2 e no "Mapeamento dos processos da área de Ambiente/Hortas Escolares”;

- Alimentação/Nutrição - concentram-se no Caderno 3 e no "Mapeamento dos processos da área de Alimentação e Nutrição”.

O PEHE foi encerrado em setembro de $2010^{16}$ e, no final de 2011, o site oficial, que era o principal meio de divulgação e consulta de materiais, foi desativado ${ }^{17}$. Em janeiro de 2012, o projeto foi retomado com um novo nome: Educando com a Horta Escolar e a Gastronomia, no qual o Fundo Nacional de Desenvolvimento da Educação (FNDE) une-se ao Núcleo de Referência em Gastronomia e Alimentação Regional do Centro de Excelência em Turismo (CET-UnB) para revisar a metodologia e introduzir um novo enfoque: a gastronomia. Esta é adotada como instrumento de valorização dos ingredientes e receitas regionais, das técnicas culinárias de preparação dos alimentos e da integração dos alunos no preparo das refeições. Foram selecionados, via edital, 200 municípios no território nacional.

\subsection{PEHE: descritivo do material didático}

Após apresentar o Projeto Educando com a Horta Escolar (PEHE), no tópico a seguir serão delineados os temas presentes nos três cadernos para docentes que têm maior relevância para a pesquisa. No que concerne ao descritivo dos cadernos, optou-se por uma atenção distinta em cada material. E, por terem conteúdos mais relacionados ao trabalho, os Cadernos 1 - A Horta Escolar dinamizando o currículo da escola e Caderno 3 - Alimentação e nutrição: caminhos para uma vida saudável terão um descritivo mais detalhado do que o Caderno 2 - Orientações para implantação e implementação da horta escolar.

\footnotetext{
${ }^{16}$ Em troca de e-mails e telefonemas com os responsáveis pelo escritório da FAO no Brasil.

${ }^{17}$ O site oficial era o principal meio de divulgação e consulta de materiais, com possibilidade de baixar, gratuitamente, o material didático, mapeamento e resultados do projeto; o site também era fonte de notícias, possuía um blog com postagens dos alunos participantes, banco de imagens, entre outros.
} 


\subsubsection{Caderno 1 - A Horta Escolar dinamizando o currículo da escola}

\section{Páginas: 118}

\section{Capítulos: 9}

Objetivo: reflexão a respeito do papel social da escola e as questões abrangentes que envolvem os professores, bem como a abordagem de temáticas como meio ambiente, sustentabilidade e cidadania.

O Caderno 1 é mais voltado para que o professor reflita a respeito do papel social da escola e as questões abrangentes, que envolvem os professores (PROJETO EDUCANDO COM A HORTA ESCOLAR, 2010, p. 45). Logo na “Apresentação”, propõe seu objetivo, que é uma mudança na cultura alimentar, focando nas crianças, posto que ainda estejam formando suas opiniões em torno do alimento. O Projeto adianta que, em vez de fórmulas milagrosas e padrões alimentares importados, pretende ser uma estratégia para "mudanças na cultura da comunidade no que se refere à alimentação, à nutrição, à saúde e à qualidade de vida de todos, sobretudo, tendo a horta escolar como o eixo gerador de tais mudanças” (PROJETO EDUCANDO COM A HORTA ESCOLAR, 2009a, p. 7).

O objetivo específico do Caderno 1 é que o professor busque uma educação de qualidade e a "formação de pessoas mais conscientes, responsáveis, éticas e instrumentalizadas para a vida em sua geração" (PROJETO EDUCANDO COM A HORTA ESCOLAR, 2009a, p. 8). Também é um instrumento de reflexão individual ou coletiva para que o professor obtenha bom desempenho não somente na coordenação das atividades pedagógicas relacionadas à horta, mas também "adquira clareza da complexidade e das inúmeras implicações sociais de sua ação profissional” (PROJETO EDUCANDO COM A HORTA ESCOLAR, 2009a, p. 8). O Caderno igualmente conta com indicação de bibliografia complementar e uma lista de atividades pedagógicas para os alunos, de maneira que integre a atividade do dia a dia do professor.

Nos Capítulo I, “Que mundo é este?” e II - “Um outro mundo é possível?”, são fornecidos panoramas do contexto político e social em que o PEHE se insere, com os cenários de fome, subnutrição, deficiência de saneamento básico e pobreza. Os capítulos são curtos e complementares, somando um total de 17 páginas. Mais completo, o Capítulo II explica a lei da Política Nacional de Educação Ambiental (PNEA), que também institucionaliza e legaliza a Educação Ambiental (PROJETO EDUCANDO COM A HORTA ESCOLAR, 2009a, p. 16). Tais marcos oficializam a importância da educação ambiental dentro das escolas, 
sendo a horta uma atividade alternativa ao gradeamento da educação ambiental no currículo (PROJETO EDUCANDO COM A HORTA ESCOLAR, 2009a, p. 17).

Os autores apresentam como proposta de trabalho a adoção da horta como um ecossistema - onde educandos, professores, funcionários da escola e a comunidade “[...] podem trabalhar de maneira autônoma, solidária e cooperativa, em favor da aprendizagem de todos e da mudança na cultura alimentar” (PROJETO EDUCANDO COM A HORTA ESCOLAR, 2009a, p. 17). No que tange ao seu caráter de cidadania, a horta se configura "como um mecanismo de oferecer ao cidadão as informações sobre seus direitos quanto à alimentação” (PROJETO EDUCANDO COM A HORTA ESCOLAR, 2009a, p. 17).

Nota-se uma abordagem didática de leis e diretrizes, bem como uma especificação dos princípios que os orientam para a temática da sustentabilidade e meio ambiente, que são: Programa das Nações Unidas para o Meio Ambiente (PNUMA), o Fundo Mundial para a Natureza (WWF) e a União Internacional para a Conservação da Natureza (UICN).

Outro destaque é a explicitação dos princípios que os regem, que são:

1. Construir uma sociedade sustentável;

2. Respeitar e cuidar da comunidade dos seres vivos;

3. Melhorar a qualidade da vida humana;

4. Conservar a vitalidade e a diversidade do planeta Terra;

5. Permanecer nos limites da capacidade de suporte do planeta;

6. Modificar atitudes e práticas pessoais;

7. Permitir que as comunidades cuidem de seu próprio meio ambiente;

8. Gerar uma estrutura nacional para integrar o desenvolvimento e a conservação;

9. Construir uma aliança global.

No que tange ao tópico 9, “Construir uma aliança global”, o material destaca o fato de que o Brasil participa de todas as convenções internacionais relacionadas ao direito à alimentação, que são:

o Declaração Universal dos Direitos Humanos - 1948

o Pacto Internacional de Direitos Econômicos, Sociais e Culturais - 1966

o Conferência Mundial de Alimentação - 1974

o Constituição da República Federativa do Brasil - 1988

o Convenção de Direitos da Criança - 1990

o Conferência Internacional de DH - 1993

o Conferência de Viena - 1993

o Cúpula Mundial de Alimentação - 1996 
Em seguida, tem-se a temática da educação como foco dos capítulos III e IV respectivamente, "Pra que serve a Educação” e "E você, professor, como pode intervir nesse mundo?” No capítulo III, delineia-se o papel do educador, sua missão e leis que regem o sistema educacional. Quanto ao conceito de educação, argumenta-se que o tema não envolve somente o ambiente escolar, mas também outros círculos de convívio, como os que se desenvolvem “[...] na vida familiar, na convivência humana, no trabalho, nas instituições de ensino e pesquisa, nos movimentos sociais e organizações da sociedade civil e nas manifestações culturais” (PROJETO EDUCANDO COM A HORTA ESCOLAR, 2009a, p. 30). Outra questão enfatizada é a necessidade da informação adequada, já que a comunicação é colocada como "um instrumental necessário para que o ser humano viva dignamente” (PROJETO EDUCANDO COM A HORTA ESCOLAR, 2009a, p. 32).

Ainda assim, ressalta-se que não adianta apenas um indivíduo cheio de conhecimento e informações, mas, sim, “é importante compreender que a missão ética da educação é permitir que cada um aprenda a conhecer, a absorver e a utilizar o conhecimento após o período escolar” (PROJETO EDUCANDO COM A HORTA ESCOLAR, 2009a, p. 32). É com o conhecimento e educação que o indivíduo consegue “[...] elaborar pensamentos autônomos e críticos para formular os seus próprios juízos de valor, de modo a poder decidir, por si mesmo, como agir nas diferentes circunstâncias da vida” (PROJETO EDUCANDO COM A HORTA ESCOLAR, 2009a, p. 34).

No capítulo IV, há uma reflexão mais aprofundada no papel da educação, cuja importância reflete-se na "análise e crítica das informações, dos valores e das atitudes contrários à vida em comum, assim como na formulação de proposições alternativas positivas” (PROJETO EDUCANDO COM A HORTA ESCOLAR, 2009a, p. 38). E, no que se refere à intervenção dos indivíduos nas questões sociais, o material diz que "uma coisa é indiscutível: o silêncio e a indiferença diante da situação são as atitudes menos indicadas para intervenção nessa realidade” (PROJETO EDUCANDO COM A HORTA ESCOLAR, 2009a, p. 38).

Nota-se um posicionamento político dos autores do projeto com relação às questões sociais do século XXI. E, no caso específico da temática da alimentação, exemplifica-se que as crianças e os adolescentes não têm acesso a hortaliças e legumes principalmente por "falta de recursos financeiros da família” (PROJETO EDUCANDO COM A HORTA ESCOLAR, 2009a, p. 40), além de fatores culturais ou hábitos alimentares incorretos. Os autores colocam-se como cientes das graves consequências que isso lhes acarreta e, para tanto, usa-se a implementação da horta escolar para “demonstração concreta e real da possibilidade e da 
viabilidade de alcançarmos uma alimentação mais saudável e acessível, do ponto de vista financeiro” (PROJETO EDUCANDO COM A HORTA ESCOLAR, 2009a, p. 40).

O texto situa que a horta, ainda que seja uma estratégia metodológica de segurança alimentar, não tem a ilusão de "que resolve todos os problemas da comunidade no que se refere à fome e à desnutrição” (PROJETO EDUCANDO COM A HORTA ESCOLAR, 2009a, p. 41). O pensamento resume-se no seguinte trecho: "Não queremos fortalecer a ideia de que as resoluções dos problemas sociais do Brasil são pontuais. Elas são estruturais. Estão no nível das questões sociais mais amplas” (PROJETO EDUCANDO COM A HORTA ESCOLAR, 2009a, p. 41). Nota-se um posicionamento de que há pontos profundos que cerceiam a fome e a desnutrição, que é a desigualdade social, o acesso à informação e aos recursos financeiros.

Já a temática da alimentação é o destaque do Capítulo V - “A horta escolar como uma possibilidade de mudança na cultura alimentar" e VI - "É possível pensar a escola e o currículo escolar com os olhos no mundo?”. No Capítulo V, um esquema mostra todas as correlações da alimentação saudável com outras temáticas, conforme a figura a seguir:

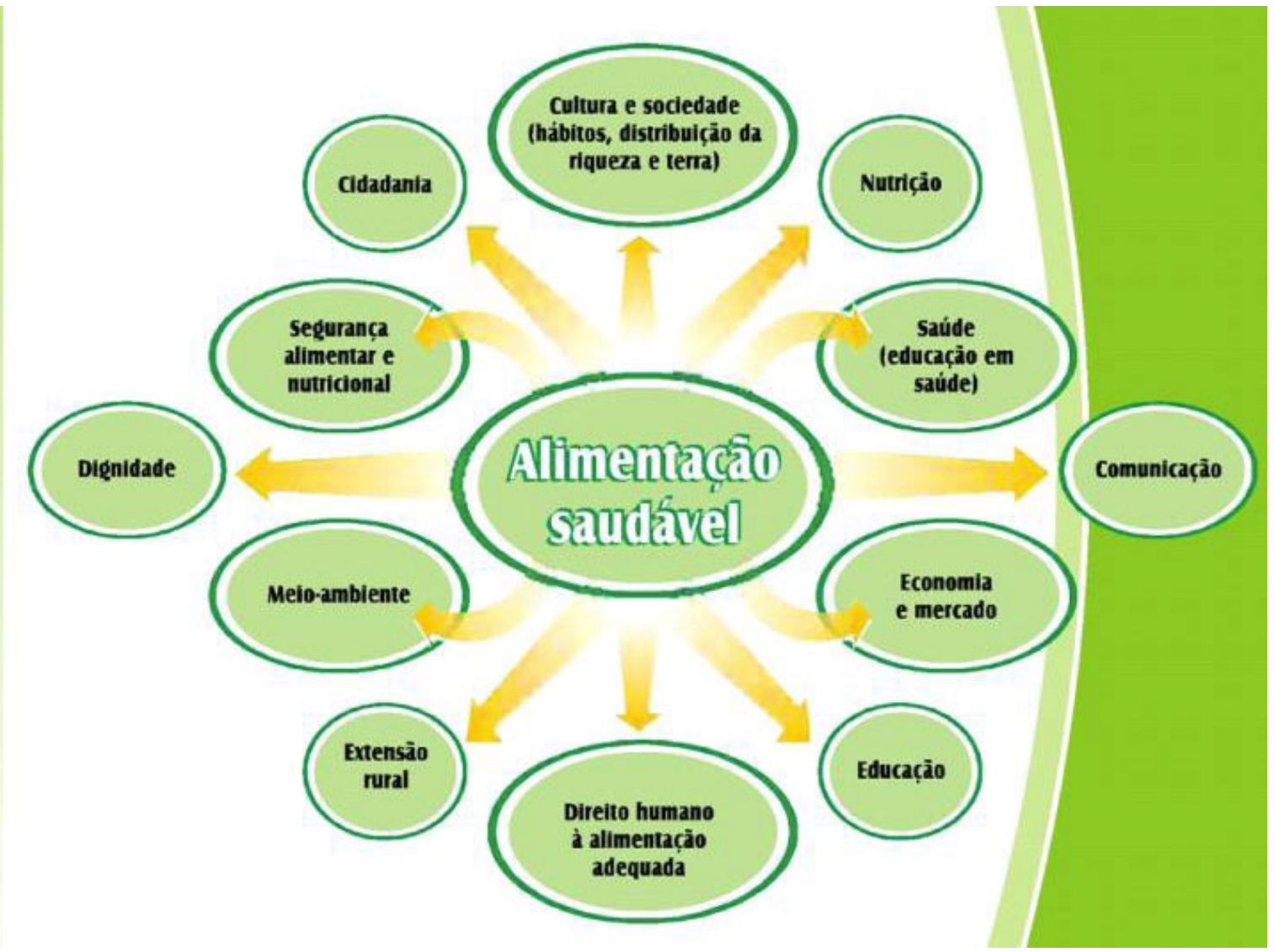

Figura 2 - Os diversos aspectos que envolvem uma alimentação saudável (PROJETO EDUCANDO COM A HORTA ESCOLAR, 2009a, p. 43). 
Por ser vinculada a questões mais amplas, a alimentação saudável é alcançada segundo a análise acerca do tema, "de uma forma mais ampliada, [...] estabelecendo uma intervenção na cultura do nosso povo” (PROJETO EDUCANDO COM A HORTA ESCOLAR, 2009a, p. 43). Outro aspecto destacado no material didático é que as questões relativas à alimentação, ao ambiente e à nutrição são temas absolutamente atuais e diretamente vinculados à qualidade de vida humana, tendo a horta escolar como um eixo gerador de “dinâmicas comunitárias, educação ambiental e alimentação saudável e sustentável” (PROJETO EDUCANDO COM A HORTA ESCOLAR, 2009a, p. 46).

O Capítulo VI destaca a importância de uma revisão do currículo escolar atual, de maneira que perpasse a visão de um conjunto de conhecimentos determinados a priori, o que impede o professor de perceber "a complexidade e amplitude da ação pedagógica, uma vez que se sentem responsáveis apenas pelos conteúdos [...] prévia e arbitrariamente elencados” (PROJETO EDUCANDO COM A HORTA ESCOLAR, 2009a, p. 52). Em substituição, o material propõe “(re)conceituar o currículo na perspectiva crítica e atual, como um conjunto sistematizado de elementos que compõem o processo educativo e a formulação humana” (PROJETO EDUCANDO COM A HORTA ESCOLAR, 2009a, p. 52). Para tanto, discutir o currículo envolve levantar "questões que realmente importam e têm espaço concreto no cotidiano” (PROJETO EDUCANDO COM A HORTA ESCOLAR, 2009a, p. 52).

O caderno salienta que a alimentação é uma condição que perpassa "vários aspectos da constituição humana”, já que “diz respeito à saúde do corpo e qualidade de vida; o acesso a esta alimentação diz respeito à sua inserção socioeconômica e à sua relação com o meio ambiente” (PROJETO EDUCANDO COM A HORTA ESCOLAR, 2009a, p. 49). Além disso, embora explicite que a horta não vai mudar o mundo, um dos pontos enfatizados é o objetivo maior da horta escolar, que é o de realizar a "abordagem das temáticas ambiente, alimentação e nutrição com vistas a mudanças dos maus hábitos alimentares e ambientais, por meio de uma prática pedagógica dinâmica, prazerosa e geradora de aprendizagens” (PROJETO EDUCANDO COM A HORTA ESCOLAR, 2009a, p. 51).

Para mostrar a importância da interconexão entre os fatos, traz-se à tona o conceito de transdisciplinaridade, cujo resumo consta no quadro abaixo: 


\section{Transdisciplinaridade}

O saber percorre as diversas ciências, indo para além delas, sem se preocupar com limites ou fronteiras.

Procura-se a abertura de todas as ciências, reconciliando ciências exatas, humanas, arte, literatura, poesia, experiência interior.

Seu objetivo: unidade do conhecimento, indo para além das investigações científicas e agregando novos saberes.

Suas características fundamentais são o rigor, abertura e tolerância.

Procura integrar a investigação com outros modos de conhecimento como a religião, o transcendente e o antropológico cultural com suas riquezas de tradições.

Figura 3 - Transdiciplinaridade: conceitos e características (PROJETO EDUCANDO COM A HORTA ESCOLAR, 2009a, p. 56).

A transdisciplinaridade é uma das características centrais do projeto, e será tratada em diversos momentos como forma de superar a organização disciplinar estanque, bem como mostrar uma percepção integral do conhecimento gerado.

O Capítulo VII - "Qual o papel do professor e da professora no desenvolvimento do currículo escolar?”, adota como referência principal os pensamentos de Paulo Freire, elencando características dos bons educadores, além de inserir poemas e pensamentos sobre educação e aprendizado pedagógico. Outro educador destacado é José Bernardo Toro, cujas ideias também orientaram na formulação e concepção de currículo por parte dos autores.

Considera-se que o PEHE estimula a existência de um processo de ensinoaprendizagem mais dinâmico e prazeroso. Isso porque fornece, por meio da horta, metodologias alternativas em sala de aula, mas, de maneira “[...] simples, variadas, que foquem a pesquisa, a descoberta, que privilegiem o trabalho em grupo, a construção e o relato socializador de conhecimentos” (PROJETO EDUCANDO COM A HORTA ESCOLAR, 2009a, p. 62). 
Ainda assim, no final do capítulo há um grande destaque para o fato de que a metodologia alternativa proposta pelo PEHE não descarta ou desvaloriza os conteúdos escolares. Para o PROJETO EDUCANDO COM A HORTA ESCOLAR (2009a, p. 67), “[...] ao contrário, são contextualizados, dinamizados e transformados em saberes construídos por meio da pesquisa e da investigação, ao invés da simples transmissão do professor e da memorização dos educandos”.

Já os Capítulos VIII - "Como avaliar se o Projeto 'Educando com a horta escolar' está alcançando os objetivos na sua escola” - e IX - "Quem pode contribuir com a escola nesse trabalho inovador?” - propõem questionamentos sobre a avaliação do projeto e como incentivar a participação dos discentes, docentes e da comunidade. Composto por 4 páginas, o Capítulo VIII resume e reforça como a horta pode despertar o interesse não só dos alunos, como também da comunidade. Para completar o pensamento, o Capítulo IX exemplifica como o PEHE pode ser expandido além dos muros escolares, com parcerias como empresas, jornais da cidade, Centros de Saúde, entre outros.

Ao final do Caderno 1, há um anexo com uma lista de atividades, somando 29 sugestões. O objetivo é ajudar o professor a definir as atividades do dia a dia (PROJETO EDUCANDO COM A HORTA ESCOLAR, 2009a), e a metodologia foi desenvolvida de maneira a promover a participação, onde “[...] o diálogo, o trabalho coletivo, o princípio do prazer e de solidariedade [...] sejam ingredientes absolutamente necessários” (PROJETO EDUCANDO COM A HORTA ESCOLAR, 2009a, p. 78). A organização das atividades sugeridas se dá basicamente em quatro tópicos:

1) Como a atividade pode ser desenvolvida;

2) Quais são os seus objetivos;

3) Qual é o resultado esperado;

4) Algumas recomendações.

Na elaboração das atividades, pode-se notar que os autores se preocuparam com a questão da transdisciplinaridade, visto que integram as disciplinas aos temas da atualidade. Podem-se citar os seguintes exemplos:

- Atividade 5: Construindo o minhocário, produzindo o húmus

Disciplina abordada: Química - análise composição do húmus;

Tema complementar: construção do minhocário como atividade ecológica.

- Atividade 11: Estudando os microclimas

Disciplina abordada: Geografia - topografia e condições de terreno;

Tema complementar: como condições climáticas afetam a elaboração da horta. 
- Atividade 16: Criando o Jornal da Escola

Disciplina abordada: Português - escrita de um jornal;

Tema complementar: influência da mídia na realidade local.

Conclui-se que o Caderno 1 contextualiza a sociedade e o mundo atual, baseado no tema central da educação, bem como situa as questões emergentes do meio ambiente, da alimentação e do professor. Dispõe também de indicadores e referências estatísticas mais gerais, como indicadores socioeconômicos, poemas e reflexões de educadores.

\subsubsection{Caderno 2 - Orientações para implantação e implementação da horta escolar}

\section{Páginas: 43}

\section{Capítulos: 6}

Objetivo: oferecer informações sobre como implementar a horta escolar.

Com técnicas e procedimentos para a execução da horta - plantio, cuidados, cultivos, manutenção, técnicas e profissionais envolvidos, o Caderno 2 - "Orientações para implantação e implementação da horta escolar” - fornece os subsídios técnicos para que docentes, alunos e a comunidade executem a horta.

O Capítulo 1 ("Introdução") é, em grande parte, teórico, e situa a agricultura no contexto da evolução social e científica. Conceitua o termo "agricultura sustentável”, que é a existência de um objetivo social e produtivo, segundo a adoção de "outro padrão tecnológico, que seja ético, não use de forma predatória os recursos naturais e nem seja agressivo ao meio ambiente" (PROJETO EDUCANDO COM A HORTA ESCOLAR, 2009b, p. 9). Pontua também a necessidade crescente de se adotar uma "relação cada vez menos conflituosa entre agricultura e meio ambiente" (PROJETO EDUCANDO COM A HORTA ESCOLAR, 2009b, p. 7), elencando as diferentes possibilidades de produção de alimentos, além dos processos atuais da crescente modernização da agricultura.

Entre as alternativas de produção agrícola que visam diminuir os impactos no meio ambiente, os autores citam a produção agroecológica e as hortas. Embora a agroecologia vise um sistema agrícola produtivo que potencialize a biodiversidade ecológica "sem consequências degradantes para a natureza e para a sociedade e [...] seus produtos ainda são muito caros e inacessíveis para a grande maioria da população" (PROJETO EDUCANDO COM A HORTA ESCOLAR, 2009b, p. 8). Já no outro modelo de cultivo em escala menor, as hortas, também produzem hortaliças de qualidade, mas com custos mais baixos. Nas hortas, observam-se as leis da natureza, respeitando o meio ambiente e contribuindo na 
preservação dos recursos naturais (PROJETO EDUCANDO COM A HORTA ESCOLAR, 2009b). Neste mesmo documento, são apresentados dois tipos de hortas:

1. Hortas Familiares - cuidada por uma única família;

2. Hortas Comunitárias e Escolares - a produção de hortaliças é feita em conjunto ou por um grupo de pessoas.

Já no Capítulo 2 - "Hortaliças" - mostra-se um posicionamento diante do baixo consumo de hortaliças no Brasil: aponta-se que, embora parte da população esteja consciente “da necessidade de consumir esses produtos na alimentação diária [...] fatores como preço, costume e falta de produtos de qualidade têm contribuído para seu baixo consumo" (PROJETO EDUCANDO COM A HORTA ESCOLAR, 2009b, p. 11). Assim como no Caderno 1, salienta-se o fator preço pelo baixo consumo de alimentos saudáveis, bem como o costume e falta de produtos de qualidade.

Em suas primeiras linhas, o Capítulo 3 - “Desperdício” - explicita que o Brasil é líder mundial em desperdício de comida, mostrando uma inquietude a respeito da distribuição dos alimentos: “[...] entre a colheita no campo e a mesa do consumidor, as perdas de alimentos chegam a variar de 20\% a 60\%” (PROJETO EDUCANDO COM A HORTA ESCOLAR, 2009b, p. 15). Outro destaque é o de que mais da metade do lixo produzido no Brasil é composto por restos de alimentos, e que, a cada ano, 35 milhões de toneladas de grãos, frutas, hortaliças e produtos de origem animal são perdidos entre a produção no campo ao consumo final (PROJETO EDUCANDO COM A HORTA ESCOLAR, 2009b). Esse capítulo acrescenta também que muitos são os culpados pelo desperdício, já que a perda de alimentos seria suficiente para "fornecer cestas básicas a alguns milhões de famílias brasileiras, hoje excluídas do mercado de alimentos por insuficiência de renda” (PROJETO EDUCANDO COM A HORTA ESCOLAR, 2009b, p. 15).

Esse capítulo salienta a importância de o indivíduo tomar consciência de que a produção, distribuição e o consumo final dos alimentos são processos conectados, e que o desperdício é uma das consequências da falta de conexão entre esses processos. O capítulo finaliza indicando que evitar o desperdício é “[...] muito mais que uma forma de economizar, é um exercício de cidadania que demonstra a preocupação dos indivíduos com o futuro” (PROJETO EDUCANDO COM A HORTA ESCOLAR, 2009b, p. 17).

Os Capítulos 4 - “Implantação da horta escolar” - e Capítulo 5 - “Iniciando o plantio na Horta Escolar” - são baseados em conhecimentos e técnicas de plantio, com ilustrações de ferramentas a serem usadas, tabelas de plantio e colheita, área de plantio, dicas de adubagem e como montar húmus e compostagem orgânica. Por fim, o Capítulo 6 - "Manutenção da Horta 
Escolar" - propõe dicas de como manter a horta durante o recesso escolar, com dicas de conservação da horta para alunos, professores e a comunidade. Para tanto, disponibiliza técnicas de controle de insetos e pragas nas hortaliças.

O Caderno 2 foi escrito com formatação e conteúdos mais técnicos do que os Cadernos 1 e 3 e, por conta disso, possui uma temática de menor interesse para a pesquisa. Ainda assim, contextualiza a agricultura como conectada às questões de produção, distribuição e consumo de alimentos, mostrando uma visão ampliada do assunto e outras possibilidades de se produzir comida.

\subsubsection{Caderno 3 - Alimentação e nutrição: caminhos para uma vida saudável}

\section{Páginas: 86}

\section{Capítulos: 7}

Objetivo: oferecer informações sobre alimentação, nutrição e saúde.

Por ser o Caderno com a temática que mais se aproxima dos objetivos da pesquisa, o Caderno 3 terá uma análise detida e mais detalhada, já que, como afirmam os autores na Introdução, "[...] contém algumas das informações sobre alimentação que consideramos básicas” (PROJETO EDUCANDO COM A HORTA ESCOLAR, 2009c, p. 9).

Com 86 páginas divididas em sete capítulos, logo na “Introdução” manifesta seu caráter político, visto que o tema central é a alimentação e suas implicações socioeconômicas, bem como a implantação de políticas públicas. Ressalta-se a expectativa de que se melhore a qualidade da educação no país, mas que se tenha a clareza de que "muito da qualidade que desejamos está relacionada às questões socioeconômicas, culturais, de definição e implantação de políticas públicas, entre outras” (PROJETO EDUCANDO COM A HORTA ESCOLAR, 2009c, p. 9).

O Capítulo I - “A Cultura Alimentar no Brasil” - possui 16 páginas, é o mais longo e crítico do Caderno 3. Contesta o papel da mídia na alimentação, o acesso ao alimento e o paradoxo de que $49 \%$ da população brasileira adulta possui sobrepeso, em contraste com 29\% da população que sofre de algum nível de insegurança alimentar.

Para tanto, propõe uma visão sobre o alimento como expressão de identidades sociais, baseadas na alimentação, isto é, a cultura alimentar, cujo conceito é colocado a seguir: 
relacionados com a identidade cultural de um povo, isto é, são fatores desenvolvidos ao longo do tempo, que distinguem um grupo social de outro e que estão intimamente relacionados com a história, o ambiente e as exigências específicas do dia a dia. (PROJETO EDUCANDO COM A HORTA ESCOLAR, 2009c, p. 12).

Ao longo do capítulo, notam-se menções recorrentes a respeito da relação entre mídia/publicidade nos hábitos alimentares, bem como a importância de o cidadão exigir uma informação adequada sobre o produto consumido. Uma provocação aos meios de comunicação se dá na afirmação de que, se, em outro momento histórico, a cultura alimentar se modificava quando algum povo vinha para a nação, hoje, “as transformações se dão com base nos fatores socioeconômicos e sociais e são promovidos, principalmente, pelos instrumentos de comunicação de massa” (PROJETO EDUCANDO COM A HORTA ESCOLAR, 2009c, p. 13). Outros fatores para as mudanças alimentares são a falta de tempo dos pais e a falta de conhecimento sobre alimentação saudável, bem como a influência do grupo social, como aponta o Projeto Educando com a Horta Escolar (2009c, p. 14).

Ao entrar no assunto alimentação saudável, define-se também o conceito de saúde, colocado como "um patrimônio que permite às pessoas adquirirem maior controle sobre sua qualidade de vida” (PROJETO EDUCANDO COM A HORTA ESCOLAR, 2009c, p. 15). Os produtores do material adotam posicionamento crítico ao explicitar que, como educadores, pretendem que os educandos tenham mais discernimento para "enfrentar e questionar as novas regras que a sociedade do consumo tenta nos impor” (PROJETO EDUCANDO COM A HORTA ESCOLAR, 2009c, p. 16).

Em seguida, o capítulo conceitua dois dos temas que norteiam todo o projeto, que são o Direito Humano à Alimentação Adequada (DHAA) e Segurança Alimentar e Nutricional (SAN). Por Direitos Humanos, entende-se que “[...] são aqueles que todo indivíduo tem, única e exclusivamente, por ter nascido humano” (PROJETO EDUCANDO COM A HORTA ESCOLAR, 2009c, p. 17). E ainda "dizem respeito a direitos que foram estabelecidos em declarações e tratados internacionais, negociados entre todos os povos do mundo e firmados pelos representantes desses povos” (PROJETO EDUCANDO COM A HORTA ESCOLAR, 2009c, p. 17). É obrigação dos Estados “respeitar, proteger, promover e prover os Direitos Humanos” (PROJETO EDUCANDO COM A HORTA ESCOLAR, 2009c, p. 17). Quanto ao $\mathrm{DHAA}^{18}$, este se realiza "quando cada homem, mulher e criança, sozinho ou em companhia de outros, tem acesso físico e econômico, ininterruptamente, à alimentação adequada ou aos

\footnotetext{
${ }^{18}$ O termo baseia-se nas Diretrizes Voluntárias Internacionais, com base no Comentário Geral n.12 do Comitê de Direitos Econômicos, Sociais e Culturais da ONU.
} 
meios para sua obtenção” (PROJETO EDUCANDO COM A HORTA ESCOLAR, 2009c, p. 18). Em seguida, é feito um quadro, que destaca o conceito de Segurança Alimentar e Nutricional, com base na definição do CONSEA, que é

O direito de todos ao acesso regular e permanente a alimentos de qualidade, em quantidade suficiente, sem comprometer o acesso a outras necessidades essenciais, tendo como base em práticas alimentares promotoras de saúde, que respeitem a diversidade cultural e que sejam social econômica e ambientalmente sustentáveis (PROJETO EDUCANDO COM A HORTA ESCOLAR, 2009c, p. 18). ${ }^{19}$

Em complemento, os autores ressaltam que o alimento é um direito e precisa ser discutido "com todos os cidadãos brasileiros para garantir que todos tenham acesso" (PROJETO EDUCANDO COM A HORTA ESCOLAR, 2009c, p. 19). E, no caso do Brasil, dá-se ênfase a outra contradição, que consiste no fato de o país ser o quarto país exportador de alimentos do mundo e, ao mesmo tempo, o sexto maior em subnutrição (PROJETO EDUCANDO COM A HORTA ESCOLAR, 2009c, p. 20). O Caderno fornece diversos dados estatísticos de fontes oficiais e órgãos estatais para demonstrar o cenário da alimentação no Brasil, sempre pontuados com questionamentos que levantam provocações, como a seguinte consideração sobre a alimentação em nosso país: “A desnutrição e a má alimentação estão mais associadas com o hábito alimentar do que com o acesso à alimentação? Deixem os estudiosos desse assunto pensarem sobre isto...” (PROJETO EDUCANDO COM A HORTA ESCOLAR, 2009c, p. 21).

Após delinear o cenário da alimentação brasileira, resume-se a provocação com estatísticas sobre obesidade e desnutrição: “em 1975, o Brasil contava com um pouco mais de $8 \%$ de crianças e adolescentes subnutridos e cerca de metade, $4 \%$, de obesos. Esse quadro se inverteu, pois, atualmente, os dados apontam para 9\% de obesidade e só 3\% de subnutridos” (PROJETO EDUCANDO COM A HORTA ESCOLAR, 2009c, p. 23). O final do capítulo ressalta ainda a coexistência não só da obesidade, como também dos distúrbios alimentares entre crianças e adolescentes, dando um exemplo de uma estudante com quadros de bulimia. Ao situar as doenças decorrentes da má alimentação, os produtores do material reforçam o papel da mídia na criação de estereótipos sobre o corpo: afirmações como padrões físicos que a mídia impõe, bem como o questionamento sobre o que significa esse padrão para o mercado de consumo, explicita as críticas aos valores vigentes na sociedade.

O Capítulo II - “Alimentação Saudável. O que é isto?” - inicia com a definição de alimentação saudável, que é a mesma encontrada no Brasil (2006): é “aquela baseada em

\footnotetext{
${ }^{19}$ A definição mais aprofundada de SAN consta no capítulo 6, “Alimentação e Comunicação.”
} 
alimentos que atendem às necessidades do nosso organismo. Essas necessidades mudam de acordo com a idade e o sexo de cada um de nós e, ainda, com as atividades que exercemos” (PROJETO EDUCANDO COM A HORTA ESCOLAR, 2009c, p. 27). Assim, uma alimentação saudável “[...] é aquela planejada com alimentos de todos os tipos, sem abusos e também sem exclusões, que contêm todos os nutrientes e é de procedência conhecida” (PROJETO EDUCANDO COM A HORTA ESCOLAR, 2009c, p. 31).

Em seguida, insere a imagem da roda dos alimentos, versão similar à pirâmide alimentar, com distribuição de quantidade que deve ser ingerida conforme os grupos alimentares (arroz, pão, massas, verduras, frutas). Um grande destaque é dado para a água, colocada como o principal componente do organismo.

É colocado à tona o seguinte questionamento: Mas, afinal, o que é uma alimentação saudável? A resposta vem da mesma diretriz encontrada no Brasil (2005), isto é, que, para se ter uma alimentação saudável, “não é preciso gastar mais, comer somente verduras e legumes, consumir somente produtos requintados, difíceis de serem encontrados ou comer apenas alimentos de sabor desagradável” (PROJETO EDUCANDO COM A HORTA ESCOLAR, 2009c, p. 31).

Em contrapartida, são apresentados alguns tópicos sobre uma refeição saudável, como:

- respeita e valoriza os hábitos locais;

- tem garantia de custo acessível;

- sabor agradável;

- é variada;

- colorida;

- garante a harmonia;

- é segura (PROJETO EDUCANDO COM A HORTA ESCOLAR, 2009c, p. 31).

Como complemento, são fornecidas algumas dicas para se ter uma alimentação saudável, como: evitar longos períodos sem comer; comer devagar; evitar substituir refeições principais por lanches; praticar exercícios físicos; evitar alimentos ricos em gorduras e açúcares; entre outros.

Tais diretrizes são transcrições encontradas no Guia Alimentar (BRASIL, 2006), que, por sua vez, baseou suas diretrizes em relatórios da Organização Mundial da Saúde (OMS) e do Ministério da Saúde. Assim como no Guia (BRASIL, 2006), há um destaque para o papel da água na boa nutrição e saúde do indivíduo, bem como uma separação dos grupos alimentares, que são: o grupo dos pães e massas; vegetais e frutas; carnes, peixes, feijões, ovos, leite e derivados; açúcares, óleos e gorduras. O último tópico trata da alimentação para o desenvolvimento humano, dando destaque para a amamentação como elemento fundamental na prevenção de doenças e na relação entre mãe e filho. 
No Capítulo III - “O que são e por que comer hortaliças” - continuam as referências ao Guia Alimentar (BRASIL, 2006), mostrando algumas recomendações quanto à alimentação. Outro ponto são as doenças decorrentes de uma alimentação não saudável, com uma breve descrição de cada uma delas: anorexia e bulimia, anemia, desnutrição, diabetes, doenças cardiovasculares, obesidade e osteoporose. Por fim, o Guia enfatiza a importância de condutas saudáveis, que promovam aumento da autoestima e controle do peso, visto que estas “[...] são instrumentos indispensáveis para alcance da qualidade de vida” (PROJETO EDUCANDO COM A HORTA ESCOLAR, 2009c, p. 40). O capítulo finaliza com um texto complementar, que mostra a importância de se pensar no reaproveitamento dos alimentos.

O Capítulo IV - “A Horta como estratégia de mudança da cultura alimentar” - mostra a importância de se conhecer a origem do alimento que chega às mesas - sua procedência, que tipo de trabalho o agricultor teve de fazer para que o produto chegasse ao consumo, como a carne foi manipulada, entre outros aspectos. Pensando na temática da produção do alimento, o Guia enfatiza a questão da desinformação, que acarreta a formação de pessoas "sem a necessária compreensão de que o homem e a mulher são produtores de sua história; de que a sociedade é constituída daquilo que o conjunto de seres humanos, pelas várias gerações, vão criando como cultura” (PROJETO EDUCANDO COM A HORTA ESCOLAR, 2009c, p. 45). Complementa o documento que a ausência de informação modifica a história das pessoas, já que “[...] não favorece a percepção do valor do trabalho, do homem, do outro, do planeta” (PROJETO EDUCANDO COM A HORTA ESCOLAR, 2009c).

A contrapartida à desinformação é a horta, colocada como proposta de estreitar a relação entre o estudante e o alimento (PROJETO EDUCANDO COM A HORTA ESCOLAR, 2009c, p. 45). E o capítulo se encerra com um diagrama, que resume o movimento da relação entre estudante e alimento por meio da horta, cuja imagem se encontra a seguir: 


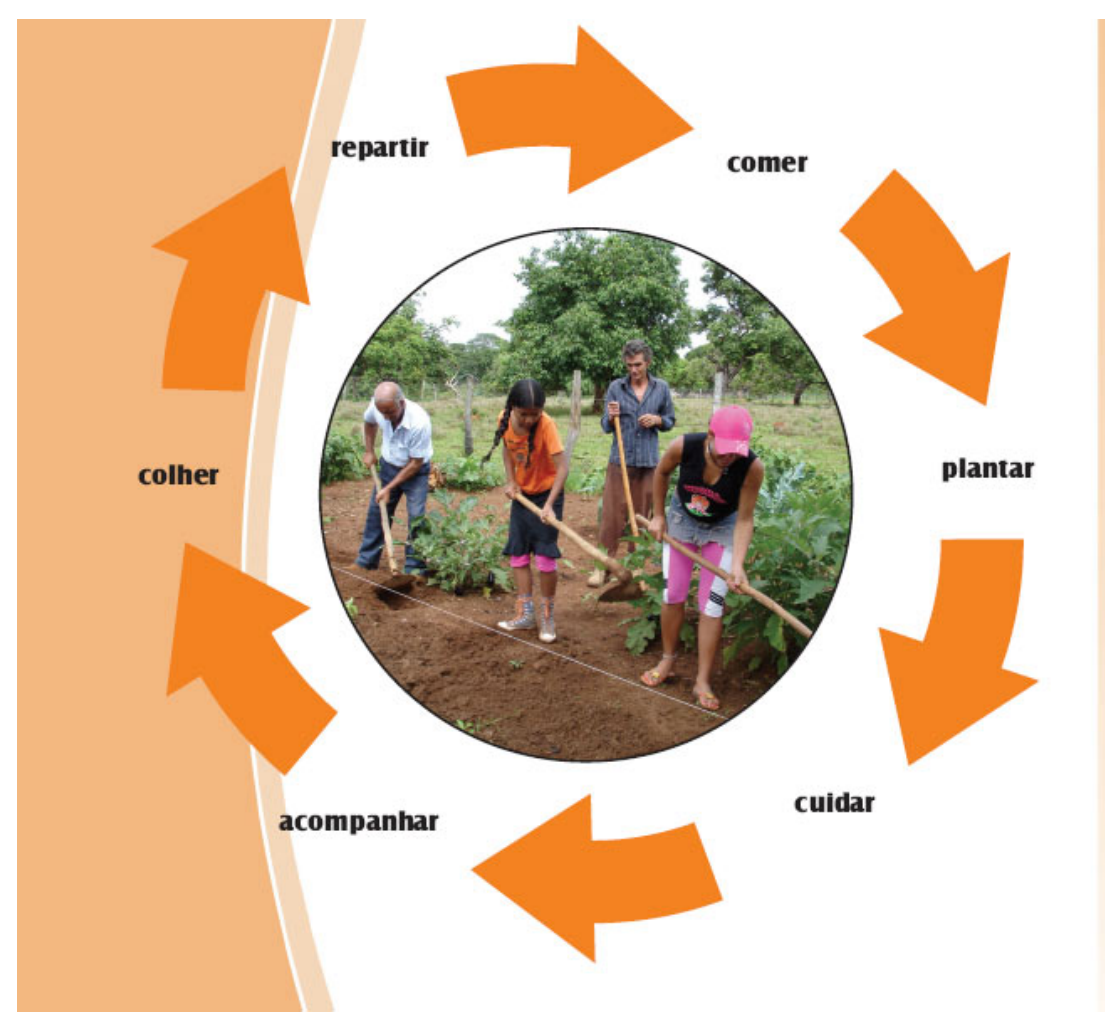

Figura 4 - Relação do estudante com o alimento pela horta (PROJETO EDUCANDO COM A HORTA ESCOLAR, 2009c, p. 46).

O Capítulo V - "Fazendo a horta” - é inteiramente dedicado a uma tabela dividida por cada tipo de alimento, seu respectivo valor nutricional, período em que está bom para o consumo, como deve ser consumido e conservado, bem como dicas para uma alimentação saudável. Em seguida, há um quadro com explicação sobre as vitaminas, as fontes de alimentos ricos em vitaminas, doenças provocadas pela sua carência e a função no organismo. Uma última tabela apresenta os minerais presentes nos alimentos, mostrando sua atuação e principais fontes.

Já a procedência da merenda escolar do aluno é o tema central do Capítulo VI "Conversando sobre a alimentação e a cozinha da escola." Os autores afirmam que a merenda vem do Programa Nacional de Alimentação Escolar (PNAE), e que assegura o direito à alimentação, a todos os escolares de escolas públicas ou filantrópicas, por meio da transferência de recursos financeiros (PROJETO EDUCANDO COM A HORTA ESCOLAR, 2009c, p. 62). O caderno explica também como é definido o cardápio dos estudantes, a influência da harmonia na cozinha em que se produz o alimento e a importância da segurança alimentar no ambiente de trabalho. Como parte de uma atividade escolar, no capítulo consta anexa uma simulação de formulário de atuação da Vigilância Sanitária, com itens que permitem avaliar se a cozinha da escola está de acordo com as diretrizes sanitárias. 
No Capítulo VII - “Contribuindo com o seu trabalho” - são oferecidos aos professores 11 sugestões de atividades que envolvem a alimentação, como: visita ao supermercado; elaboração de rótulos de alimentos; pesquisa sobre preferência alimentar dos estudantes; visita à cozinha da escola; explicações sobre o lixo moderno, bem como melhor aproveitamento e conservação dos alimentos; preparação de alimentos produzidos na horta; como trabalhar com a roda alimentar.

Cada atividade possui tópicos como Objetivos, Materiais Necessários e Procedimentos, sendo que parte das atividades foi originalmente publicada nos Cadernos de Nutrição da Universidade de Brasília - que, atualmente, é uma das coordenadoras da nova versão do PEHE. Ao final do caderno, há dicas de literatura infanto-juvenil, jogos, materiais de apoio e sites.

O Caderno 3 é o mais específico no que tange ao assunto alimentação saudável, e mescla assuntos técnicos - como tabela de valores nutricionais - a posicionamentos políticos sobre o tema.

\subsection{Material didático: apreciação crítica}

O objeto de estudo para esta pesquisa consiste em um conteúdo educativo voltado para adultos que irão repassar tal conhecimento para seus alunos. Traz elementos técnicos e teóricos, propondo uma discussão mais ampla em torno da horta.

Com base nos estudos e nas releituras do objeto, pode-se afirmar que o PEHE é transdisciplinar e uma estratégia em Segurança Alimentar e Nutricional (SAN), com metodologia fornecida pela Organização das Nações Unidas para a Agricultura e Alimentação (FAO). Transdisciplinar porque é possível observar um cuidado na integração das disciplinas escolares com assuntos atuais para tratar do assunto da alimentação. E consiste em uma estratégia em SAN pelo referencial teórico e metodológico, baseados em publicações de órgãos governamentais e internacionais, tendo como conceitos centrais a Segurança Alimentar e Nutricional (SAN) e suas dimensões que implicam no Direito Humano à Alimentação Adequada (DHAA) e na Soberania Alimentar.

Vale ressaltar que, por ser realizado pelo Fundo Nacional de Desenvolvimento da Educação (FNDE) / Programa Nacional de Alimentação Escolar (PNAE), os princípios destas entidades são mencionados diversas vezes ao longo do material didático, como a defesa da agricultura familiar, dos alimentos regionais e da cultura alimentar. Outro ponto que também 
merece ser destacado é o fato de a equipe do projeto ter escolhido municípios com base no critério de IDH. Nota-se uma preocupação por parte dos organizadores em selecionar municípios cujo critério não é somente o crescimento econômico, mas, sim, de Desenvolvimento Humano.

No que concerne especificamente ao material didático, notou-se que os textos são bem opinativos e que, por vezes, a escrita é pouco fluida. Por outro lado, observa-se a simplicidade da diagramação, bem como a estrutura dos Cadernos, o que permite uma leitura dinâmica.

No que tange à análise temática do objeto, antes de iniciá-la, é válido reforçar que a escolha do tema se deu pelos seguintes critérios:

1) Frequência e destaque do assunto em termos textuais e gráficos;

2) Checagem de referências, marcos e fontes adotadas pelos autores;

3) Relevância para a pesquisa.

Com base nos critérios acima, em seguida, foram selecionados os temas centrais que possibilitaram a análise do objeto, cujos tópicos se encontram a seguir:

1) Alimentação: acesso e intersetorialidade

2) Educação nutricional e participação social

3) Cidadania, cotidiano, informação

4) Mídia e alimentação

5) Alimento saudável: sentidos e significações

6) PEHE e a construção da cidadania

\section{1) Alimentação: acesso e intersetorialidade}

O PEHE propõe que se enxergue a alimentação de maneira intersetorial, envolvendo diversos saberes para tratar do tema. O projeto trata da complexidade dos fenômenos, e propõe que se repense as causas mais profundas dos fenômenos da alimentação, dando destaque principalmente às questões sociais e políticas. Dessa forma, trata que as deficiências alimentares presentes na sociedade advêm de fatores diversos - como cultura, política, economia, meio ambiente, saúde.

No entanto, ainda que o PEHE elenque a diversidade de fatores, o maior destaque para a deficiência nutricional está no acesso, sobretudo pelas condições econômicas. Outro ponto é que os cadernos reiteradamente denunciam que a questão do acesso é diretamente relacionada com a desigualdade social do Brasil.

A questão da intersetorialidade pode ser exemplificada em dados encontrados no Caderno 1 - “A Horta Escolar dinamizando o currículo da escola” (Capítulo I: “Que mundo é 
este?”) e Caderno 3 - “Alimentação e nutrição: caminhos para uma vida saudável” (Capítulo I - “A Cultura Alimentar no Brasil” e O Capítulo II - “Alimentação Saudável. O que é isto?”). Nestes, constam uma das diretrizes em SAN, que é superar a visão estritamente dietética da alimentação e nutrição, ampliando-a em dimensões mais amplas como meio ambiente, cultura, produção, abastecimento, comercialização, meios de comunicação e determinantes de consumo. É possível detectar que as temáticas relacionadas à abordagem intersetorial e a necessidade do acesso aos alimentos são diretrizes que se referem à garantia da Segurança Alimentar e Nutricional, de acordo com os documentos e autores consultados ${ }^{20}$. Tal visão também encontra consenso com o movimento da Promoção da Saúde, e pode ser percebido quando os autores conceituam saúde como “[...] um patrimônio que permite às pessoas adquirirem maior controle sobre sua qualidade de vida” (PROJETO EDUCANDO COM A HORTA ESCOLAR, 2009c, p. 15).

Quanto à questão do acesso aos alimentos, pelas descrições é possível perceber que em diversas passagens do material didático menciona-se o preço como fator limitante para uma alimentação saudável. Um exemplo encontra-se no Caderno 2, em que se explicitam possibilidades mais sustentáveis de produção de alimentos, propondo a horta como alternativa à agroecologia - mais cara e inacessível para grande parte da população.

\section{2) Educação nutricional e participação social}

Outro aspecto que envolve a noção de SAN, e é reafirmado pelo PEHE, é a participação social. Ao longo do material didático, pode-se notar a valorização da participação não só dos docentes e discentes, como de toda a comunidade, bem como a conexão com a agricultura familiar, de forma que amplie a ação para além dos muros da escola. Neste sentido, Bógus e Whestphal (2007) apontam a importância da participação social como elemento na promoção da saúde para práticas de qualidade de vida, conforme salientado no capítulo “Comunicação e Saúde”.

Valoriza-se a participação social e a educação nutricional de maneira que fomente a formação cidadã - ultrapassando a ideia de instrução formal e fragmentada. O reforço à educação nutricional condiz com as diretrizes da Política Nacional de Alimentação e Nutrição (PNAN), que também dá importância à educação nutricional como estratégia central para a

\footnotetext{
${ }^{20}$ Documentos: CONSEA (2010), “Guia Alimentar para a população brasileira” (BRASIL, 2006), Declaração de Roma (1996), PNAN (1999); Autores: BÓGUS (2007), COSTA (2011), MENDES (2007), POLLAN (2007, 2008, 2010), WESTPHAL (2007).
} 
ação preventiva de desnutrição, a promoção de práticas alimentares e de estilo de vida saudáveis.

É possível encontrar o incentivo à participação quando se fala das atividades extracurriculares, como a sugestão de elaboração de um jornal da escola, em que os alunos entrevistam cidadãos e figuras públicas em torno do tema da horta escolar. Outras atividades são as confraternizações, como a "Festa da Identidade: conhecendo nosso município" (PROJETO EDUCANDO COM A HORTA ESCOLAR, 2009a, p. 94), uma festa que viabiliza a participação de alunos, professores, pais e a comunidade. Neste caso, nota-se uma preocupação em unir a educação nutricional com a participação social.

\section{3) Cidadania, cotidiano, informação}

A informação é colocada como instrumento da cidadania ${ }^{21}$ e aspecto central para que se assegure a SAN - a mesma premissa encontrada nos documentos consultados para o trabalho. Já o cotidiano é identificado como principal elemento do exercício da cidadania e de mudanças estruturais na sociedade. Com isso, é constatado que o tripé para a formação cidadã se dá pela formação crítica e sua aplicação no cotidiano.

Observa-se também que os elaboradores do PEHE possuem a ciência dos problemas estruturais do Brasil, mas que, nem por isso, desaprovam iniciativas que atuam no âmbito local. Nesse sentido, é possível afirmar que o PEHE age em instância cotidiana, porém visando uma estratégia maior, que é a garantia da SAN.

Esse raciocínio é explicitado no Mapeamento do Projeto Educando com a Horta Escolar (2010) em que, ao se mencionar a importância de implementar um projeto político pedagógico, ressalta-se a necessidade de contextualizar esse projeto à realidade local, com expectativas de aplicação na vida cotidiana. Tal contextualização objetiva o entendimento por parte da escola de que as atividades oferecidas influenciam em múltiplas dimensões, "integrando saberes que possam formar pessoas conscientes e capazes de discutir e transformar sua história” (PROJETO EDUCANDO COM A HORTA ESCOLAR, 2010, p. 82). E, no que concerne à informação, é possível observar sua importância logo na concepção do projeto, visto que foi adotado um material comunicativo como parte da estratégia na implementação da horta escolar.

Um exemplo da valorização da informação para a cidadania é encontrada no Caderno 1 - “A Horta Escolar dinamizando o currículo da escola.” Por se valer de questões como a educação e o papel do educador, o caderno dedica grande parte de seu conteúdo para refletir

\footnotetext{
${ }^{21}$ A importância da informação está presente, inclusive, no logotipo do projeto, em que se mencionam diversos temas, e um deles é INFORMAÇÃO.
} 
sobre a educação como promotora da cidadania e da educação alimentar, de maneira que forme indivíduos com senso crítico e autonomia nas escolhas alimentares.

Soma-se também o fato de que as tarefas extracurriculares fornecidas no material (discussão sobre filmes que tratam de alimentação, criação de jornal da escola que aborda a horta, entre outros) integram atividades, que trazem o cotidiano para dentro o ambiente escolar.

\section{4) Mídia e alimentação}

Os autores criticam a atuação da mídia na abordagem da alimentação e afirmam que as transformações alimentares se dão, atualmente, pelos meios de comunicação de massa. Estes promovem determinados padrões e regras alimentares pouco acessíveis e condizentes com a realidade nacional. Também relacionam a mídia à tendência de culpabilização do indivíduo sobre sua situação nutricional, à promoção de estereótipos irreais de corpo e beleza, bem como um dos principais elementos que corroboram com a dificuldade de entendimento em torno do conceito de alimentação saudável.

Tais críticas podem ser encontradas principalmente no Caderno 3 - “Alimentação e nutrição: caminhos para uma vida saudável”. Um trecho a ser citado é quando se contestam os padrões e regras de que, para ser saudável, “é preciso gastar mais, comer somente verduras e legumes, consumir somente produtos requintados, difíceis de serem encontrados ou comer apenas alimentos de sabor desagradável” (PROJETO EDUCANDO COM A HORTA ESCOLAR, 2009c, p. 31).

O PEHE não impõe soluções milagrosas ou regras prontas para uma alimentação saudável, mas esclarece que existe, antes do hábito, a cultura alimentar. Pela análise de fontes de informação usadas pelos autores, é possível detectar que tal diretriz é a mesma encontrada no Guia Alimentar (BRASIL, 2006), onde se encontra a explicitação do papel da mídia na legitimação do discurso de que, para ter uma alimentação saudável, é necessário acesso a alimentos importados e/ou industrializados.

O PEHE não se atém apenas às críticas da mídia, mas propõe novas abordagens para o tema. Grande parte da alternativa ao discurso midiático consta no Caderno 3 (Capítulo IV “A Horta como estratégia de mudança da cultura alimentar”): um exemplo de estratégia é dar foco à origem do alimento que chega às mesas, questão largamente discutida por Pollan (2007), e em filmes como Food. Inc. (2008) e Nação Fast Food: uma rede de corrupção (2006) - este último, indicado no Mapeamento do PEHE como referência complementar para alunos e professores. 
Em relação à educação nutricional, o PEHE posiciona-se contrário ao tipo de comunicação que transfere somente para o indivíduo a responsabilidade sobre sua situação nutricional. No Caderno 3, reitera-se a existência de razões mais abrangentes que acarretam a má nutrição, como as condições socioeconômicas e o preço dos alimentos. Tal orientação também é encontrada no Guia Alimentar (BRASIL, 2006), bem como em autores como Pollan (2007) e Costa (2011): todos criticam os programas educativos que enfocam na responsabilização individual para sua situação nutricional, com consequente culpabilização do indivíduo.

Pode-se concluir que, por criticar o papel da mídia e propor outras visões, o PEHE atua como contraponto à visão predominante dentro do campo midiático. Isso pode ser visualizado pelos posicionamentos e fontes adotadas como referência: tal qual o Guia Alimentar (BRASIL, 2006), que adota o alimento como referência, o PEHE separa os grupos de alimentos não por nutrientes, mas por grupos alimentares (grupo dos pães e massas, vegetais e frutas, entre outros). O que demonstra uma preocupação com uma linguagem de fácil entendimento para indivíduos de diversas faixas etárias e de escolaridade, bem como a aplicação prática no cotidiano.

Além disso, vale destacar que, quando se adota o alimento como referência, simultaneamente, critica-se o nutricionismo (POLLAN, 2008), ou seja, a visão científica do alimento, baseada somente em seus nutrientes. Essa crítica pode ser sintetizada no PEHE, no seguinte trecho de seu Mapeamento do Projeto Educando com a Horta Escolar (2010, p. 103):

Conhecer as propriedades nutricionais dos alimentos é importante, mas atividades que permitam aos escolares construir uma visão crítica sobre esses aspectos da alimentação podem conferir maior autonomia e maturidade diante das situações cotidianas, como as escolhas alimentares rotineiras, o consumo consciente e o efeito da mídia/publicidade.

Dessa maneira, é possível afirmar que o PEHE condena a atuação dos meios de comunicação, mas não faz a crítica sem embasamento. Ao contrário, propõe novas maneiras de se compreender essa relação com os alimentos, dando destaque ao entendimento do conceito de cultura alimentar, SAN, DHAA, bem como à proposta de adotar o alimento como referência.

\section{5) Alimento saudável: sentidos e significações}

Ainda que se tenha notado um comprometimento na busca de fontes, sobretudo as de órgãos oficiais, foram detectados alguns pontos negativos no material analisado. Quando se conceitua alimentação saudável, o Caderno 3 utiliza as mesmas referências do Guia Alimentar (BRASIL, 2006), que, por sua vez, baseou suas diretrizes em relatórios da Organização 
Mundial da Saúde e do Ministério da Saúde. Contudo, há praticamente uma cópia do conteúdo, nem sempre colocando as referências ao Guia Alimentar (BRASIL, 2006).

Outro ponto é que fontes de informação e documentos de órgãos oficiais usados, como Guia Alimentar (BRASIL, 2006), FAO e OMS, se autorreferenciam. Tal ocorrência permite que, por um lado, se produza uma linguagem coesa; por outro, cria um discurso que pode ser uniforme e pouco crítico. É possível questionar se a repetição de discursos oficiais também não impede que se tenha conhecimento de outros modelos e estratégias advindos de fontes alternativas, como experiências populares ou de outras entidades.

Também no Caderno 3 (Capítulo V - “Fazendo a horta”), há uma tabela de valores nutricionais dos alimentos, cuja fonte coletada é do site ABC da Saúde, que não é uma fonte oficial e possui fins comerciais. Foi observado que outra fonte utilizada no material, referenciada como dados da Pesquisa Nacional sobre Saúde e Nutrição (PNSN) (PROJETO EDUCANDO COM A HORTA ESCOLAR, 2009c, p. 24), na realidade são dados coletados de sítios da Internet também não oficiais, cujos dados não conferem com documentações do PNPS, consultados para esta pesquisa em fontes eletrônicas e bibliotecas. Ainda com relação a fontes, o material didático possui trechos de jornal, revista ou artigo que aparentam desconexão com o restante do conteúdo.

Esses pontos detectados incidem em duas possibilidades: a) de que o Estado carece de fontes confiáveis, sobretudo no ambiente eletrônico; b) os produtores do material se valeram de conteúdos de fácil acesso e não checaram outras fontes disponíveis.

\section{6) PEHE e a construção da cidadania}

É possível afirmar que o objetivo central do PEHE é disponibilizar uma estratégia de educação nutricional que desencadeie na promoção da cidadania - tema que circunscreve grande parte dos temas elencados.

Mesmo que possua pontos a serem reavaliados, o material didático consegue articular as diferentes dimensões da Segurança Alimentar e Nutricional, ressaltando a importância de se garantir o Direito Humano à Alimentação Adequada e da Soberania Alimentar. O discurso adotado pelo PEHE contesta os modelos de consumo da atualidade, já que a horta é uma possibilidade de resistência, uma forma de politização na prática cotidiana de se produzir o alimento. Além disso, a proposta do PEHE consegue ser uma estratégia de promoção da cidadania e da conscientização do indivíduo para seus direitos como cidadão, e realizar essa estratégia dentro do cotidiano escolar. 
Há uma politização do objeto de estudo, pois demonstra como uma questão de produção de alimento em menor escala, isto é, a horta escolar, pode atribuir significados ambientais, políticos e sociais. O PEHE redefine processos ao integrar, via horta escolar, aspectos que concernem ao corpo, à mente e ao meio ambiente, integração que coincide com os conceitos advindos da Promoção da Saúde e Saúde Coletiva. Dessa maneira, a horta não é considerada meramente uma técnica porque, se fosse assim, somente o Caderno 2 seria necessário, pois é lá que se encontram os procedimentos técnicos da horta.

Outro ponto a ser destacado é o de que o objeto de estudo reforça e difunde grande parte das diretrizes de alimentação elencadas nesta pesquisa, demonstrando ser possível um material comunicativo tratar da questão do alimento sob uma nova abordagem.

Vale mencionar que o interesse para esta pesquisa não é se o Projeto foi viabilizado ou não na prática. Mas, sim, verificar se os conceitos e noções usadas no material didático são, de fato, condizentes com uma abordagem sobre alimentação que fomente a cidadania e seja um contraponto ao discurso midiático dominante. Como essa pesquisa se limita a fazer uma apreciação crítica do material didático, cabe a futuros pesquisadores conhecer se, na prática, o projeto de fato foi concretizado nos municípios participantes.

Por fim, as leituras e releituras do material permitem que se tenha a perspectiva de que o indivíduo em formação que participou do projeto, ao tomar ciência de quais alimentos deve consumir e o que lhe é direito em termos de nutrientes e saúde, poderá requerer os direitos sociais propostos pela Segurança Alimentar e Nutricional. Assim, o saber e a informação para a cidadania lhe fornecerão subsídios para requerer seus direitos de uma alimentação saudável, em quantidade e qualidade suficientes, que respeite o produtor e o meio ambiente. 


\section{Considerações finais}

Partindo do movimento da Promoção da Saúde, a pesquisa objetivou esclarecer dois pontos: quanto a alimentação e, por consequência, a saúde do indivíduo, está interligada a fatores não só biológicos, mas também sociais, econômicos e culturais; e quanto uma alimentação saudável está diretamente ligada ao cumprimento dos direitos humanos e sociais.

Assim, o Direito Humano à Alimentação Adequada (DHAA), uma das premissas da Segurança Alimentar e Nutricional (SAN), constitui-se em um direito de cidadania, ou seja, um direito básico, que deve ser garantido pelo Estado. O DHAA é reflexo das demandas contemporâneas, dos direitos de terceira geração, das minorias e grupos com causas específicas. E, embora se saiba que esses direitos já foram referendados pelos governos do mundo todo, nota-se que a demanda atual se constitui no cumprimento desses direitos.

No que tange aos processos comunicativos, é importante rever modelos de transferência de conhecimento, que continuam a serem usados como metodologia de políticas públicas em saúde. Urge uma formação em SAN para comunicadores, de maneira que, ao abordar o tema, não se tenha em mente somente os aspectos médicos e sanitaristas, que visem ao consumo ou interesses privados, mas, sim, à promoção da cidadania.

Partindo desse pressuposto, a pesquisa visou possibilitar um maior esclarecimento sobre o tema alimentação. E, em consequência, o surgimento de novas propostas de planejamento e avaliação de programas informativos para a promoção da saúde, bem como a revisão de conceitos, transformações de relações e mudanças institucionais.

Isso porque, pela análise do tema, foi possível inferir a ausência de uma estratégia comunicacional e formação na temática, que deveria ser implementada por setores que visam à ampliação dos direitos da cidadania e dos direitos humanos. Essa lacuna se reflete nos conteúdos sobre o assunto: há uma descontextualização do tema, bem como um modelo de discurso pautado em regras fixas, orientações simplistas e pouco alinhadas à realidade de quem busca a informação.

Pensando nisso, as diretrizes em alimentação fornecidas pretendem ampliar o debate e promover novas ações por parte dos elaboradores de políticas públicas, jornalistas e todos os que têm possibilidades de difundir a informação para a cidadania. Contudo, uma hipótese negativa com a divulgação do presente trabalho é se, de fato, a sociedade (ou parte dela) está interessada em alterar o modelo fragmentário no tema da alimentação, e se os segmentos sociais estão plenamente interessados na passagem de uma formação técnica para uma teórica e reflexiva. 
É possível afirmar que o fornecimento de tais diretrizes corresponde a um desdobramento da pesquisa já iniciada por Pollan (2007, 2008, 2010). E, enquanto o autor tratou dos pilares da indústria alimentícia, mídia e governo, voltando suas pontuações para o público geral, esta pesquisa se foca mais em diretrizes específicas para quem vai elaborar políticas públicas comunicacionais ou materiais comunicativos.

Dessa maneira, o objeto de estudo selecionado, o material didático do Projeto Educando com a Horta Escolar procura não só criticar a abordagem midiática sobre o assunto, mas se mostra como um contraponto. O PEHE trata dos aspectos mais amplos em torno do alimento, bem como reforça a importância da informação para que a pessoa adquira juízo de valor e possa decidir e reivindicar como quer que se dê sua alimentação. Dentro dessa perspectiva, a informação é dada de maneira que o indivíduo tenha autonomia de escolha.

Como conclusão, um dos aspectos que se mostram importantes é renunciar à postura de somente criticar a mídia que trata de alimentação, nutrição, saúde e dieta. É necessário também propor novos paradigmas e possibilidades em torno de um tema, a fim de enriquecer a discussão democrática e concretizar as mudanças em nossa realidade. 


\section{Referências bibliográficas}

ABREU, A. A. Jornalismo cidadão. Revista Estudos Históricos, Rio de Janeiro, v. 1, n. 31, p. 25-40, 2003. Disponível em: $<$ http://bibliotecadigital.fgv.br/ojs/index.php/reh/article/view/2185/1324>. Acesso em: 19 jun. 2011.

ALIMENTAÇÃO agora é um direito garantido na Constituição. Rio de Janeiro: Actionaid, 04 fev. 2010. Disponível em: <http://187.45.205.122/Default.aspx?tabid=1096>. Acesso em: 01 set. 2012.

AMARAL, P. Coma e Engorde! Um guia prático para todos aqueles que desejam alimentarse cientificamente e gozar boa saúde. São Paulo: Brasiliense, 1958. 233 p.

ARAÚJO, I. S. Mercado simbólico: um modelo de comunicação para políticas públicas. Interface (Botucatu), Botucatu, v. 8, n. 14, p. 165-178, fev. 2004. Disponível em: <http://www.scielo.br/pdf/icse/v8n14/v8n14a09.pdf>. Acesso em: 01 jun. 2012.

ARAÚJO, I. S.; CARDOSO, J. M. Comunicação e saúde. Rio de Janeiro: FIOCRUZ, 2007. 149 p. (Coleção Temas em Saúde).

ARENDT, H. A mentira na política: considerações sobre os documentos do Pentágono. In:__ Crises da República. São Paulo: Perspectiva, 1973. p. 9-48.

BOBBIO, N. A era dos direitos. Rio de Janeiro: Campus, 1992. 217 p.

BÓGUS, C. M.; WESTPHAL, M. F. Participação social e cidadania em movimentos por cidades saudáveis. In: FERNANDEZ, J. C. A.; MENDES, R. (Org.). Promoção da saúde e gestão local. São Paulo: CEPEDOC, 2007. p. 39-55.

BUENO, W. C. Comunicação para a saúde: uma experiência brasileira. São Paulo: Plêiade; Amparo: Unimed, 1996. 180 p.

BRASIL. Lei $\mathrm{n}^{0}$ 8.080, de 19 de setembro de 1990. Dispõe sobre as condições para a promoção, proteção e recuperação da saúde, a organização e o funcionamento dos serviços correspondentes e dá outras providências. Diário Oficial da União, Brasília, DF, 20 set. 1990. Disponível em: <http://www.planalto.gov.br/ccivil_03/leis/l8080.htm>. Acesso em: 08 jun. 2011.

Lei $\mathrm{n}^{0}$ 11.346, de 15 de setembro de 2006. Cria o Sistema Nacional de Segurança Alimentar e Nutricional - SISAN com vistas em assegurar o direito humano à alimentação adequada e dá outras providências. Diário Oficial da União, Brasília, DF, 18 set. 2006. Disponível em: <http://www4.planalto.gov.br/consea/legislacao/lei-no-11-346-de-15-desetembro-de-2006>. Acesso em: 03 jun. 2011.

BRASIL. Ministério da Saúde. Secretaria de Atenção à Saúde. Departamento de Atenção Básica. Política Nacional de Alimentação e Nutrição. 2. ed. rev. Brasília: Ministério da Saúde, 2003. 48 p. Disponível em: <http://189.28.128.100/nutricao/docs/geral/pnan.pdf>. Acesso em: 26 nov. 2011. (Série B. Textos Básicos de Saúde).

O que é uma alimentação saudável? Considerações sobre o conceito, princípios e características: uma abordagem ampliada. Brasília: Ministério da Saúde, mai. 2005. 5 p. Disponível em: <http://189.28.128.100/nutricao/docs/geral/oQueEAlimentacaoSaudavel.pdf>. Acesso em: 26 mai. 2011. 
BRASIL. Ministério da Saúde. Secretaria de Atenção à Saúde. Coordenação-Geral da Política de Alimentação e Nutrição. Guia alimentar para a população brasileira: promovendo a alimentação saudável. Brasília: Ministério da Saúde, 2006. 210 p. Disponível em: $<$ http://189.28.128.100/nutricao/docs/geral/guia_alimentar_conteudo.pdf $>$. Acesso em: 16 jul. 2011. (Série A. Normas e Manuais Técnicos).

BRASIL. Ministério da Saúde. Agência Nacional de Vigilância Sanitária. Resolução - RDC $\mathrm{N}^{0}$ 24, de 15 de junho de 2010. Resolução da Diretoria Colegiada da Agência Nacional de Vigilância Sanitária. Diário Oficial da União, 15 jun. 2010. Disponível em: $<$ http://www2.rio.rj.gov.br/vigilanciasanitaria/legislacao/rdc024_15062010.pdf > . Acesso em: 03 jun. 2011.

CARVALHO, J. M. Cidadania no Brasil: tipos e percursos. Revista Estudos Históricos, Rio de Janeiro, v. 9, n. 18, p. 337-359, 1996. Disponível em: $<$ http://bibliotecadigital.fgv.br/ojs/index.php/reh/article/view/2029/1168>. Acesso em: 19 jun. 2011.

CONSELHO NACIONAL DE SEGURANÇA ALIMENTAR E NUTRICIONAL (CONSEA). Construção do Sistema e da Política Nacional de Segurança Alimentar e Nutricional: a experiência brasileira. Brasília: CONSEA, 2009. 90 p. Disponível em: $<$ https://www.fao.org.br/download/Seguranca_Alimentar_Portugues.pdf $>$. Acesso em: 12 nov. 2011.

A segurança alimentar e nutricional e o direito humano à alimentação adequada no Brasil: indicadores e monitoramento da Constituição de 1988 aos dias atuais. Brasília: CONSEA, nov. 2010. 2842 p. Disponível em: $<$ http://www2.planalto.gov.br/consea/biblioteca/publicacoes/a-seguranca-alimentar-enutricional-e-o-direito-humano-a-alimentacao-adequada-no-brasil>. Acesso em: 29 dez. 2012.

COSTA, C. G. A. Segurança alimentar e nutricional: significados e apropriações. São Paulo: Annablume, 2011. 329 p.

CUSTÓDIO, M. B. Política Nacional de Segurança Alimentar e Nutricional no Brasil: arranjo institucional e alocação de recursos. 2009. 326 f. Tese (Doutorado em Nutrição Humana Aplicada) - Faculdade de Ciências Farmacêuticas, Universidade de São Paulo, São Paulo, 2009. Disponível em: <http://www.teses.usp.br/teses/disponiveis/89/89131/tde03032010-101411/publico/TESE_MARTA_BATTAGLIA_CUSTODIO.pdf $>$. Acesso em: 12 ago. 2011.

DAGNINO, E. ¿Sociedade civil, participação e cidadania: de que estamos falando? In: MATO, D. (Coord.). Políticas de ciudadanía y sociedad civil en tiempos de globalización. Caracas: FACES; Universidad Central de Venezuela, 2004. p. 95-110. Disponível em: <http://www.globalcult.org.ve/pub/Rocky/Libro2/Dagnino.pdf $>$. Acesso em: 15 jul. 2011.

DEPARTAMENTO DE INFORMÁTICA DO SUS (DATASUS).O DATASUS. Disponível em: <http://www2.datasus.gov.br/DATASUS/index.php?area=01>. Acesso em: 7 dez. 2011.

ECO, U. Como se faz uma tese. 14. ed. São Paulo: Perspectiva, 1996. 170 p.

FOOD AGRICULTURE ORGANIZATION OF UNITED NATIONS (FAO). Declaração de Roma sobre a Segurança Alimentar Mundial e Plano de Acção da Cimeira Mundial da Alimentação - World Summit. Roma: FAO, 13-17 nov. 1996. Disponível em: <http://www.fao.org/docrep/003/W3613P/W3613P00.htm> Acesso em: 03 jun. 2011.

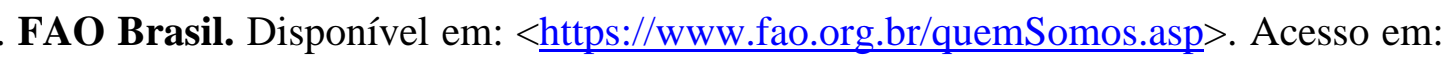
12 nov. 2011. 
FERNANDEZ, J. C. A.; MENDES, R. Gestão local e políticas públicas para a qualidade de vida. In:

Promoção da saúde e gestão local. São Paulo: CEPEDOC, 2007. p. 25-38.

GENTILLI, V. Democracia de massas: jornalismo e cidadania - estudo sobre as sociedades contemporâneas e o direito dos cidadãos à informação. Porto Alegre: EDIPUCRS, 2005. 180 p.

GIL, A. C. Como elaborar projetos de pesquisa. 5 ed. São Paulo: Atlas, 2010. 184 p.

HELLER, A. O cotidiano e a história. 8. ed. Rio de Janeiro: Paz e Terra, 2008. 158 p.

HAUTE-COMMISSARIAT POUR LE DROIT DE L'HOMME (HCDH). Pacte international relatif aux droits économiques, sociaux et culturels. Genève, 16 de dezembro de 1966. Disponível em: <http://www2.ohchr.org/french/law/cescr.htm>. Acesso em: 27 jun. 2011.

HIRSCHMAN, A. O. A retórica da intransigência: perversidade, futilidade, ameaça. São Paulo: Companhia das Letras, 1992. 151 p.

INSTITUTO BRASILEIRO DE GEOGRAFIA E ESTATÍSTICA (IBGE). Pesquisa de orçamentos familiares 2008-2009: antropometria, estado nutricional de crianças, adolescentes e adultos no Brasil. Brasília: IBGE, 2010a. Disponível em:

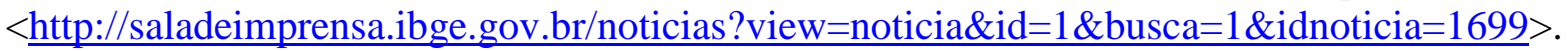
Acesso em: 3 set. 2011.

Pesquisa Nacional por Amostra de Domicílios (PNAD): Segurança Alimentar 2004/2009. Brasília: IBGE, 2010b. 183 p. Disponível em: <http://www.ibge.gov.br/home/estatistica/populacao/seguranca_alimentar_2004_2009/pnadal imentar.pdf >. Acesso em: 15 abr. 2011.

INSTITUTO DE PESQUISA ECONÔMICA APLICADA (IPEA). O IPEA pensa e pesquisa o Brasil. Brasília: IPEA, 2010. 19 p. Disponível em: $<$ http://www.ipea.gov.br/portal/images/stories/PDFs/folder_institucional_jul_2010_v8_portug ues.pdf $>$. Acesso em: 05 dez. 2011.

INSTITUTO NACIONAL DE SAÚDE E NUTRIÇÃO. Pesquisa Nacional sobre Saúde e Nutrição - PNSN: resultados preliminares. 2. ed. Brasília: INAN, 1990. 33 p.

JACOBSON, M. F.; NESTLE, M. Halting the obesity epidemic: a public health policy approach. Public Health Reports, v. 115, 2000, p. 12-24. Disponível em: $<$ http://www.cspinet.org/reports/obesity.pdf $>$. Acesso em: 6 jul. 2012.

KATZ, E.; LAZARSFELD, P. Personal influence: the part played by people in the flow of mass communication. Nova York: Free Press, 1955. 400 p.

KOSHIYAMA, A. M. Jornalismo, ética e política: Gramsci e a escolha de Claudio Abramo. In: LOPES, M. I. V.; BUONANNO, M. (Org.). Comunicação social e ética: Colóquio Brasil - Itália. São Paulo: INTERCOM, 2005.

KUCINSKI, B. Jornalismo, saúde e cidadania. Interface: Comunicação, Saúde, Educação, Botucatu, v. 4, n. 6, 2000, p. 181-186. Disponível em: <http://www.redalyc.org/articulo.oa?id=180114089025 > . Acesso em: 12 set. 2012.

LALONDE, M. A new perspective on the health of canadians: a working document. Ottawa: Government of Canada, 1974. 76 p. Disponível em: <http://www.hcsc.gc.ca/hcs-sss/alt_formats/hpb-dgps/pdf/pubs/1974-lalonde/lalonde-eng.pdf>. Acesso em: 12 mai. 2013. 
LIMA, V. A. Políticas de mídia e cidadania. In: XIV JORNADA MULTIDISCIPLINAR MÍDIA E CIDADANIA, 14., 2012, Bauru. Anais... Bauru: UNESP, 2012.

MARSHALL, T. H. Cidadania, classe social e status. Rio de Janeiro: Zahar, 1963.

MARTÍN-BARBERO, J. Dos meios às mediações: comunicação, cultura e hegemonia. Rio de Janeiro: UFRJ, 1997. 360 p.

MANZINI-COVRE, M. L. O que é cidadania. São Paulo: Brasiliense, 1996. 78 p.

MINAYO, M. C. S. O desafio do conhecimento: pesquisa qualitativa em saúde. São Paulo: Hucitec; ABRASCO, 1992. 269 p.

ORTEGA y GASSET, J. A rebelião das massas. São Paulo: Martins Fontes, 1987. 258 p.

PELIANO, A. M. T. M. (Coord.). O mapa da fome: subsídios à formulação de uma política de segurança alimentar. Brasília: IPEA, 1993. 25 p. (IPEA. Documento de Política, 14).

PEREIRA, G.; CASTRO, I. Considerações sobre o plano de combate à fome e à miséria. Caderno de Saúde Pública, Rio de Janeiro, v. 27 (supl. 1), p. 106-113, 1993. Disponível em: <www.scielo.br/pdf/csp/v9s1/12.pdf> Acesso em: 28 out. 2011.

PINHEIRO, A. R. O. Análise histórica do processo de formulação da Política Nacional de Segurança Alimentar e Nutricional (2003-2006): atores, ideias, interesses e instituições na construção de consenso político. 2009. 234 f. Tese (Doutorado em Política Social) Instituto de Ciências Humanas, Universidade de Brasília, Brasília, 2009.

POLLAN, M. O dilema do onívoro: uma história natural de quatro refeições. Rio de Janeiro: Intrínseca, 2007. 479 p.

Em defesa da comida: um manifesto. Rio de Janeiro: Intrínseca, 2008. 271 p.

2010. 160 p.

Regras da comida: um manual da sabedoria alimentar. Rio de Janeiro: Intrínseca,

PROJETO EDUCANDO COM A HORTA ESCOLAR. A Horta Escolar Dinamizando o Currículo da Escola. Caderno 1. 3. ed. Brasília, 2009a.

PROJETO EDUCANDO COM A HORTA ESCOLAR. Orientações para Implantação e Implementação da Horta Escolar. Caderno 2. 3. ed. Brasília, 2009 b.

PROJETO EDUCANDO COM A HORTA ESCOLAR. Alimentação e Nutrição Caminhos para Uma Vida Saudável. Caderno 3. 2. ed. Brasília, 2009c.

PROJETO EDUCANDO COM A HORTA ESCOLAR. Aprendendo com a horta. Caderno 4 - volumes 1 e 2. Brasília: PEHE, 2009d.

PROJETO EDUCANDO COM A HORTA ESCOLAR. Mapeamento do processo: implantação e implementação do projeto Educando com a Horta Escolar. Brasília, 2010.

PROJETO EDUCANDO COM A HORTA ESCOLAR. Vídeo Institucional. 1 CD-ROM. PROJETO EDUCANDO COM A HORTA ESCOLAR. Vídeo Metodológico. 2 CD-ROM.

REIMBERG, C. O. Comunicação, educação e saúde: a ação da Pastoral da Criança para a cidadania na Arquidiocese de São Paulo. 2009. 304 f. Dissertação (Mestrado em Ciências da Comunicação) - Escola de Comunicações e Artes, Universidade de São Paulo, São Paulo, 2009. Disponível em: <http://www.teses.usp.br/teses/disponiveis/27/27154/tde-21102010101739/publico/5065645.pdf>. Acesso em: 26 ago. 2010. 
SAES, D. A. M. Cidadania e capitalismo: uma crítica à concepção liberal de cidadania. São Paulo: Instituto de Estudos Avançados da USP, 2000. 49 p. (Série Especial - Coleção Documentos, 8).

SCHLOSSER, E. País fast food: o lado nocivo da comida norte-americana. São Paulo: Ática, 2002. $405 \mathrm{p}$.

SEN, A. Desenvolvimento humano e IDH. PNUD - Programa das Nações Unidas para o Desenvolvimento, $1999 . \quad$ Disponível em: <http://www.pnud.org.br/IDH/DH.aspx?indiceAccordion=0 > . Acesso em: 12 dez. 2011.

SÍCOLI, J. L.; NASCIMENTO, P. R. Health promotion: concepts, principles and practice. Interface - Comunicação, Saúde, Educação, Botucatu, v. 7, n. 12, p. 91-112, 2003. Disponível em: <http://www.scielo.br/pdf/icse/v7n12/v7n12a07.pdf>. Acesso em: 8 ago. 2011.

TRINDADE, E. Um olhar exploratório sobre o consumo e a midiatização das marcas de alimentos nas vidas de algumas famílias. Matrizes, São Paulo, v. 6, n. 1-2, jul./dez. 2012, p. 77-96. Disponível em: $<$ http://www.matrizes.usp.br/index.php/matrizes/article/view/344/pdf > . Acesso em: 27 fev. 2013.

VALENTE, F. L. S. Promoção do Direito Humano à Alimentação Adequada (DHAA). In: 32 $2^{\mathrm{a}}$ SESSÃO ANUAL DO COMITÊ PERMANENTE DE NUTRIÇÃO DA ONU. Brasília: ONU, $2005 . \quad 9 \quad$ p. $\quad$ Disponível em: $\quad$ http://www.actuaracd.org/uploads/5/6/8/7/5687387/flavio_valente_dhaa_promocao_do_direito_humano_a_alim entacao_adequada.pdf $>$. Acesso em: 10 dez. 2011.

WESTPHAL, M. F. Promoção da Saúde e a qualidade de vida. In: FERNANDEZ, J. C. A.; MENDES, R. (Org.). Promoção da saúde e gestão local. São Paulo: CEPEDOC, 2007, p. 6-24.

WORLD HEALTH ORGANIZATION. About WHO. Disponível em: <http://www.who.int/about/en/index.html> Acesso em: 03 dez. 2011. 


\section{Anexos}

Em ordem alfabética, segue listagem de termos e siglas de entidades, marcos e instituições relativas ao tema da alimentação, com breve explicação de cada um deles.

- Comentário Geral n 12 do Comitê de Direitos Econômicos, Sociais e Culturais da ONU (1999):

O Comitê de Direitos Econômicos, Sociais e Culturais da ONU elaborou, em 1999, o Comentário Geral $\mathrm{n}^{\circ}$ 12, com a finalidade de esclarecer o conteúdo do Direito Humano à Alimentação Adequada, bem como fornecer aos governos as diretrizes para que o referido direito seja operacionalizado. O esclarecimento foi solicitado pelos chefes de governo e de Estado durante a Cúpula Mundial da Alimentação, que aconteceu em Roma, em 1996. (VALENTE, 2005, p. 3).

O Comentário apresenta as seguintes estratégias:

a. Articulação das políticas, programas e ações públicas relevantes;

b. Definição participativa de:

i. Indicadores

ii. Metas

iii. Prazos

iv. Recursos alocados

c. Estabelecimento de mecanismos de Monitoramento e Avaliação (tanto de SAN como de DH);

d. Consolidação de uma Lei Orgânica de promoção do DHA no contexto da Segurança Alimentar e Nutricional (VALENTE, 2005, p. 3).

O Comentário salienta que os Estados também devem operacionalizar o Direito Humano à Alimentação pensando concomitantemente na promoção dos outros princípios básicos dos Direitos Humanos, isto é, universalidade, não discriminação, indivisibilidade, participação, entre outros (VALENTE, 2005).

Para tanto, é obrigação do Estado:

a. Desenvolver um processo intenso e continuado de capacitação em serviço dos gestores e funcionários públicos;

b. Desenvolver mecanismos públicos de informação sobre os Direitos Humanos para a população em geral;

c. Promover a participação qualificada (com capacitação) da sociedade civil em organismos de monitoramento;

d. Garantir recursos públicos para instituições de monitoramento que garantam sua independência (VALENTE, 2005, p. 4). 


\section{- I Conferência Nacional de Alimentação e Nutrição (ICNAN):}

Ocorrida em 1986, o ICNAN foi organizado pela sociedade civil para maior mobilização em torno de temas como segurança alimentar e qualitativo nutricional (CONSEA, 2009, p. 24). Neste ano, ocorreu como parte do processo da $8^{\circ}$ Conferência Nacional de Saúde e contou com a participação de representantes governamentais e não governamentais (IPEA, 2010).

Na ICNAN, o conceito inicial de segurança alimentar foi ampliado ao incorporar, às questões da produção agrícola e do abastecimento, outras esferas - como acesso e qualidade dos alimentos e carências nutricionais. Nesta conferência, a alimentação foi colocada como um direito, e, para isso, surgiu a proposta de se criar um conselho nacional de alimentação e nutrição vinculado ao Ministério da Saúde, bem como a elaboração de um sistema de segurança alimentar e nutricional sob coordenação do Ministério do Planejamento. As duas propostas se dariam com a participação da sociedade civil, conforme aponta estudo do IPEA (2010, p. 12).

A implantação dessa estrutura fora proposta também aos Estados, com a finalidade de se ter uma garantia maior de acesso aos alimentos em quantidade de qualidade suficientes. No entanto, poucos foram os resultados concretos da ICNAN, e o assunto voltou à pauta somente após o início dos anos 1990. (IPEA, 2010, p. 12).

Vale destacar também as edições posteriores, como a II Conferência Nacional de Segurança Alimentar e Nutricional, ocorrida em 2004, em Olinda. Nesta conferência, foi criada a Comissão Permanente para o Direito Humano à Alimentação Adequada, que se responsabilizaria pela análise de políticas e programas públicos, sempre sob a diretriz da promoção do DHAA, e também por repassar as recomendações aos gestores públicos (VALENTE, 2005, p. 8).

A III CNAN, realizada em 2007, em Fortaleza, definiu a SAN “como objetivo estratégico para o desenvolvimento com abrangência intersetorial, que se orienta pelos princípios do Direito Humano à Alimentação Adequada (DHAA) e da Soberania Alimentar” publicado pelo CONSEA (2007 citado por COSTA, 2011, p. 29). Já a IV CNAN ocorreu em novembro de 2011, em Salvador, sob o tema: “Alimentação Adequada e Saudável: direito de todos”, com cerca de 2 mil participantes. 


\section{- Conselho Nacional de Segurança Alimentar (CONSEA):}

O Conselho Nacional de Segurança Alimentar e Nutricional (CONSEA) é um órgão criado em 1993 e que hoje é o principal articulador nacional para a questão da segurança alimentar. O CONSEA (2010, p. 36) define segurança alimentar como

O direito de todos ao acesso regular e permanente a alimentos de qualidade, em quantidade suficiente, sem comprometer o acesso a outras necessidades essenciais, tendo como base em práticas alimentares promotoras de saúde, que respeitem a diversidade cultural e que sejam social,econômica e ambientalmente sustentáveis.

Seus princípios norteadores são:

- Universalidade e equidade no acesso a uma alimentação adequada;

- Participação social em políticas intersetoriais e transparência;

- Respeito à soberania alimentar e garantia do direito humano à alimentação adequada e sua exigibilidade;

- Produção camponesa e familiar como componente essencial na construção da soberania e segurança alimentar e nutricional;

- Solidariedade, complementaridade e cooperação entre os países e atores sociais envolvidos. (CONSEA, 2010)

Para o CONSEA, a Segurança Alimentar e Nutricional (SAN) é um objetivo permanente para que se realizem políticas públicas e se efetive os princípios do Direito Humano à Alimentação Adequada (DHAA) e da Soberania Alimentar (CONSEA, 2009, p. 14). Soberania Alimentar consiste no direito de a sociedade definir como se darão suas políticas de produção, distribuição e consumo de alimentos, de maneira que se respeite o meio ambiente, a agricultura familiar e a preservação dos hábitos alimentares específicos de cada região (CONSEA, 2009) ${ }^{22}$. O CONSEA enquanto órgão tem uma sólida base de sustentação, pois entre seus membros constam movimentos e entidades que militam na área de alimentação e nutrição, que “[...] compõe redes associativas reconhecidas como fóruns importantes das discussões e proposições para a área” (COSTA, 2011, p. 17).

O CONSEA também se vale da alimentação adequada como um direito humano, reconhecido no Pacto Internacional de Direitos Humanos, Econômicos, Sociais e Culturais (PIDESC), de 1966, do qual o Brasil é signatário (COSTA, 2011, p. 111).

No período de 2004-2007, o órgão teve destaque na construção da agenda sobre SAN, uma vez que foi o principal articulador entre governo e sociedade civil para elaboração de propostas e diretrizes no que concerne a assuntos relacionados ao alimento e à alimentação (COSTA, 2011, p. 32), sendo responsável pela I Conferência Nacional de Alimentação e Nutrição (CNAN).

\footnotetext{
${ }^{22}$ O Direito Humano à Alimentação Adequada (DHAA) será explicado nos tópicos seguintes.
} 


\section{- Direito Humano à Alimentação Adequada (DHAA):}

A Declaração Universal dos Direitos Humanos (DUDH) se deu em 1948, após muitas lutas dos povos oprimidos e discriminados, que ainda estavam sob impacto dos atos cometidos pelo Estado Alemão Nazista. E, para operacionalizar os Direitos Humanos previstos pela DUHU, em 1966 foram elaborados dois Pactos Internacionais: o Pacto Internacional dos Direitos Civis e Políticos (DCP) e o Pacto Internacional dos Direitos Econômicos, Sociais e Culturais (PIDESC), tendo este último incluído o Direito Humano à Alimentação Adequada (DHAA) conforme aponta Valente (2005, p. 1).

A Alimentação é um Direito Humano, previsto na Declaração Universal dos Direitos Humanos e reafirmado no artigo 11 do Pacto Internacional sobre Direitos Econômicos, Sociais e Culturais ${ }^{23}$. Por direito à alimentação entende-se como o direito de estar livre da fome e da má nutrição e do pleno direito à alimentação adequada, sendo dever do poder público "respeitar, proteger, promover e prover, além de monitorar e avaliar a realização desse direito, bem como garantir os mecanismos para sua exigibilidade” (CONSEA, 2009, p. 36).

O Pacto fora aberto a adesões em 1966 e passou a vigorar em 1976 - no Brasil, entrou no ordenamento jurídico em 1991. Vale destacar os seguintes pontos do artigo 11:

1. Os Estados membros que aderem ao presente pacto reconhecem o direito de toda pessoa a um nível de vida suficiente para ela e sua família, incluindo alimentação, vestuário e abrigo suficientes, bem como uma melhoria contínua de sua condição de vida. Os Estados membros tomarão medidas para assegurar a realização deste direito e reconhecem a importância essencial de uma cooperação internacional de forma livre e consensual para este efeito.

2. Os Estados membros, pelo presente pacto, que reconhecem o direito fundamental de toda pessoa de estar livre da fome, adotarão, individualmente e por meio de cooperação internacional, as medidas necessárias, incluindo programas concretos: a) para melhorar os métodos de produção, de conservação e distribuição de porções alimentares pela plena utilização dos conhecimentos técnicos e científicos, para a difusão de princípios de educação nutricional e para o desenvolvimento ou a reforma de regimes agrários, de modo assegurar ao máximo a valorização e a utilização dos recursos naturais; b) para assegurar uma distribuição equitativa dos recursos alimentares mundiais com relação às necessidades, tendo em conta os problemas que se colocam tanto aos países importadores quanto aos países exportadores de alimentos. (HAUTE-COMMISSARIAT POUR LE DROIT DE L’HOMME (1966 citado por CUSTÓDIO, 2009, p. 31).

Sendo o Brasil signatário deste pacto, é obrigação que o Estado cumpra as regulamentações previstas - não só diante de seus habitantes como de toda a comunidade

\footnotetext{
${ }^{23}$ Um dos principais articuladores desse direito foi elaborado a partir do estudo feito pelo então Relator Especial da ONU, Asbjorn Eide, em 1987, cujas contribuições levaram às bases para a relatoria do Pacto Internacional dos Direitos Econômicos, Sociais e Culturais (PIDESC). (VALENTE, 2005, p. 2).
} 
internacional - por meio de, principalmente, políticas públicas e programas públicos que visem o Direito à Alimentação Adequada (VALENTE, 2005, p. 2).

\section{- Índice de Desenvolvimento Humano (IDH):}

O Índice de Desenvolvimento Humano (IDH) é baseado no conceito de Desenvolvimento Humano e no Relatório de Desenvolvimento Humano, de publicação anual. O Desenvolvimento Humano parte da ideia de que o avanço de uma população não se deve somente ao avanço econômico, e sim a outras características que influenciam a qualidade de vida, como sociais, culturais e políticas.

O IDH foi publicado pela primeira vez em 1990 e criado por Mahbub ul Haq com a colaboração do economista indiano Amartya Sen, ganhador do Prêmio Nobel de Economia de 1998 (SEN, 1999). Esse índice é um contraponto ao Produto Interno Bruto (PIB), indicador que considera apenas o desenvolvimento econômico, visto que o IDH pretende mensurar o desenvolvimento humano. Para isso, leva em conta não só o PIB per capita, mas também outros dois indicadores: longevidade e educação, sendo que os três componentes têm o mesmo peso na mensuração, que varia de zero a um.

As metodologias de cada indicador seguem o seguinte padrão: para considerar o PIB, há um cálculo com base do poder de compra da moeda de cada país; a educação é medida pelo índice de analfabetismo e a taxa de matrícula em todos os níveis de ensino; e a longevidade é calculada pela expectativa de vida ao nascer (SEN, 1999).

O IDH é considerado uma referência mundial, sendo empregado nos Objetivos de Desenvolvimento do Milênio das Nações Unidas. No Brasil, os dados são utilizados pelo governo federal.

\section{- Lei 11.346 - que cria o Sistema Nacional de Segurança Alimentar (SISAN):}

A Lei Orgânica da SAN - Lei $n^{0}$ 11.346, elaborada em 2006 juntamente com a participação do governo e da sociedade civil, conforme indica o documento (BRASIL (2006 citado por CONSEA, 2010, p. 36), e objetiva a inclusão do direito humano à alimentação na Constituição (ALIMENTAÇÃO..., 2010). Essa lei cria o Sistema Nacional de Segurança Alimentar (SISAN), cuja finalidade é assegurar o direito humano à alimentação adequada. A lei estabelece que "o poder público, com a participação da sociedade civil organizada, formule e implementem políticas, planos, programas e ações que visem a garantia desse direito” (PROJETO EDUCANDO COM A HORTA ESCOLAR, 2009a, p. 18). 
O SISAN “deverá ser capaz de articular e promover as relações gerenciais entre todos os entes federados, sendo que todos devem ter como meta comum a realização plena do DHAA” (CONSEA, 2010, p. 24).

\section{- Mapa da Fome - Instituto de Pesquisa e Estatística Aplicada (IPEA):}

O Instituto de Pesquisa e Estatística Aplicada (IPEA), criado em 1964, tem como premissas a disseminação do conhecimento, o planejamento estratégico e permitir que se tenha uma melhor avaliação das políticas públicas, por meio da realização de estudos e pesquisas. O IPEA também fornece apoio técnico e institucional ao governo e, à sociedade, oferece elementos para superar o subdesenvolvimento.

A partir de 2007, passou a ser vinculado à Secretaria de Assuntos Estratégicos da Presidência da República, sendo uma fundação pública federal. Os trabalhos do instituto chegam por meio de publicações, seminários, assessorias, cursos e divulgações nos meios de comunicação (IPEA, 2010, p. 3).

O IPEA é responsável pela organização do documento "Mapa da Fome”, publicado durante a gestão do Governo Itamar Franco, em 1993 (PELIANO, 1993). O documento revelava a dimensão da fome no país, sendo o CONSEA o protagonista nas ações para reverter os dados divulgados. A partir dessa articulação, em abril de 1993, fora elaborado o plano de Combate à Fome e a Miséria, com um conjunto de compromissos e ações assumidos pelo governo a respeito do assunto (PINHEIRO, 2009, p. 94).

\section{- Organização Mundial de Saúde (OMS):}

A Organização Mundial de Saúde (OMS) é a autoridade que dirige e coordena a questão da saúde juntamente com o sistema das Organizações das Nações Unidas (ONU). É responsável pela liderança global em assuntos de saúde, moldando a agenda de pesquisa em saúde, estabelecendo normas e padrões, articulando as opções políticas baseadas em evidências, providenciando suporte técnico a países e monitorando e avaliando as tendências em saúde (WORLD HEALTH ORGANIZATION, 2011).

A OMS consolidou-se no dia 7 de abril de 1948 - data conhecida como Dia Mundial da Saúde. No que concerne ao tema estudado para este artigo, a OMS menciona explicitamente a Segurança Alimentar e Nutricional (SAN) no documento “[...] estratégia global para a Promoção da Alimentação Saudável, Atividade Física e Saúde” (COSTA, 2011, p. 19), lançado em 2004 e que tem como objetivo, segundo Costa (2011), de divulgar um 
conjunto de recomendações para as políticas de saúde, agricultura e desenvolvimento social dos países.

Os principais objetivos da Estratégia Global são:

1) reduzir fatores de risco para DCNT por meio da ação em saúde pública e promoção da saúde e medidas preventivas; 2) aumentar a atenção e conhecimento sobre alimentação; 3) encorajar o desenvolvimento, fortalecimento e implementação de políticas e planos de ação em nível global, regional, nacional e comunitário que sejam sustentáveis, incluindo a sociedade civil, setor privado e a mídia; 4) monitorar dados científicos e influências-chave na alimentação e atividade física e fortalecer os recursos humanos necessários para qualificar e manter a saúde nesse domínio. (OMS, (2004 citado por BRASIL, 2005, p. 18).

A estratégia da OMS contempla também a importância da "provisão da informação adequada aos consumidores, por meio de iniciativas vinculadas à educação, publicidade, rotulagem, legislações de saúde, e enfatiza a necessidade de garantia de articulação intersetorial de políticas nacionais de saúde, educação, agricultura e alimentação” (BRASIL, 2005, p. 120).

\section{- Organização das Nações Unidas para a Agricultura e a Alimentação (FAO):}

O dia 16 de outubro de 1945, Dia Mundial da Alimentação, é marcado pela criação da Organização das Nações Unidas para Agricultura e a Alimentação (FAO). A FAO tem sede em Roma, na Itália, e sua principal função é atuar como um fórum neutro entre países, para que possam discutir estratégias e políticas no sentido de combater a fome e efetivar as diretrizes da segurança alimentar. A FAO considera que intervenções no comportamento alimentar são urgentes e possuem potencial para contribuir com o desenvolvimento social e econômico de um país (PROJETO EDUCANDO COM A HORTA ESCOLAR, 2010, p. 101). A organização conta com 191 países membros, mais a União Europeia. No Brasil, o escritório foi criado em 1979 e, em 2011, José Graziano foi nomeado diretor-geral da FAO.

Sua principal atuação é nas áreas rurais, em que se concentram 70\% da população em situação de fome no mundo. Além disso, a FAO se constitui em fonte de informações nos seguintes assuntos: atividades agrícolas, florestais e pesqueiras, pensando na nutrição, desenvolvimento sustentável e agricultura, de forma de amplie o acesso aos alimentos (FAO, 2011).

- Pesquisa Nacional sobre Saúde e Nutrição (PNSN) - 2005:

A Pesquisa Nacional sobre Saúde e Nutrição (PNSN, 2005) tem como premissa analisar domicílios e registrar o peso e altura dos brasileiros. Os dados gerados permitem a formulação de diagnósticos populacionais de áreas urbanas e rurais das cinco macrorregiões 
brasileiras.

A primeira edição da PNSN se deu em 1989 / 1990 (INAN, 1990) e foi realizada pelo Instituto Nacional de Alimentação e Nutrição (INAN), com a colaboração do Instituto de Planejamento de Gestão Governamental (IPLAN) e Instituto Brasileiro de Geografia e Estatística (IBGE). Nesta primeira edição, foram analisados 17.920 domicílios e registrados o peso e altura de 62 mil pessoas entrevistadas (INAN, 1990).

\section{- Plano de Combate à Fome e à Miséria:}

Evidenciado no Mapa da Fome, que foi elaborado pelo Instituto de Pesquisa Econômica Aplicada (IPEA), o governo usou os subsídios fornecidos para elaborar o "Plano de Combate à Fome e à Miséria - Princípios, Prioridades e Mapa das Ações do Governo”. O objetivo era sistematizar, em diversos ministérios, propostas de intervenção para erradicar a fome e a miséria (PEREIRA; CASTRO, 1993, p. 106).

O Plano apontou as seguintes prioridades pelo Brasil (1991 citado por PEREIRA; CASTRO, 1993, p. 107): “[...] (a) recuperar crianças desnutridas e reduzir a prevalência das diversas formas de desnutrição e (b) "consolidar e assegurar a prestação de ações básicas de saúde, em observância aos princípios do Sistema Único de Saúde”.

O programa se iniciou com a campanha “Leite é Saúde”, desenvolvida pelo Sistema Único de Saúde (SUS), que visa atender crianças menores de 2 anos e gestantes de risco nutricional. À época, a medida foi vista com ressalvas, por ter sido a única intervenção prática adotada para o Plano (BRASIL, 1991).

\section{- Política Nacional de Alimentação e Nutrição (PNAN):}

Homologado em 1999 e ratificado em 2003, a Política Nacional de Alimentação e Nutrição (BRASIL, 2003) tem como objetivo “contribuir com o conjunto de políticas de governo voltadas à concretização do direito humano universal à alimentação e nutrição adequadas e à garantia da Segurança Alimentar e Nutricional da população” (BRASIL, 2006, p. 16). Seu princípio fundamental é o alimento como direito humano e a segurança alimentar e nutricional, garantindo acesso à alimentação adequada, suficiente e segura, sendo a intersetorialidade um elemento-chave para promoção da alimentação saudável (COSTA, 2011, p. 104-105).

Dentre as diretrizes, pode-se destacar:

A promoção de práticas alimentares saudáveis e a prevenção e o controle dos distúrbios nutricionais e doenças associadas à alimentação e nutrição, o monitoramento da situação alimentar e nutricional, a garantia da qualidade 
dos alimentos colocados para consumo no País, o desenvolvimento de pesquisas e recursos humanos, bem como o estímulo às ações intersetoriais que propiciem o acesso universal aos alimentos (BRASIL, 2006, p. 16).

Um dos pontos salientados pelo PNAN é que, embora as consequências da má nutrição recaiam sobre o setor da saúde, o direito à alimentação adequada a toda a população “[...] é uma responsabilidade a ser compartilhada por todos os setores governamentais e pela sociedade como um todo" (COSTA, 2011, p. 105). A estratégia do PNAN inclui "iniciativas de articulação intersetorial, regulamentação, informação, comunicação e capacitação de profissionais.” (BRASIL, 2006, p. 17). 